\title{
ALGUNS PARÂMETROS DE DESEMPENHO OPERACIONAL DE UM SISTEMA DE RECOLHIMENTO DE PALHIÇO DE CANA-DE- AÇÚCAR (Saccharum spp.) A GRANEL
}

\section{FABIANA NICOLETI FRANCO}

\begin{abstract}
Dissertação apresentada à Escola Superior de Agricultura "Luiz de Queiroz", Universidade de São Paulo, para obtenção do título de Mestre em Agronomia, Área de Concentração: Máquinas Agrícolas.
\end{abstract}

P I R A C I C A B A

Estado de São Paulo - Brasil

Dezembro - 2003 


\title{
ALGUNS PARÂMETROS DE DESEMPENHO OPERACIONAL DE UM SISTEMA DE RECOLHIMENTO DE PALHIÇO DE CANA-DE- AÇÚCAR (Saccharum spp.) A GRANEL
}

\author{
FABIANA NICOLETI FRANCO \\ Engenheira Agrônoma
}

Orientador: Prof. Dr. TOMAZ CAETANO CANNAVAM RIPOLI

Dissertação apresentada à Escola Superior de Agricultura "Luiz de Queiroz", Universidade de São Paulo, para obtenção do título de Mestre em Agronomia, Área de Concentração: Máquinas Agrícolas.

P I R A C I C A B A

Estado de São Paulo - Brasil

Dezembro - 2003 
Dados Internacionais de Catalogação na Publicação (CIP) DIVISÃO DE BIBLIOTECA E DOCUMENTAÇÃO - ESALQ/USP

Franco, Fabiana Nicoleti

Alguns parametros de desempenho operacional de um sistema de recolhimento de palhiço de cana-de-açúcar (Saccharum spp.)a granel / Fabiana Nicoleti Franco. . . Piracicaba, 2003.

113 p. : il.

Dissertação (mestrado) -. Escola Superior de Agricultura Luiz de Queiroz, 2004. Bibliografia.

1. Càna-de-açúcar 2. Colhęita mecânica 3. Desempenho operacional 4. Palhiço I. Titulo

CDD 633.61

"Permitida a cópia total ou parcial deste documento, desde que citada a fonte - $O$ autor" 


\section{DEDICO}

Aos meus pais, Paulo e Marilene (in memorian). Onde quer que estejam, sei que estão orgulhosos.

Aos meus avós, Oswaldo e Thereza e meus tios, Luis Eduardo e Mirtes Volpato. Meus pais de coração...Pelo carinho, amor e apoio incondicional em todas as etapas de minha vida.

Ao meus irmão, Paulo Júnior e minha sobrinha Yasmin...

As minhas "irmãzinhas" queridas, Daphne e Dunaway, amigas e companheiras de todas as horas.

À Tomaz Caetano Cannavan Ripoli e Godofredo César Vitti. Além de professores, meus amigos queridos, que sempre acreditaram em mim.

\section{OFEREÇO}

À Jorge Murilo Suguisawa. Esta dissertação também é sua... 


\section{AGRADECIMENTOS}

Ao meu orientador, Tomaz Caetano Cannavan Ripoli, por demonstrar tanta confiança e amizade.

Aos professores Walter Molina Junior, José Paulo Molin e Marcos Milan, pelos conhecimentos adquiridos durante o curso.

À professora Sonia Stefano Piedade, cuja ajuda foi imprescindível nas análises estatísticas .

Aos amigos e colegas de mestrado que colaboraram para a realização deste projeto e que tornaram nossos dias na salinha mais divertidos: Rodrigo Jacob, Marco Lorenzo Cunalli Ripoli e Thiago Libório Romanelli, Raphael Romanelli, André Pincelli, Alisson Santos, Rui Cosentino e Rodrigo Bonatto.

Aos meus eternos amigos Ana Helena de Felício, Juliano Crivelenti Garcia Leal e Marília Machado Crestana Cantarelli, pelo apoio incondicional, pelas dicas sempre necessárias e pelo enorme carinho.

Ao Grupo Cosan, na pessoa de seus funcionários e colaboradores, que tornaram possível a realização do experimento no campo.

À Deus e minha família... 


\section{SUMÁRIO}

\begin{tabular}{|c|c|c|}
\hline & & \\
\hline ST & TABELAS. & ix \\
\hline RESL & 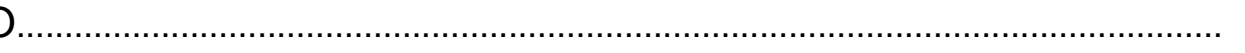 & \\
\hline SUMn & & xii \\
\hline 1 & INTRODUÇÃO... & \\
\hline 2 & REVISÃO BIBLIOGRÁFICA... & 2 \\
\hline 2.1 & Importância econômica............. & 2 \\
\hline 2.2 & 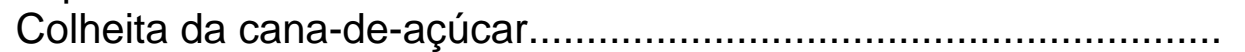 & 3 \\
\hline 2.3 & 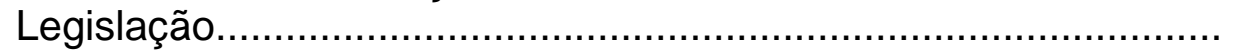 & 6 \\
\hline 2.4 & Colheita sem queima prévia & 7 \\
\hline 2.5 & Palhiço.... & 12 \\
\hline 2.5 .1 & Efeitos do palhiço sobre características químicas e físicas do & \\
\hline & Solo............... & 13 \\
\hline 2.5 .2 & Efeitos do palhiço sobre plantas daninhas.. & 15 \\
\hline 2.5 .3 & Utilização do palhiço como fonte de energia.. & 17 \\
\hline 2.6 & Recolhimento do palhiço............................. & 21 \\
\hline 2.6 .1 & Custos do recolhimento do palhiço... & 22 \\
\hline 2.6 .2 & Terra contida no palhiço..................... & 23 \\
\hline 2.6 .3 & Enfardamento do palhiço & 24 \\
\hline 2.6 .4 & Recolhimento a granel de palhiço..... & 25 \\
\hline 3 & DESEMPENHO OPERACIONAL DE DOIS DIFERENTES & \\
\hline & ENLEIRADORES OPERANDO SOBRE PALHIÇO DE CANA-DE- & \\
\hline & AÇÚCAR & 28 \\
\hline 3.1 & Introdução............ & 28 \\
\hline 3.2 & Material e métodos... & 29 \\
\hline 3.2 .1 & Material..................... & 29 \\
\hline 3.2 .2 & (1) & 30 \\
\hline 3.3 & Resultados e discussão.. & 36 \\
\hline 3.3.1 & Caracterização das condições de solo. & 36 \\
\hline 3.3.2 & 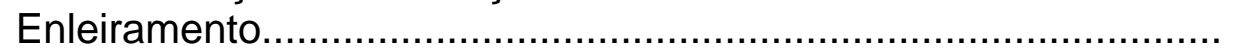 & 37 \\
\hline 3.4 & Conclusões. & 45 \\
\hline 4 & COLHEDORA $\quad$ AUTOPROPELIDA $\quad$ OPERANDO & \\
\hline & PALHIÇO DE CANA-DE-AÇÚCAR SEM QUEIMA PRÉVIA: & \\
\hline
\end{tabular}




\section{RESULTADOS DE ALGUNS PARÂMETROS DE} DESEMPENHO OPERACIONAL............................................... 46

4.1 Introdução........................................................................ 46

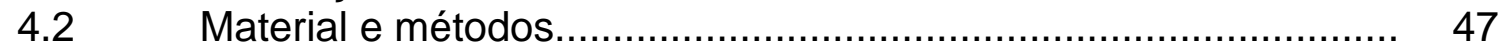

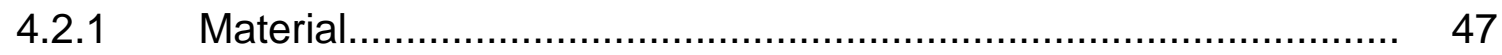

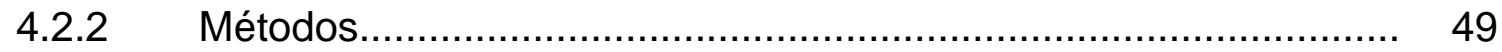

$4.3 \quad$ Resultados e discussão....................................................... 58

4.3.1 Produtividade do palhiço...................................................... 59

4.3.2 Palhiço remanescente ........................................................... 61

4.3.3 Velocidade de deslocamento da recolhedora............................. 62

4.3.4 Capacidade efetiva e operacional da recolhedora e eficiência de campo......

4.3.5 Consumo operacional e efetivo da recolhedora........................... 64

4.3.6 Percentagem de terra no palhiço remanescente........................... 66

4.3.7 Custo do recolhimento......................................................... 67

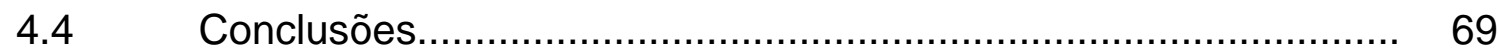

5 CARACTERIZAÇÃO DO PALHIÇO DE CANA-DE-AÇÚCAR COLHIDO E POSTO NA USINA............................................ 70

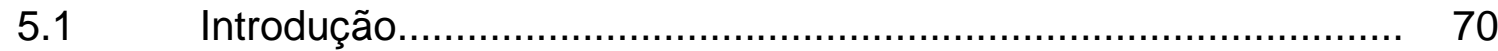

$5.2 \quad$ Material e métodos.......................................................... 71

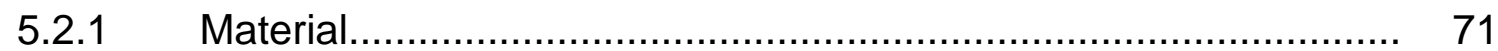

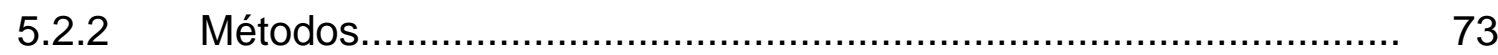

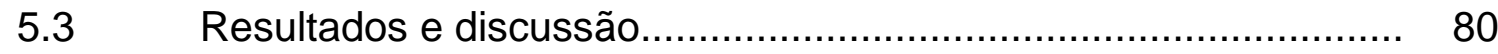

5.3.1 Palhiço recolhido................................................................. 82

5.3.2 Percentagem de terra no palhiço recolhido................................ 84

5.3.3 Umidade do palhiço recolhido................................................. 86

5.3.4 Eficácia de manipulação........................................................ 87

5.3.5 Palhiço transportado por carga (úmido e seco).......................... 88

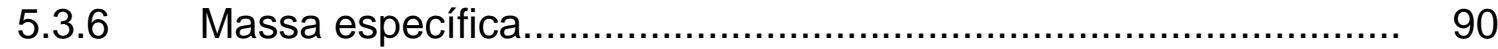

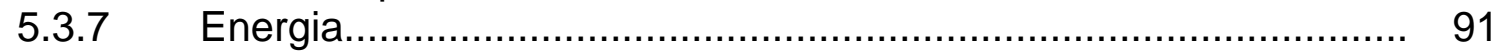

5.3.8 Custo de transporte.............................................................. 92

5.3.9 Custo de descarregamento..................................................... 93

5.3.10 Custo total do palhiço posto na usina.......................................... 93

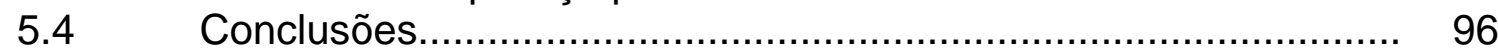

$6 \quad$ CONCLUSÕES GERAIS ..................................................... 97

REFERÊNCIAS BIBLIOGRÁFICAS ..................................................... 98

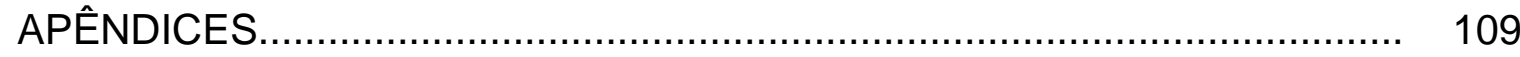




\section{LISTA DE FIGURAS}

\begin{tabular}{|c|c|}
\hline & Alternativas para a queima dos canaviais. \\
\hline 2 & Origem da energia contida em 1 ha de canavial. \\
\hline 3 & 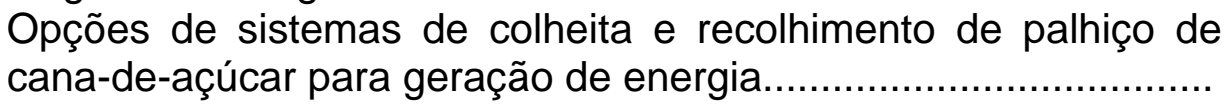 \\
\hline 4 & 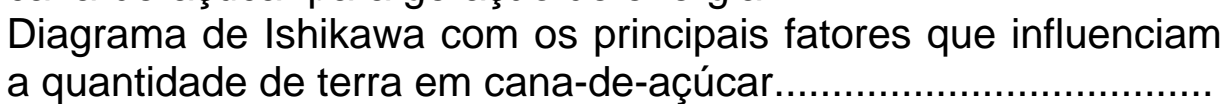 \\
\hline b & $\begin{array}{l}\text { Esquema representando o ciclo operacional (repetição) da } \\
\text { operação de enleiramento }\end{array}$ \\
\hline & 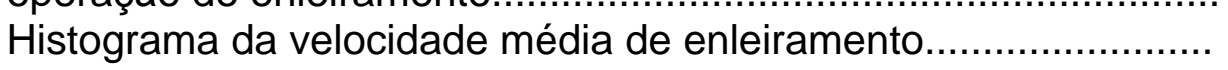 \\
\hline & Capacidade Efetiva, Operacional e Eficiência de C \\
\hline & Histograma do Consumo Efetivo de combustível no enleiramento. \\
\hline
\end{tabular}

9 Histograma do Consumo Operacional de combustível no enleiramento.

Fluxograma das determinações de palhiço remanescente seco sem terra, umidade e terra

Produtividade do palhiço - comparação relativa entre estudos. Histograma da produtividade do palhiço na área experimental...... Comparação entre palhiço remanescente úmido com terra e palhiço remanescente seco sem terra para tratamento.....

Histogramas do Consumo Operacional de combustível na operação de recolhimento

Histogramas de Consumo Efetivo de combustível no recolhimento. 
22 Percentagem de terra no palhiço recolhido (\%)

85

23 Percentagem de terra no palhiço recolhido - comparação entre diversos autores...

25 Comparação entre palhiço total, palhiço recolhido, palhiço remanescente e eficácia de manipulação

26 Comparação entre palhiço recolhido úmido com terra por carga e palhiço recolhido seco sem terra por carga............................ 89

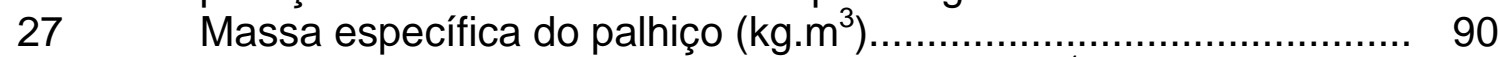

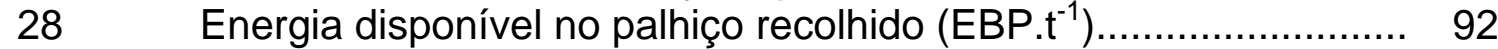

29 Custo total do palhiço - comparação relativa entre diversos

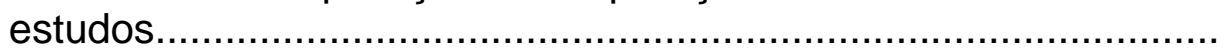




\section{LISTA DE TABELAS}

1 Evolução da área de colheita mecanizada de cana-de-açúcar no Brasil................................................................................ 5

2 Participação da cana sem queima prévia na área de colheita 5 mecanizada no Brasil.

3 Produtividades do palhiço encontradas em bibliografia consultada.

Oferta interna de energia, em percentagem, de 1940 a 1996.

Estimativa do potencial disponível em um hectare de cana-deaçúcar sem queima prévia.

Resultados obtidos por Lopez (1987) sobre operações agrícolas envolvidas na manipulação de palhiço.......................................... 26

Umidade do solo antes da operação de enleiramento......................

Granulometria do solo............................................................. 36

Análise da variância para umidade do solo......

Resumo estatístico da operação de enleiramento........................ 37 enleirado, considerando-se a umidade do material...

Resumo estatístico da operação de recolhimento de palhiço de cana-de-açúcar à granel..... unidades. 


\title{
ALGUNS PARÂMETROS DE DESEMPENHO OPERACIONAL DE UM SISTEMA DE RECOLHIMENTO DE PALHIÇO DE CANA-DE- AÇÚCAR (Saccharum spp.) A GRANEL
}

\author{
Autora: FABIANA NICOLETI FRANCO \\ Orientador: TOMAZ CAETANO CANNAVAN RIPOLI
}

\section{RESUMO}

O presente trabalho teve como objetivos estudar o desempenho operacional dos equipamentos utilizados num sistema de enleiramento e recolhimento de palhiço de cana-de-açúcar colhida mecanicamente, sem queima prévia. O experimento foi desenvolvido em área pertencente ao Grupo COSAN, Usina Costa Pinto. Foi adotado o delineamento inteiramente casualizado para avaliar os dois diferentes tratamentos adotados neste estudo. Com o intuito de facilitar o entendimento das variáveis consideradas, estas foram agrupadas em três capítulos. Foram consideradas as variáveis nas operações de enleiramento e recolhimento do palhiço: velocidade de trabalho, capacidade efetiva e operacional, consumo de combustível, eficiência de campo, produtividade e poder calorífico do material, palhiço recolhido e remanescente, massa específica e percentagem de terra no palhiço, energia disponível por hectare, eficácia de manipulação e custos do sistema. Pode-se concluir que a utilização dos diferentes enleiradores não influenciou de maneira significativa as características do palhiço recolhido, nem o desempenho 
operacional da recolhedora. O sistema de recolhimento a granel, sob o ponto de vista operacional, pode ser considerado como uma opção viável no manejo do palhiço de cana-de-açúcar, visando seu recolhimento e utilização na geração de energia.

PALAVRAS-CHAVE: palhiço, cana-de-açúcar, recolhimento. 


\title{
OPERATIONAL ANALYSES OF BARN COLLECTING SYSTEM OF THE SUGARCANE (Saccharum spp.) TRASH:
}

\author{
Author: FABIANA NICOLETI FRANCO \\ Adviser: TOMAZ CAETANO CANNAVAN RIPOLI
}

\section{SUMMARY}

This work had as goal to study the operational performance of equipments used in an rowing and collecting system of the sugarcane trash of the crop harvested mechanically, without being previously burned. The experiment was developed in an area belonged to COSAN Group, Costa Pinto sugar mill. An experimental delineation entirely random was adopted to evaluate two different treatments adopted in this study. Aiming to ease the understanding of the considered variables, these were grouped in three chapters. The considered variables were: work speed, effective and operational capacities, fuel consumption, work efficiency, yield and heat power of the material, collected and remaining sugarcane trash, its density and the dust percentage in it, available energy per hectare, manipulation efficiency and system cost. It could be concluded that the use of different rowers did not affected in a significant manner the sugarcane trash features, nor the operational performance of the collecting machine. The barn collecting system, under the operational point of view, can be considered as an feasible way in the sugarcane trash management aiming its collecting and the use of it in energy generation process.

KEYWORDS: sugarcane trash, sugarcane, collecting. 


\section{INTRODUÇÃO}

A cultura da cana-de-açúcar no Brasil sempre apresentou grande importância econômica e, atualmente ocupa a terceira posição dentre as culturas mais importantes no cenário agrícola mundial (FNP, 2002).

As modificações sofridas pelo setor canavieiro nos últimos anos, como a desregulamentação setorial e a legislação ambiental regulamentando a queima de pré-colheita em canaviais tem exigindo maior competitividade e incorporação de tecnologia, e incluem menores perspectivas de expansão de mercado para os produtos tradicionais (açúcar e álcool) e a questão do manejo do palhiço remanescente sobre o solo.

O palhiço pode alcançar valores de até trinta toneladas por hectare (base em peso úmido), sendo constituído por folhas verdes, folhas secas, ponteiros, colmos e/ou suas frações e terra agregada a estes constituintes (Ripoli et al., 2003), trazendo benefícios ao sistema produtivo, melhorando as características químicas e físicas do solo, controlando plantas infestantes, sendo uma excelente biomassa para uso na cogeração de energia.

Entretanto, para que o palhiço possa ser aproveitado em processos de co-geração de energia torna-se necessário o desenvolvimento de sistemas que viabilizem sua retirada do campo e seu posterior transporte até as usinas, onde seriam queimados isoladamente ou junto ao bagaço.

O objetivo do presente estudo foi o avaliar um sistema de recolhimento do palhiço, à granel, considerando alguns parâmetros de desempenho operacional. A hipótese de trabalho é a de que é viável técnica e operacionalmente, para uso como fonte de energia, a retirada à granel do palhiço de cana-de-açúcar colhida mecanicamente, sem queima prévia. 


\section{REVISÃO BIBLIOGRÁFICA}

\subsection{Importância econômica}

A cana-de-açúcar (Saccharum spp.) é uma espécie vegetal da família das gramíneas, que vem sendo cultivada desde os tempos mais remotos (Leão, 2002). Para Cunha et al. (2001), é uma das gramíneas mais cultivadas nas regiões tropicais e subtropicais, onde o Brasil é o maior produtor mundial e o país com maior potencial de expansão em área plantada.

Na safra 2001/2002 o Brasil produziu mais de trezentos milhões de toneladas de cana-de-açúcar, valor este referente à produção de colmos entregues nas usinas. São Paulo é o maior Estado produtor, responsável por mais de duzentos milhões de toneladas dessa safra, e o agronegócio da canade-açúcar representa 35\% do PIB (Produto Interno Bruto) agrícola paulista (Agrocana, 2003). De acordo com ÚNICA (2002), e Agrianual 2002 (FNP, 2002), a área de cana-de-açúcar colhida no Brasil em 2001, foi da ordem de $4,728 \times 10^{6}$ ha, com uma produção de $282,621 \times 10^{6}$ t e uma produtividade média de 58,3 t.ha ${ }^{-1}$.

Para Nascimento (1999), a cana-de-açúcar ocupa importante papel no cenário agrícola brasileiro desde a época colonial, devido aos variados produtos dela extraídos, como açúcar, álcool, aguardente e resíduos de sua industrialização. Assim, ela é um dos principais produtos agrícolas brasileiros, sendo cultivada desde a época da colonização, sendo o principal tipo de biomassa energética, base para todo o agronegócio sucroalcooleiro, representado por 350 indústrias de açúcar e álcool que geram 1.000.000 de empregos diretos e 300.000 indiretos em todo Brasil (Banco de Dados de Biomassa no Brasil, 2002). 
Luchesi (1995) destaca a utilização do bagaço de cana-de-açúcar para a produção de energia e papel e dos ponteiros na alimentação animal e para extração de palmito, para alimentação humana.

A agroindústria canavieira paulista vem passando por modificações importantes, principalmente em razão da desregulamentação setorial empreendida pelo governo federal a partir de 1990 (Guedes \& Ré, 2002). Segundo estes autores, a nova dinâmica da agroindústria canavieira resultante desse processo de desregulamentação setorial, embora ainda em processo de gestação, permite evidenciar os seguintes aspectos: a redução drástica do papel do Estado enquanto agente planejador e regulador das atividades deste ramo agroindustrial; constituição de um ambiente econômico-institucional mais competitivo, no qual as empresas do setor procuram definir estratégias tanto defensivas quanto ofensivas, sendo propício à incorporação de progresso técnico; perspectivas de expansão de mercado (interno e externo) para seus produtos (açúcar e álcool) são estritas, de maneira que a expansão desta agroindústria não se dará conforme as mesmas taxas dos períodos anteriores; estreitamento do mercado para os produtos tradicionais derivados da cana tem impelido várias empresas a buscarem na diversificação e diferenciação do produto e na integração para frente, o mecanismo para garantir um crescimento sustentável em médio prazo.

\subsection{Colheita da cana-de-açúcar}

A expansão da atividade canavieira foi gradativamente ocorrendo em áreas de grandes atividades sócio-econômicas e alta concentração urbana, ocasionando críticas dos mais variados aspectos, como, por exemplo, nas operações de colheita envolvendo a queima prévia do canavial com danos ao ambiente (Buzolin, 1997). Por este motivo, segundo Nery (2000), a produção de cana-de-açúcar vem sofrendo ajustes no que se refere ao sistema de colheita, onde a queima como prática de pré-colheita gerou uma série de controvérsias nos aspectos energéticos, ambientais e sociais, fazendo com que o governo do 
Estado de São Paulo elaborasse a Lei No 11.241 de 19/09/2002 restringindo a queima como prática auxiliar na operação de colheita.

Segundo Quintela (2001), a queima dos canaviais consiste numa prática comumente adotada em diversos países produtores, pois aumenta 0 desempenho das colheitas manual e mecanizada. É importante destacar que, segundo Ripoli \& Ripoli (1995), abandonando-se essa prática, o palhiço remanescente sobre o terreno e decorrente da colheita mecanizada poderia ser recolhido e utilizado para co-geração de energia elétrica nas próprias usinas e destilarias.

Segundo Pagnano (1997), a exigência que a colheita seja realizada sem que haja agressão ao ambiente tem crescido por parte dos ambientalistas e passou a encontrar respaldo no setor político, na medida em que a mão-deobra disponível no campo, que deseja continuar a exercer a profissão de cortador de cana-de-açúcar, tem diminuído e a demanda por investimento de capital de outros setores tecnológicos exige uma melhor qualidade do ar.

Os objetivos fundamentais da mecanização agrícola, segundo Ripoli \& Mialhe (1987), são aumentar a produtividade da mão-de-obra e reduzir os custos operacionais. A indústria de máquinas agrícolas, de acordo com Orlando Filho et al. (1998), vem, nos últimos anos, desenvolvendo colhedoras de cana, visando adaptá-las a áreas de cana colhida sem queima prévia. A evolução da área de colheita mecanizada no Brasil pode ser visualizada na Tabela 1. 
Tabela 1. Evolução da área de colheita mecanizada de cana-de-açúcar no Brasil

\begin{tabular}{ccccccc}
\hline Anos & $\begin{array}{c}\text { São } \\
\text { Paulo } \\
(\%)\end{array}$ & $\begin{array}{c}\text { Centro } \\
\text { Sul } \\
(\%)\end{array}$ & $\begin{array}{c}\text { Nordeste } \\
(\%)\end{array}$ & $\begin{array}{c}\text { Brasil } \\
(\%)\end{array}$ & $\begin{array}{c}\text { Áreas Totais } \\
\text { Corte } \\
(\times 1000 \text { ha })\end{array}$ & $\begin{array}{c}\text { Áreas } \\
\text { Mecanizadas } \\
(\times 1000 \text { ha })\end{array}$ \\
\hline 1994 & - & - & - & 4,0 & 3.208 & 128,3 \\
1997 & 17,8 & 15,4 & 3,2 & 13,5 & 3.691 & 498,3 \\
1998 & 26,4 & 24,9 & 5,7 & 23,8 & 3.855 & 917,5 \\
1999 & 22,3 & 25,3 & 5,9 & 23,0 & 4.103 & 943,7 \\
2000 & 30,5 & 28,0 & 7,6 & 24,7 & 3.687 & 910,7 \\
2001 & 33,0 & 31,0 & 8,0 & 29,0 & 3.785 & 1097,6 \\
2002 & 35,0 & 32,5 & 9,0 & 31,8 & 4.171 & 1326,4 \\
\hline
\end{tabular}

Adaptado: IDEA, 2002

Na Tabela 2 observa-se a participação da cana sem queima prévia na área de colheita mecanizada no Brasil.

Tabela 2. Participação da cana sem queima prévia na área de colheita mecanizada no Brasil

\begin{tabular}{rcccc}
\hline Anos & $\begin{array}{c}\text { São Paulo } \\
(\%)\end{array}$ & $\begin{array}{c}\text { Centro Sul } \\
(\%)\end{array}$ & $\begin{array}{c}\text { Brasil } \\
(\%)\end{array}$ & $\begin{array}{c}\text { Áreas } \\
(\text { ha })\end{array}$ \\
\hline 1994 & - & - & 0,8 & 1.026 \\
1997 & 21,3 & 21,4 & 20,4 & 101.650 \\
1998 & 40,3 & 35,1 & 33,5 & 307.358 \\
1999 & 42,5 & 34,6 & 34,9 & 329.348 \\
2000 & 42,0 & 44,4 & 40,7 & 370.650 \\
\hline
\end{tabular}

Adaptado: IDEA, 2002 


\subsection{Legislação}

Durante os últimos 50 anos quase toda a área cultivada com cana-deaçúcar no Brasil esteve submetida à queima prévia para facilitar procedimentos de corte e carregamento.

A eliminação da queima da cana-de-açúcar naturalmente implica na utilização da colheita mecanizada. De acordo com Guedes \& Ré (2002), desde 1988 os sucessivos governos estaduais paulistas têm mostrado preocupação em normatizar aspectos vinculados à prática da queima da cana. Por pressão, principalmente dos grupos ambientalistas, mas também pela condenação da opinião pública em geral a essa prática agrícola, foram baixadas leis para sua regulamentação. Assim, estes mesmos autores citam o Decreto $\mathrm{n}^{\circ} 28.848$ de 30/8/1988, que proibiu a queimada da cana em áreas consideradas de preservação ambiental, próximas a redes elétricas, rodovias, ferrovias e próximas ao perímetro urbano.

Em 1997, o Decreto $n^{\circ} 42.056$ de agosto de 1997 inaugurou a legislação ambiental específica para o setor canavieiro, uma vez que regulamenta a prática da queima da cana-de-açúcar. O Decreto impôe que a queima da cana, como método auxiliar a colheita, fica proibida no Estado de São Paulo, e será admitida apenas em caráter excepcional e transitório. Para tanto, estabelece um cronograma, ao fim do qual essa prática deverá estar erradicada nos canaviais (Costa, 2001).

No âmbito federal, Nery (2000) cita o Decreto $n^{\circ} 2.661$ de 08 de julho de 1998, que regulamenta o parágrafo único do artigo 27 da lei $n^{\circ} 4.771$ de 15 de setembro de 1965 (código florestal), mediante o estabelecimento de normas de precaução relativas ao emprego do fogo em práticas agropastoris e florestais, ampliando o prazo das queimadas para 20 anos.

O debate, sob a ótica ambiental, da questão do uso do fogo para a colheita da cana-de-açúcar no Estado de São Paulo, segundo a Revista Gleba (2002), resultou na Lei ${ }^{\circ} 10.547 / 00$, que estabeleceu o plano de queimadas do Estado e inseriu profundas transformações quanto ao uso agrícola do fogo, e 
que foi regulamentada pelo Decreto Lei $n^{\circ} 48.869 / 01$, prevê a eliminação do fogo na colheita da cana no prazo de 20 anos, devendo ser realizada de forma gradativa, em conjunto com políticas de reciclagem e aproveitamento da mãode-obra setor sucroalcooleiro. Recentemente, a Lei $n^{\circ} 11.241$, de 19/09/02 regulamentou a queima em pré-colheita da cana-de-açúcar, determinando sua completa eliminação nos próximos 30 anos.

\subsection{Colheita sem queima prévia}

Caldeira (2002) cita que, com o aumento das áreas produtivas e a crescente preocupação com o ambiente, a colheita mecanizada de cana crua vem substituindo, gradativamente, a colheita manual com queima prévia.

Para De Leon (2000), o sistema de colheita de cana crua é uma opção de exploração da cultura da cana-de-açúcar, viabilizada pelo desenvolvimento de colhedoras que operam satisfatoriamente sob essa condição. Este sistema proporciona melhorias à atividade canavieira, ao ambiente e ao bem estar social. A colheita mecanizada vem se tornando economicamente viável, quando comparada à manual, além do que, a colheita manual, vista do ponto social, é considerada como inaceitável devido ao alto risco de acidentes ocupacionais e ao elevado esforço físico exigido das pessoas que fazem a operação de corte.

Entretanto, como afirmam Ripoli et al. (1995), a implantação do manejo da cana-de-açúcar sem a queima depende da aptidão das terras à colheita mecanizada.

Segundo COPERSUCAR (2001) e Caldeira (2002), a adoção da colheita mecanizada sem queima prévia pode ser considerada recente e do ponto de vista técnico, aspectos favoráveis e desfavoráveis devem ser considerados. Torna-se clara a contribuição da cobertura vegetal proporcionada pelo sistema para o solo, em termos de controle de erosão, retenção de umidade, matocomposição, melhoria nas propriedades biológicas, químicas e físicas oriundas da decomposição da palhiço na superfície do solo. 
Como vantagens ecológicas da colheita de cana crua, Pagnano (1997) apresenta a redução da emissão de $\mathrm{CO}_{2}$ para a atmosfera, eliminação de fumaça e fuligem que prejudicam a saúde do homem, e a interrupção no fornecimento de energia elétrica causadas por queimadas próximas a rede de transmissão.

Entretanto, Caldeira (2002) afirma que alguns problemas estão relacionados à presença da palhiço no campo, tais como o possível retardamento na brotação devido a menor incidência de luz, aliada à diminuição da temperatura do solo e aumento da umidade com conseqüente proliferação de doenças; a imobilização de nutrientes minerais, principalmente o nitrogênio, podendo afetar a produtividade da cultura; as dificuldades na operação das máquinas para realização de tratos culturais; problemas operacionais causando perdas e injúrias da soqueira, entre outros.

Além disso, Miranda (2000) afirma que em áreas de colheita de cana sem a queima prévia, ou cana crua, as populações de Mahanarva fimbriolata, conhecida como cigarrinha das raízes, vêm se elevando, significativamente, causando sérios danos à cultura. Segundo a autora, ambientes quentes e úmidos favorecem o desenvolvimento das cigarrinhas, razão pela qual o incremento das áreas da colheita mecanizada de cana crua tem contribuído para o aumento de suas populações, uma vez que as condições proporcionadas pela abundante cobertura vegetal deixada no solo são bastante favoráveis a essa praga. Além disso, a despalha da cana a fogo, antes da colheita, contribuía para a destruição de todas as formas biológicas da praga. Ainda, segundo Miranda (2000), além da perda de produtividade agrícola, as cigarrinhas provocam uma redução significativa na qualidade da matéria-prima, pois ocorre uma diminuição de açúcares e aumento da quantidade de fibra devido ao secamento dos colmos.

Além da maior incidência de cigarrinha das raízes, a não queima dos canaviais pode trazer aumento da população de outras pragas. Segundo Degaspari et al. (1973), a queima da cana ajuda no controle da broca da cana 
(Diatraea saccharalis) reduzindo drasticamente sua população sem, contudo, diminuir os seus inimigos naturais na mesma proporção.

Segundo Santaella (1995), diversas alternativas vem sendo estudadas visando aproveitar a massa vegetal que deixa de ser queimada no sistema de cana crua. Um esquema simplificado das possíveis alternativas para utilização do palhiço é apresentado na Figura 1.

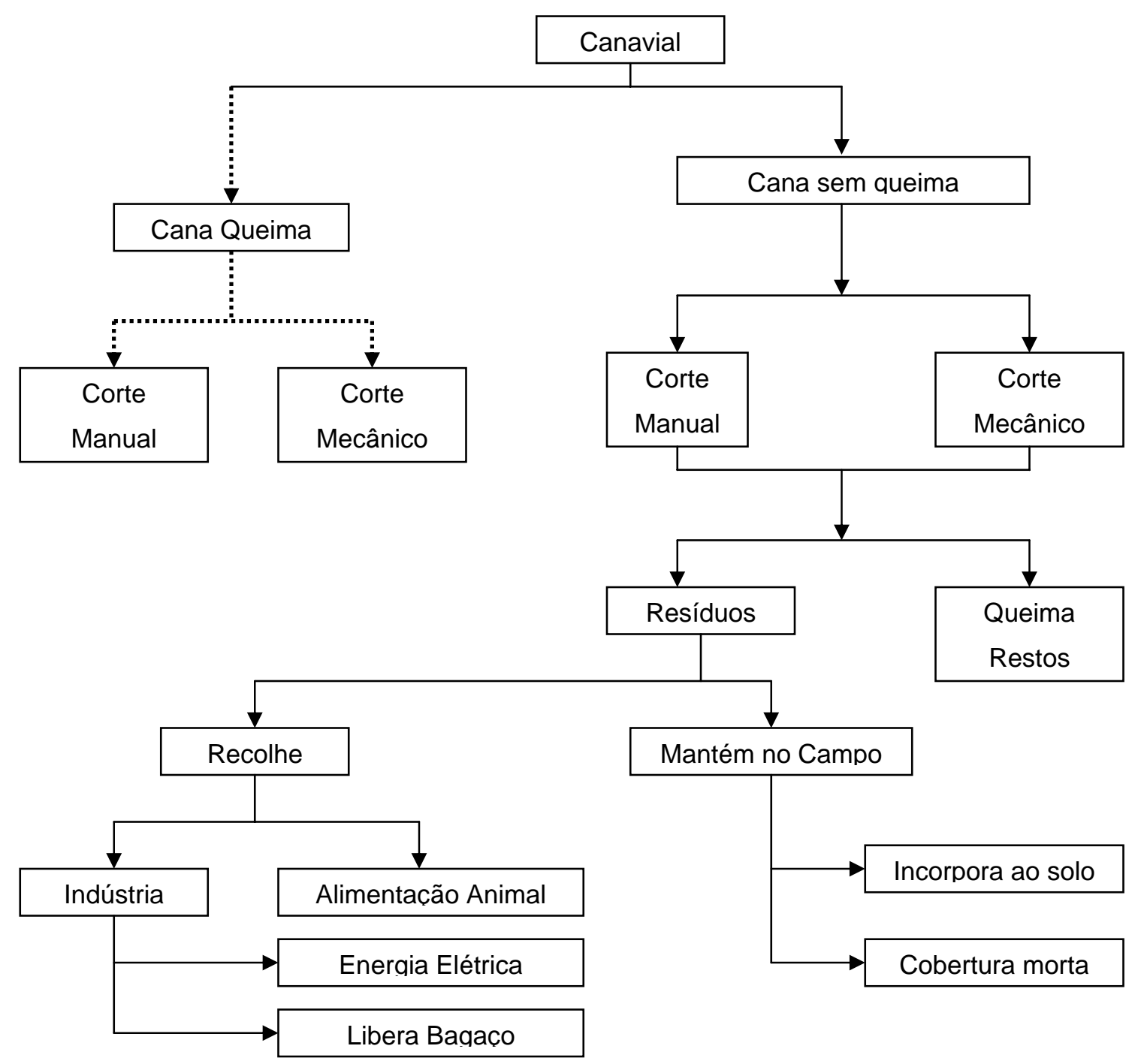

Figura 1 - Alternativas para a queima dos canaviais (Santaella, 1995) 
Ripoli \& Villa Nova (1992) citam que um dos principais desafios a serem enfrentados no sistema de colheita mecânica de cana crua é o domínio da utilização do palhiço sobre o terreno, pois, muitos problemas ainda são detectados com relação às práticas provenientes do corte de cana crua, como ataques de insetos, doenças, perigo de incêndio no palhiço, aumento de matéria estranha vegetal, maior volume de matéria-prima esmagada, corte basal mais elevado, alterações em equipamentos, além de maior custo com implantação de uma nova tecnologia.

Abramo Filho et al. (1993), estudaram os resíduos da colheita mecanizada de cana crua e encontraram $21,3 \mathrm{t}$.ha ${ }^{-1}$ de palhiço, com umidade de $22,34 \%$ e 6,92\% de terra junto ao palhiço. Os mesmos autores afirmam que a quantidade de palhiço deixado no campo oscila de 13 a 20t.ha ${ }^{-1}$ de matéria seca (MS) e é diferente para cada variedade, apresentando vantagens e desvantagens agronômicas. Já Urquiaga et al. (1997) comentam que a queima desse material representa uma perda de vários nutrientes, principalmente de nitrogênio e enxofre.

Molina Junior et al. (1995) encontraram, para a variedade SP 706163 (em segundo e terceiro cortes), no momento da colheita, valores de 33,85 (+/$9,83)$ t.ha-1 de palhiço.

De acordo com Sartori (2001), existe uma grande variação na quantidade de resíduos resultantes da colheita da cana-de-açúcar sem queima prévia, indo de 6,0 t.ha ${ }^{-1}$ a 22,8t.ha ${ }^{-1}$ de palhiço, variação esta decorrente da variedade plantada, idade da planta e condições edafoclimáticas.

Ripoli (2002), ao estudar o mapeamento de palhiço enfardado de cana-de-açúcar, concluiu que sua variabilidade espacial é muito grande, encontrando valores que variaram de 4,74 a 14,56t.ha ${ }^{-1}$, com umidade também bastante variável (11,1 a 39,6\%), alertando ainda que maiores cuidados nas amostragens e determinação da produtividade deste material, devem ser observados. 
Com a colheita sem queima da cana-de-açúcar, de acordo com De Luca (2002), a cada ano é depositada uma quantidade próxima de 15 t.ha ${ }^{-1}$ de material vegetal seco, que começa imediatamente a proteger o solo contra agentes físicos causadores de sua deterioração, como águas de chuvas e curtos ciclos de umidade e temperatura extremas. Ao longo do ciclo da cultura, parte do material depositado a cada ano, que seria lançado na atmosfera na forma de gases poluentes, pode ser incorporado ao solo durante o fenômeno da decomposição.

Ripoli (2002) afirma que a cultura canavieira pode gerar biomassa da ordem de 15 a 30\% em peso da parte aérea das plantas, dependendo das condições de campo (variedade, idade, número de cortes e condições edafoclimáticas). Na Tabela 3, estão apresentados dados sobre produtividade do palhiço obtidos em bibliografia.

Tabela 3. Produtividades do palhiço encontradas em bibliografia consultada

\section{Autores}

Ripoli et al. (1990)

Ripoli et al. (1991)

Abramo Filho et al. (1993)

Molina Jr et al. (1995)

Ripoli et al. (1995)

Ripoli et al. (1995)

Furlani Neto et al. (1996)

Furlani Neto et al. (1996)

Ripoli et al. (1999)

Sartori (2001) Produtividade do Palhiço (t.ha ${ }^{-1}$ ) 


\subsection{Palhiço}

Segundo Hiler \& Stout (1985) biomassa é toda matéria orgânica com a exceção dos combustíveis fósseis. A biomassa para combustível inclui resíduos agrícolas, culturas para uso como combustível, subprodutos do processamento de alimentos, resíduos florestais e lixo urbano.

Para Brito (1986), a biomassa pode constituir a base de um modelo de desenvolvimento tecnológico e industrial auto-sustentado, baseado em dados conceitos da realidade regional e na integração do homem a um ambiente econômico em harmonia com o seu ambiente, além de ser uma fonte simples de energia alternativa.

A denominação genérica e errônea para o resíduo da colheita de cana-de-açúcar, sem queima prévia, segundo Ripoli et al. (2003), tem sido "palha", quando o correto tecnicamente seria "palhiço", porque tal material não se constitui apenas de folhas de cana com baixo grau de umidade. Ripoli (1991), define o palhiço como sendo constituído de folhas verdes, palhas, ponteiros, colmos ou suas frações, rebolos ou suas frações, com terra a eles agregados.

Para Ripoli (2001), esta matéria-prima desperta o interesse dos canavieiros, uma vez que o equivalente energético do palhiço gira em torno de 1,2 barris de petróleo por tonelada de material. Esse palhiço é encontrado nos canaviais na ordem de 9 a 32t.ha ${ }^{-1}$ com base em peso úmido. Ou seja, dependendo das condições da cultura, um hectare de canavial oferece entre 11 e 33 equivalentes barris de petróleo. Esta variabilidade é, segundo Sartori (2001), decorrente da variedade plantada, idade da planta e condições edafoclimáticas. Para Torresan (2003), essa variabilidade oriunda de fatores como as diferentes características das variedades utilizadas, as diferenças metodológicas adotadas em cada experimento e também o tempo decorrido entre a colheita mecanizada e a coleta das amostras.

Para Ripoli (1990), o palhiço remanescente da colheita sem queima prévia ainda é pouco utilizado na co-geração de energia pelas usinas, devido, 
principalmente, a ausência de tecnologias que viabilizem o processo de retirada do campo e ao elevado custo de transporte, uma vez que ocupa grande volume, dependendo do sistema utilizado.

\subsubsection{Efeitos do palhiço sobre características físicas e químicas do solo}

Para Suguitani et al. (2001), a manutenção da produtividade dos agroecossistemas depende do manejo dado ao solo e dentre os principais aspectos a serem observados estão o processo de transformação da matéria orgânica e a atividade da biomassa microbiana.

Define-se como matéria orgânica, segundo Kiehl (1979), os materiais vegetais ou animais em fase de decomposição ou humificados que sofreram processo de decomposição biológica através de microorganismos. As principais fontes de matéria orgânica são as plantas, pela deposição de ramos, folhas e raízes encontrados em diferentes estádios de decomposição.

A degradação de um material orgânico depende do tipo, qualidade e quantidade adicionada ao solo, os quais poderão modificar a estrutura, capacidade de retenção de água, consistência, densidade, porosidade, aeração e condutividade elétrica do mesmo. Desta forma, Orlando Filho et al. (1998), afirmam que os acúmulos de palhiço, por vários anos, nas áreas cultivadas com cana-de-açúcar, contribuem como fonte de matéria orgânica, servindo como alimento para os organismos ali presentes, proporcionando a manutenção da produtividade da cultura.

Em relação à física do solo, Abramo Filho et al. (1993) e Orlando Filho et al. (1998) afirmam que em solos com maior cobertura vegetal ocorre maior capacidade de retenção de água, proporcionando maior manutenção de umidade, responsável por grande parte das propriedades físicas, químicas e biológicas do solo. Já Timm (2002), concluiu que a troca da prática da queima da cultura de cana-de-açúcar antes da colheita para a prática de deixar o palhiço como cobertura vegetal da superfície do solo não afetou nenhum dos seguintes componentes do balanço hídrico: escoamento superficial, fluxo de 
água no solo no limite inferior do volume de solo em estudo e o armazenamento de água no solo. No mesmo estudo, o autor concluiu que a presença da cobertura vegetal na superfície do solo na cultura de cana de açúcar pode reduzir as temperaturas médias na superfície do solo na ordem de $7^{\circ} \mathrm{C}$, evitando picos de temperatura na superfície durante o período inicial da cana soca. A cobertura vegetal, contudo, afetou negativamente o desenvolvimento da cultura reduzindo o número de colmos e seu peso úmido, em torno de $13 \%$.

Abramo Filho et al. (1993) estudaram os resíduos da colheita mecanizada de cana crua e encontraram uma camada de 8 a $10 \mathrm{~cm}$ de palhiço fazendo com que a temperatura do solo fosse $5^{\circ} \mathrm{C}$ mais baixa que a ambiente. Os autores comentam que as massas de resíduos resultantes da colheita da cana dependem de uma série de condições intrínsecas à colhedora, à cultura e ao manejo da mesma.

De acordo com COPERSUCAR (2001), estudos mostraram que a única maneira eficaz de evitar a erosão hídrica nas áreas agricultáveis é impedir o seu início, utilizando técnicas que evitem o impacto direto das gotas de chuva sobre a superfície do solo. O autor recomenda manter o solo coberto por meio de material orgânico, protegendo-o das intempéries, especialmente durante as reformas dos canaviais, utilizando-se de adubação verde e de rotação com leguminosas e a adoção de sistema de preparo do solo onde se realiza o mínimo de operações motomecanizadas e na época correta. O manejo conservacionista de solos viabiliza, tecnicamente, o preparo reduzido em áreas de cana sem queimar com excesso de palhiço e, ainda, propicia redução de custos da ordem de $30 \%$ quando comparado ao uso de grade e subsolador convencional.

Apesar das visíveis vantagens quanto ao aspecto ambiental, a grande quantidade de palhiço sobre o terreno de cultivo acaba por interferir e dificultar os tratos culturais pós-colheita (Carvalho, 1996). 


\subsubsection{Efeitos do palhiço sobre plantas daninhas}

A cana-de-açúcar é cultivada, atualmente, nas mais diversas condições de solo e clima, o que acaba por determinar diferentes graus de competição entre a cultura e as plantas daninhas. A pressão de seleção neste agrossistema, segundo Christoffoleti (1997), leva a diminuição, ou até mesmo a eliminação dos indivíduos mais vulneráveis. O autor afirma que as plantas daninhas crescem junto com as culturas, interferindo no desenvolvimento e manejo, reduzindo a produção pela competição por água, luz, gás carbônico, nutrientes e também pela inibição alelopática, além dos prejuízos ocasionados por pragas e doenças que utilizam as plantas daninhas como hospedeiras, antes de se alojarem nas culturas. Elevadas densidades plantas daninhas desde as fases iniciais da cultura interferem na produtividade de maneira tão intensa que o controle se torna indispensável.

Lorenzi (1986) comenta que o controle das invasoras chega a representar 35 a 45\% dos custos de implantação e condução do canavial.

Para Arevalo \& Bertoncini (1999), o palhiço sobre a soqueira de canade-açúcar possibilita um melhor domínio das plantas daninhas, pois os resíduos da colheita chegam a controlar mais de $50 \%$ das matoespécies que infestam a cultura devido aos efeitos físicos e bioquímicos da palhiço sobre o mato.

Segundo a COPERSUCAR (2001), a quantidade de palhiço suficiente para um controle de plantas daninhas foi da ordem de 7,5 a 9,0t.ha ${ }^{-1}$ (matéria seca), quando uniformemente distribuídas sobre o solo. Nessas condições, a eficiência de controle, foi considerada igual ou maior do que a que se consegue por meio de aplicações bem sucedidas de herbicidas.

Lorenzi (1984) define alelopatia como qualquer efeito causado por uma planta ou microorganismos que direta ou indiretamente é prejudicial a outro individuo, por meio da liberação de compostos químicos ao ambiente.

Gomide (1993) afirma que o palhiço proporciona maior controle da plantas daninhas por liberar aleloquímicos, além de atuar como barreira física e impedir a incidência de luz inibindo suas emergências, sendo que o controle 
alelopático das plantas daninhas constitui uma opção a ser somada aos diversos tipos existentes, auxiliando inclusive na redução do uso de herbicidas e diminuindo os custos com o controle das mesmas. Para Lorenzi (1984) a utilização da cobertura verde ou morta dos restos vegetais no controle das plantas daninhas é atribuída não apenas a ação do impedimento físico da camada vegetal ou a impossibilidade da passagem de luz, prejudicando a germinação das sementes de outras plantas, mas também a alelopatia sobre outras plantas daninhas ou mesmo cultivadas.

Carvalho (1996) e Campos \& Marconato (1994), afirmam que, em áreas de colheita de cana crua, a brotação inicial da soqueira normalmente é retardada, devido aos efeitos de sombreamento e barreira física ocasionados pela cobertura morta. Porém, decorrido o ciclo da cultura, a quantidade de perfilhos nestas áreas é praticamente a mesma de quando se cultiva o canavial de maneira tradicional.

Avaliando os efeitos dos restos culturais da colheita de cana-deaçúcar na incidência de plantas daninhas e na produtividade da soqueira, Andrade et al. (1999), observaram que os resíduos triturados proporcionaram uma diminuição na quantidade de plantas infestantes.

Quintela (2001) afirma que a inibição alelopática pode manifestar-se tanto das plantas daninhas com relação à cana-de-açúcar como também ao contrário, já que alguns poucos centímetros de palha de cana são capazes de inibir a germinação de sementes de plantas daninhas. Lorenzi (1984), afirma que por meio da ação alelopática alguns centímetros de palha da cana impedem a germinação de tiririca (Cyperus rotundus).

Também Quintela (2001) observou em seu estudo sobre controle de plantas daninhas e produtividade de cana crua no sistema integrado palhiço, herbicida e vinhaça, que nos tratamentos de cobertura com palhiço houve efeito de barreira física e alelopática no controle de grama seda, tiririca e braquiária. 


\subsubsection{Utilização do palhiço como fonte de energia}

O mundo contemporâneo apresenta, segundo Faccenda \& Souza (1998), uma situação bastante crítica no que se refere à geração de energia elétrica. A crescente demanda, com as respectivas conseqüências, aponta para um futuro incerto a todos os povos. Também Sarriés (1997) afirma que existem estatísticas alarmantes sobre a oferta e a demanda de energia elétrica no Brasil. Para contornar esse problema, uma alternativa é a co-geração de energia elétrica a partir de resíduos de processos agro-industriais.

No início da década de 40, segundo Patusco (2002), a biomassa era responsável por cerca de $83 \%$ da oferta interna de energia do Brasil, dos quais $81 \%$ correspondentes a lenha e $2 \%$ ao bagaço de cana, tendo, no entanto, sua participação diminuída com o uso crescente dos derivados de petróleo. A evolução da oferta interna de energia no Brasil pode ser observada na Tabela 4.

Tabela 4. Oferta interna de energia, em percentagem, de 1940 a 1996

\begin{tabular}{lccc}
\hline \multicolumn{1}{c}{ Fontes } & \multicolumn{3}{c}{ Oferta Interna de Energia (\%) } \\
& 1940 & 1970 & 1996 \\
\hline Petróleo e Gás Natural & 6,1 & 33,3 & 35,2 \\
Carvão mineral & 6,2 & 3,6 & 5,2 \\
Hidráulica & 4,9 & 15,8 & 38,3 \\
Lenha & 80,5 & 42,6 & 9,6 \\
Produtos da cana & 2,3 & 4,7 & 10,2 \\
Outras & 0,0 & 0,0 & 1,6 \\
\hline
\end{tabular}

Adaptado: Patusco, 2002

Na década de 90 e, principalmente, após o Plano Real, iniciou-se, segundo Bartholomeu et al. (2001), um processo de reestruturação do setor de energia elétrica, devido, por um lado, ao crescimento da demanda por eletricidade e, por outro, à dificuldade de financiamentos de novos 
investimentos e a problemas de eficiência econômica. Assim, o processo de reestruturação promoveu a separação das atividades de geração, transmissão, distribuição e comercialização, onde a geração e a comercialização tornaram-se competitivas, enquanto que a transmissão e distribuição foram mantidas sob monopólios regulados. Este cenário, segundo os mesmos autores, tem incentivado a geração de energia elétrica por meio de biomassa, como o bagaço de cana.

O processo de co-geração, segundo Coelho (2001), corresponde à geração de energia térmica e mecânica, a partir de uma mesma fonte primária de energia. A energia mecânica pode ser utilizada na forma de trabalho, como o acionamento das moendas numa usina de açúcar e álcool ou transformada em energia elétrica por meio de geradores de eletricidade. Segundo o autor, o combustível utilizado no processo de co-geração poder ser petróleo, gás natural, carvão ou biomassa. Lanças (1984), discorreu sobre a evolução da utilização das alternativas energéticas, citando vantagens da utilização de biomassa em larga escala: recursos abundantes, renováveis e disponíveis em diversas formas e grande variedade de uso; produção descentralizada; redução da poluição ambiental em relação aos combustíveis fósseis.

Segundo Agropecuária Agora (2002), a co-geração de energia consiste no aproveitamento do vapor pela queima de biomassa para movimentar os equipamentos da usina de cana e, simultaneamente, gerar energia elétrica para o consumo próprio, possibilitando, também, a comercialização do excedente com as distribuidoras e concessionárias do setor elétrico, transformando-se, assim, em fonte de renda para a indústria sucroalcooleira.

O poder calorífico de materiais vegetais pode ser considerado segundo Brito \& Barrichelo (1982), de duas maneiras: superior (PCS), quando é considerado o calor liberado pela condensação da água de constituição do combustível; inferior ( $\mathrm{PCl})$, quando esta consideração não é feita. Os mesmos autores afirmam que na prática o $(\mathrm{PCl})$ deve ser o preferido, apesar de, no 
processo de determinação do poder calorífico, geralmente utilizar-se da bomba calorimétrica, a qual fornece o poder calorífico superior (PCS). Para se contornar a situação lança-se mão da relação entre PCS e $\mathrm{PCl}$, regida pela quantidade de hidrogênio contida no combustível e descontando-se o calor de vaporização da água formada no processo, conforme a Equação 1 apresentada por Doat (1977).

$$
P C I=P C S-\left[600 \times 9 \times\left(\frac{H}{100}\right)\right]
$$

Sendo:

$\mathrm{PCl}\left(\mathrm{kcal}^{\mathrm{kg}} \mathrm{kg}^{-1}\right)=$ Poder Calorífico Inferior (com base em peso úmido). $\mathrm{PCS}\left(\mathrm{kcal} . \mathrm{kg}^{-1}\right)=$ Poder Calorífico Superior (com base em peso seco). $H(\%)=$ teor de hidrogênio no material. 600 = valor médio (kcal) de energia absorvida por quilograma de água para se atingir a temperatura de evaporação.

9 = múltiplo do peso do hidrogênio contido no combustível, que fornece o peso da água durante a combustão.

Doat (1977), apresenta também a Equação 2 que fornece valor bastante aproximado do Poder Calorífico Útil (PCU) de madeiras, ou seja, fornece o Poder Calorífico Inferior ( $\mathrm{PCl}$ ) com base em peso úmido, deduzindose a energia consumida na evaporação da água de formação.

$$
P C U=P C I \times\left[\frac{(100-E)}{100}\right]-6 \times H
$$

Sendo:

PCU $\left(\mathrm{kcal}^{\mathrm{kg}} \mathrm{kg}^{-1}\right)=$ Poder Calorífico Útil à umidade $\mathrm{E}$.

$\mathrm{E}(\%)=$ grau de umidade da madeira com base em peso úmido.

6 = fator de conversão referente à energia para evaporação da água de formação. 
Ripoli et al (1990), utilizando resultados de vários autores brasileiros, projetaram uma estimativa do potencial de energia disponível em um hectare de cana-de-açúcar, sem queima prévia, considerando-se uma produtividade agrícola de colmos de 70 t.ha ${ }^{-1}$ e industrial de $75 \mathrm{~L}^{-1} \mathrm{t}^{-1}$ de etanol (Tabela 5).

Tabela 5. Estimativa do potencial disponível em um hectare de cana-de-açúcar sem queima prévia

\begin{tabular}{lccc}
\hline Sub-produto & Produção.ha $^{-1}$ & Energia Mcal.ha $^{-1}$ & Relação energia/produção \\
\hline Etanol & 5.250 L.ha $^{-1}$ & 20.877 & 4,0 \\
Bagaço & 17, t.ha $^{-1}$ & 31.325 & 1,8 \\
Palhiço & 9.7 t.ha $^{-1}$ & 22.166 & 2,3 \\
\hline Total & - & 74.368 & - \\
\hline
\end{tabular}

Adaptado: Ripoli et al. (1990)

Ripoli (2001) estimou a origem da energia contida num hectare de cana-de-açúcar, a qual é apresentada na Figura 2.

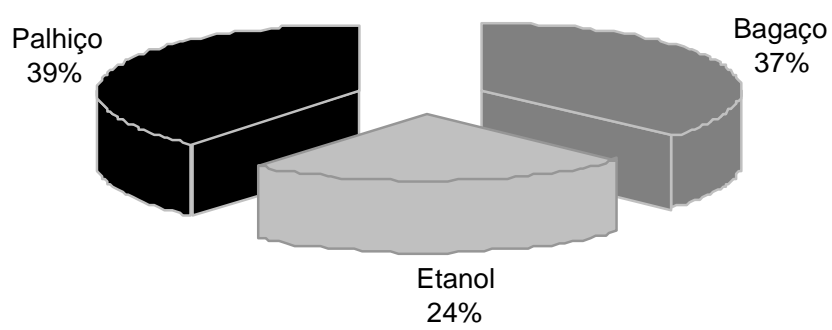

Figura 2 - Origem da energia contida em 1 ha de canavial (Ripoli, 2001)

Faccenda \& Souza (1998), ao realizarem um estudo sobre o desempenho em co-geração em uma usina de açúcar, observaram que o investimento, com a finalidade de aumentar a energia elétrica co-gerada, deve ter como conseqüência a melhora de todo o processo produtivo da indústria, 
gerando, com isto, receitas adicionais atribuídas à industrialização dos produtos tradicionais. Uma análise econômico-financeira de investimento em co-geração também deve ser considerada, sob pena de subestimar a existência da relação causa e efeito entre as variáveis analisadas.

\subsection{Recolhimento do palhiço}

As principais interrogações, segundo Ripoli (2001), quanto aos sistemas a serem adotados para retirar o palhiço do campo podem ser resumidas a: quantidade de material mineral no palhiço; distribuição do palhiço na área colhida e densidade muito variável desse material, dependendo do sistema de recolhimento e transporte a ser utilizado; custo de manipulação no campo e transporte; variabilidade do tamanho e umidade dos constituintes do material; armazenamento (deterioração, incêndio); gerenciamento do sistema; preparo, alimentação e combustão nas caldeiras; balanço energético e econômico do sistema a ser adotado. Diz, ainda, que as respostas a tais questionamentos somente serão obtidas por meio de estudos profundos, embasados em análises de "riscos e oportunidades" com suporte estatístico. Uma situação, altamente desejável, é a implementação de estudos, sob mesmas condições de campo, operacionais e gerenciais, com equipes multidisciplinares e sob o rigor, não apenas técnico, mas também científico.

Segundo Ripoli et al. (2003), estudos em desenvolvimento por usinas e órgãos de pesquisa oficiais e privados estão centrados nas seguintes opções de recolhimento do palhiço: a granel, por meio de colhedoras de forragens; enfardamento prismático ou cilíndrico; enfardamento por meio de prensas algodoeiras e colheita de cana integral, com as colhedoras operando com os sistemas de limpeza desligados.

Ripoli et al. (2003), ao avaliarem a eficiência energética (\%) do palhiço recolhido em três diferentes sistemas, obtiveram valores de 99,22\% para a colheita integral, $96,41 \%$ para o palhiço colhido a granel e $91,45 \%$ para o palhiço enfardado. 
Na Figura 3 é possível observar as etapas e opções dos diferentes sistemas de colheita e manipulação de palhiço, segundo Ripoli (2002).

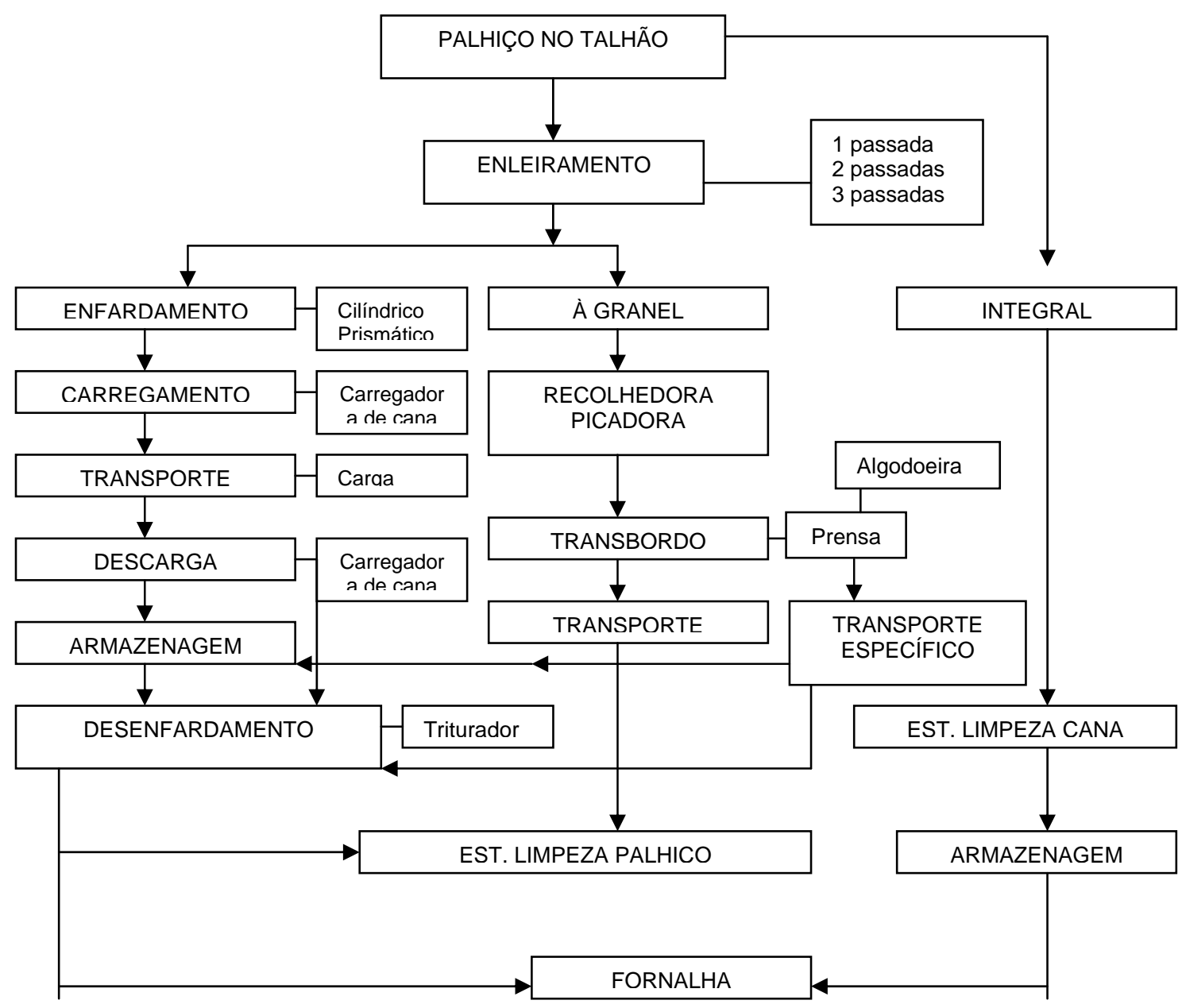

Figura 3 - Opções de sistemas de colheita e recolhimento de palhiço de canade-açúcar para geração de energia (Ripoli, 2002)

\subsubsection{Custos do recolhimento do palhiço}

Segundo Duarte et al. (1988), os custos das operações que envolvem o uso de máquinas dependem tanto das características das máquinas e implementos, como do ambiente de trabalho e da natureza das operações executadas, que também incluem o custo de oportunidade do fator de produção como forma de determinar os custos dos recursos empregados. 
Para Ripoli et al. (2003), o que se busca, em essência, atualmente com os estudos desenvolvidos para recolhimento do palhiço, são duas informações fundamentais: qual sistema apresenta o menor custo por tonelada e qual a percentagem de terra existente no palhiço posto na usina. Entretanto, estes autores entendem que está ocorrendo um viés neste posicionamento, pois, mais importante que o custo de palhiço posto na usina por determinado sistema de recolhimento é saber o custo da energia na forma de palhiço posto na usina, seja em equivalente barril de petróleo, seja por litro, de álcool, de gasolina ou ainda em kW. Afirmam, ainda, que é necessário saber também qual dos sistemas apresenta melhor eficiência energética. Esta preocupação é levantada, pois pode-se chegar a resultados de um determinado sistema de recolhimento onde o custo por tonelada seja o menor deles, porém o custo por energia, na forma de palhiço, não venha a ser o mais vantajoso.

\subsubsection{Terra contida no palhiço}

Alguns fatores de grande influência na percentagem de terra em cana-de-açúcar, segundo Braunbeck \& Bianchi (1988) são os procedimentos adotados para colheita e carregamento, tipo de máquina utilizado, e tipo de solo.

Segundo Sarriés (1997), a partir de observações efetuadas em experimentação de campo, considera-se que também poderiam influir na quantidade de terra, fatores como variedade da cana, maior exudação (diretamente dependente da intensidade do fogo durante a queima), número de cortes da cana, pressa no carregamento (dimensionamento incorreto das frotas), dentre outros.

Os principais fatores que afetam a quantidade de terra em cana-deaçúcar podem ser observados na Figura 4. 


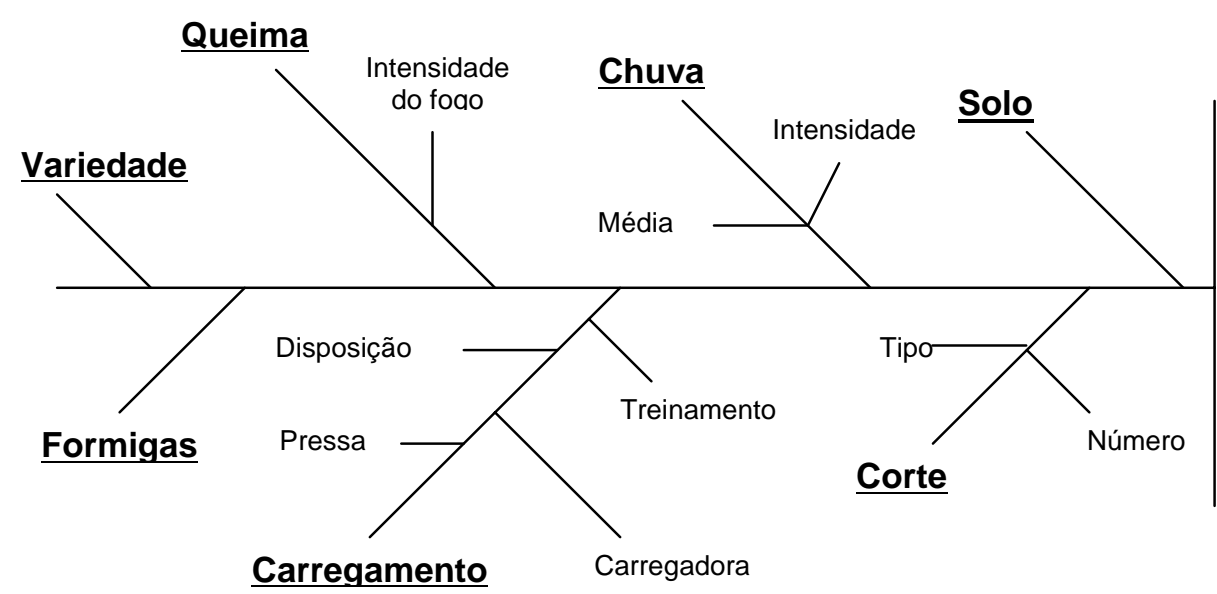

Terra

(\%)

Figura 4 - Diagrama de Ishikawa com os principais fatores que influenciam a quantidade de terra em cana-de-açúcar (Sarriés, 1997)

Também para Ripoli et al. (2003), a terra aderida ao material remanescente da colheita é devida, principalmente, à ação dos discos de corte basal e aos sistemas de ventilação das colhedoras, que levam ao acúmulo de partículas de solo, tornando-as um dos constituintes do palhiço já na sua condição "in natura" sobre o terreno. Posteriormente, dependendo do tipo de recolhimento que se venha a adotar, essa quantidade pode ser minimizada ou incrementada.

Ripoli et al. (2003), estudando os três sistemas de recolhimento do palhiço, encontraram percentagem de terra de $4,50 \%$ para o palhiço recolhido a granel, $1,39 \%$ para colheita integral e $0,63 \%$ para o palhiço enfardado.

\subsubsection{Enfardamento do palhiço}

A COPERSUCAR (1991) iniciou um estudo para avaliar a viabilidade de se recolher palhiço deixado no campo após a colheita da cana sem queima prévia, por meio de enfardadoras. Os resultados indicaram que o sistema de enfardamento prismático foi o mais indicado, devido a sua maior capacidade operacional, maior facilidade de operar com o palhiço e também devido a melhor ocupação do espaço da carroceria das unidades de transporte pelos fardos. Entretanto, este mesmo estudo demonstrou que os fardos prismáticos 
possuem baixa resistência às intempéries e devem ser removidos para área coberta, o mais breve possível. Por sua vez, alta densidade é uma qualidade desejável no fardo, uma vez que assim pode-se recolher e transportar mais material por unidade de tempo e volume, reduzindo-se os custos.

Molina Junior et al. (1991), estudando recolhimento de resíduos de colheita manual de cana sem queima, utilizando enfardadora de fardos cilíndricos, encontraram Capacidade Efetiva média de 0,61 ha. $\mathrm{h}^{-1}$, obtendo um custo total do sistema de recolhimento deste material de $\mathrm{R} \$ 44,93 \cdot \mathrm{t}^{-1}$.

Torrezan (2003) realizou um estudo visando avaliar alguns parâmetros de desempenho operacional nas operações de enleiramento e enfardamento prismático de palhiço de cana-de-açúcar colhida mecanicamente, sem queima prévia, e de suas eficiências energéticas. Concluiu que os fardos nos tratamentos de enleiramento triplo apresentaram a maior massa específica média $\left(211 \mathrm{~kg} \cdot \mathrm{m}^{-3}\right)$ e as maiores percentagens de terra $(6,41 \%)$, enquanto que nos tratamentos de enleiramento duplo a massa específica média foi $207 \mathrm{~kg} \cdot \mathrm{m}^{-3}$ e a percentagem de terra $6,31 \%$. As massas de terra aumentaram com enleiramento sucessivos.

COPERSUCAR (2001) realizou estudos para avaliar a viabilidade do recolhimento do palhiço de cana-de-açúcar utilizando enfardadoras, obtendo custos totais de $\mathrm{R} \$ 57,81 . \mathrm{t}^{-1}$ de palhiço. O custo do enfardamento foi responsável por $48,5 \%$ deste custo total.

\subsubsection{Recolhimento a granel de palhiço}

A baixa densidade do palhiço, resultando em grandes volumes na hora do transporte, e a dificuldade em desmanchar os fardos, são alguns dos problemas apontados no processo de utilização do palhiço pela indústria. Segundo Lima (2002), pode-se utilizar equipamentos comuns à colheita de algodão, como forrageira, bass boy, prensa, enleiradora e transmódulo. Este sistema, estudado na Companhia Energética Santa Elisa, resulta em fardões mais compactos (em média com 8 toneladas de peso), aumentando a 
densidade do material em até $60 \%$, viabilizando, segundo o autor, o recolhimento do palhiço a longa distância.

Lopez (1987) apresenta resultados de desempenhos operacional e econômico de sistemas de recolhimento do material remanescente da colheita de cana crua para posterior utilização energética, afirmando que a maior limitação se prende a sua baixa densidade, a qual, por sua vez, varia em função dos métodos de recolhimento e preparo para transporte. Dentre os métodos estudados, o que demonstrou viabilidade econômica foi aquele que utilizou enleiramento e picamento, no campo. Neste método as operações agrícolas envolvidas foram o enleiramento convencional e o recolhimento por meio de colhedora picadora de forragem, colocando o material sobre o transporte. $\mathrm{Na}$ Tabela 6, apresentam-se os resultados referentes aos custos de cada operação segundo Lopez (1987).

Tabela 6. Resultados obtidos por Lopez (1987) sobre operações agrícolas envolvidas na manipulação de palhiço

\begin{tabular}{lcc}
\hline \multicolumn{1}{c}{ Operações } & US\$. $\mathrm{t}^{-1}$ & $\mathrm{t} \cdot \mathrm{h}^{-1} \cdot$ efetiva \\
\hline Enleiramento & 1,24 & 7,0 \\
Recolhimento-picamento & 2,93 & 5,7 \\
Transporte & 2,35 & - \\
Carregamento (grua) & 0,51 & - \\
Total & 7,03 & \\
\hline
\end{tabular}

Teixeira \& Graminha ${ }^{1}$ (2001), citados por Ripoli (2002), trabalhando com colheita de palhiço à granel na Usina da Barra, obtiveram como dados preliminares, Capacidade Efetiva da colhedora de forragem de $160 \mathrm{t}_{\text {. dia }}{ }^{-1}$; custo do enleiramento e colheita de $\mathrm{R} \$ 18,65 \mathrm{t}^{-1}$; custo do transporte (distância média de $20 \mathrm{~km}$ ) de $R \$ 7,35 \mathrm{t}^{-1}$ e custo total do palhiço posto na usina de $R \$ 26,00 \mathrm{t}^{-1}$.

\footnotetext{
${ }^{1}$ TEIXEIRA, J.P.; GRAMINHA, C. Usina da Barra.
} 
Ripoli et al. (1990), afirmam que para o aproveitamento do palhiço como fonte energética, algumas dificuldades deverão ser enfrentadas, tais como: sua baixa densidade in natura $\left(25 \mathrm{~kg} \cdot \mathrm{m}^{-3}\right)$; o seu teor médio de terra $(7 \%)$ e seu relativo e elevado grau de umidade (ponteiros $=76,9 \%$; folhas verdes $=65,7 \%$ e palhas $=7,6 \%)$. 


\section{DESEMPENHO OPERACIONAL DE DOIS DIFERENTES ENLEIRADORES OPERANDO SOBRE PALHIÇO DE CANA-DE-AÇÚCAR}

\subsection{Introdução}

A colheita de cana-de-açúcar sem queima prévia tem sido adotada devido às pressões ambientais e legais que vem ocorrendo sobre o setor canavieiro, e às mudanças políticas que resultaram na desregulamentação do setor, exigindo dos empresários envolvidos neste agronegócio uma visão mais ampla das possibilidades de agregação de valor que esta cultura oferece.

O palhiço, antes visto apenas como um entrave na produção de canade-açúcar, devido a grande quantidade produzida e deixada sobre o solo, passasse a receber maior atenção, haja vista que suas características o tornam uma excelente fonte de biomassa para a produção de energia. Dentro deste cenário, as possibilidades de retirada e aproveitamento deste material como fonte de energia passaram a ser alvo de estudos buscando viabilizar sua utilização de maneira racional e econômica.

O enleiramento do palhiço de cana-de-açúcar tem sido adotado pelas usinas que colhem sem queima prévia, numa tentativa de minimizar os problemas ocasionados pela grande quantidade desse material sobre o solo.

Assim, para analisar o aproveitamento do palhiço por meio de seu recolhimento à granel, torna-se necessário estudar o desempenho dos ancinhos enleiradores utilizados nesse processo. A hipótese de trabalho é que não existem diferenças significativas entre os dois tipos de enleiradores estudados, operando sobre palhiço de cana-de-açúcar. 


\subsection{Material e métodos}

\subsubsection{Material}

Os estudos e determinações de campo contidos neste estudo foram realizados no final da safra de 2001, em área pertencente ao grupo COSAN, localizada no município de Piracicaba, Estado de São Paulo. As coordenadas geográficas do centro da área de estudo são: Latitude 2240'30" Sul, Longitude 47³6'38" Oeste e Altitude de 605 metros. O talhão possui área de 9,63ha com $6 \%$ de declividade e face de exposição Noroeste, com solo caracterizado como Latossolo Roxo. A variedade plantada foi a RB85 5113, em $2^{\circ}$ corte, no espaçamento de $1,40 \mathrm{~m}$, e com produtividade média de colmos de 108 t.ha $^{-1}$.

\section{- Instrumentos para mensurações dimensionais e volumétricos}

Para determinações de tempo de percurso dos conjuntos mecanizados durante a operação de enleiramento, foram utilizados dois cronômetros digitais das marcas $\mathrm{CASIO}^{{ }^{\circledR *}}$ e SPALDING ${ }^{\circledR}$ com capacidade de leitura de $0,1 \mathrm{~s}$.

O consumo de combustível foi determinado com auxílio de buretas graduadas, com capacidade volumétrica máxima de $1.000 \mathrm{~mL}$ e capacidade de leitura de $10 \mathrm{~mL}$.

\section{- Equipamentos objetos de estudo}

\section{A) Conjunto 1: enleirador + trator}

- Características do enleirador:

Marca e modelo: DMB, com 4 discos verticais (Apêndice 1A).

- Características do trator:

Marca e modelo: Ford 6610

Potência nominal: 65,4kW com rotação nominal de 2200rpm.

\footnotetext{
* A citação de marcas neste trabalho não significa preferência do autor.
} 


\section{B) Conjunto 2: enleirador + trator}

- Características enleirador:

Marca e modelo: John Deere, Modelo 64 (Apêndice 1B)

- Características do trator:

Marca e modelo: MF 299

Potência nominal: 95,6kw, com rotação nominal de 2200rpm.

\subsubsection{Métodos}

Foram considerados dois tratamentos, T1 e T2, cada um representando um tipo de ancinho enleirador. O tratamento T1 referiu-se ao trator Ford 6610 com o enleirador DMB e o tratamento T2 pelo trator MF 299 com enleirador John Deere, modelo 64.

\section{- Umidade e granulometria do solo}

Foram tomadas cinco amostras casualizadas de solo, na área de cada tratamento, na profundidade 0 a $5 \mathrm{~cm}$, perfazendo um total de 10 amostras, com a finalidade de obter-se um referencial sobre a maior ou menor probabilidade de arraste de matéria estranha mineral dentro do material recolhido pela máquina por ocasião da maior ou menor umidade do solo. As amostras foram acondicionadas em recipientes metálicos hermeticamente fechados e após codificadas, foram levadas ao Laboratório de Máquinas Agrícolas do Departamento de Engenharia Rural da ESALQ/USP, onde foram pesadas e secas em estufa, durante 48 horas, a temperatura de $105^{\circ} \mathrm{C}$, para obtenção da umidade.

A seguir, essas amostras foram encaminhadas ao Laboratório de Hidráulica do Departamento de Engenharia Rural da ESALQ/USP, onde foram realizadas as determinações de granulometria, aplicando-se o método Steel \& Bradfield (1934), que visa a obtenção da fração argila. A fração areia foi obtida a 
partir do peneiramento úmido (peneira 270, diâmetro de 0,053mm), seguido de fracionamento por peneiramento a seco.

\section{- Repetições ou ciclos operacionais}

Nos ensaios utilizou-se de dois conjuntos de trator mais enleiradores, realizando a operação de "enleiramento duplo", ou seja, a formação de uma leira composta pelo material enleirado por duas passadas da máquina, ida e volta. Assim, cada repetição ou ciclo operacional considerou o percurso (p1) + manobra $(\mathrm{m} 1)+$ percurso $(\mathrm{p} 2)+$ manobra $(\mathrm{m} 2)$, como pode ser observado na Figura 5.

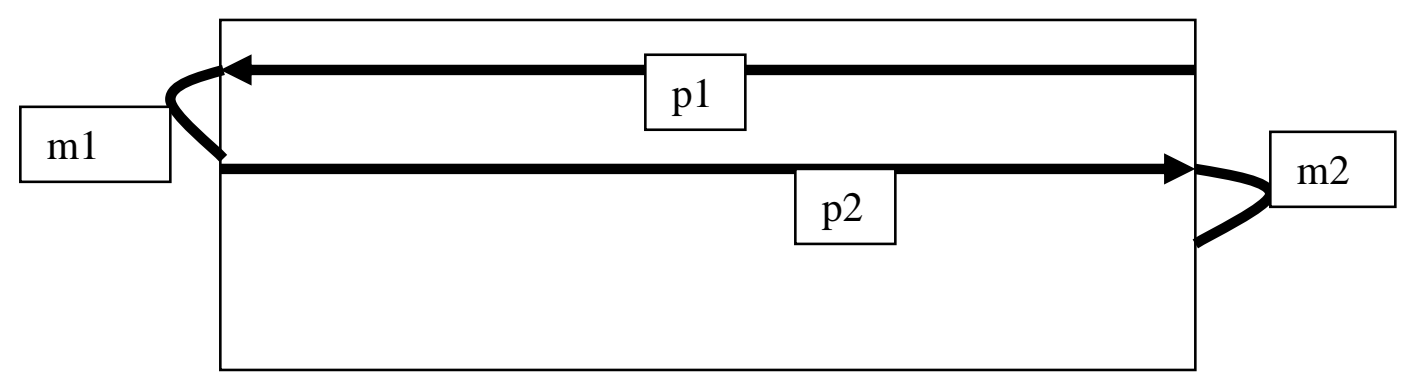

Figura 5 - Esquema representando o ciclo operacional (repetição) da operação de enleiramento. p1=percurso; m1=manobra; p2=percurso e $\mathrm{m} 2=$ manobra

As leiras duplas formadas ao final de cada ciclo operacional tiveram comprimento médio de $749 \mathrm{~m}$ no tratamento T1 e $755 \mathrm{~m}$ no tratamento T2, sendo que a distância média entre o centro das leiras foi de $5,40 \mathrm{~m}$ para o tratamento T1 e 7,14m para o tratamento $\mathrm{T} 2$.

\section{- Tempos}

Durante a realização dos ciclos operacionais cronometrou-se os tempos de cada ciclo operacional, anotando-se, em planilha especificamente elaborada para isso, os valores referentes aos tempos de percursos (efetivo), tempos de manobras, tempos de eventuais paradas (embuchamentos, e demais situações eventuais) e tempos operacionais (efetivos + manobras + demais paradas). 


\section{- Amostragem do palhiço}

Para determinação da umidade do palhiço enleirado, foram recolhidas cinco amostras deste material em cada repetição. O palhiço foi recolhido, armazenado em sacos plásticos posteriormente vedados e codificados, e essas amostras foram levados ao laboratório de máquinas agrícolas, onde foram pesadas e secas em estufa durante 48 horas a temperatura de $65^{\circ} \mathrm{C}$.

Com base na diferença do peso úmido e do peso seco foi calculada a umidade presente no material, utilizando-se a equação 3 .

$$
\operatorname{UPEnl}(\%)=\left\{\left[\frac{(M U-M S)}{M U}\right] \times 100\right\}
$$

Sendo:

MU = Massa úmida;

MS = Massa seca;

UPEnl (\%) = Umidade do palhiço.

\section{- Consumo de combustível}

Para a análise dos consumos de combustível, tanto operacional quanto efetivo, utilizou-se a metodologia proposta por Ripoli (1991).

Os tratores utilizados na operação de enleiramento tiveram seus tanques de combustível completados antes do início da operação. Para determinação do consumo de combustível, utilizou-se uma bureta graduada para completar o tanque após cada ciclo operacional. A quantidade de diesel necessária para completar novamente o tanque após cada ciclo correspondeu ao consumo de combustível na operação, sendo anotada em planilha específica . 


\section{- Variáveis consideradas}

\section{- Velocidade de enleiramento $\left(\mathrm{km} \cdot \mathrm{h}^{-1}\right)$}

Obtida através da relação entre o percurso efetivo realizado pelo conjunto mecanizado durante a operação de enleiramento e o tempo efetivo necessário para conclusão do percurso, conforme a equação 4.

$$
V M E n l=\left(\frac{P E}{T E}\right) \times 3,6
$$

Sendo:

VMEnl = Velocidade de enleiramento $\left(\mathrm{km} \cdot \mathrm{h}^{-1}\right)$;

$\mathrm{PE}=$ Percurso efetivo da operação de enleiramento $(\mathrm{m})$;

TE = Tempo efetivo da operação de enleiramento (s).

\section{- Capacidades efetiva e operacional de enleiramento (ha. $\mathrm{h}^{-1}$ )}

As capacidades de campo efetiva e operacional foram obtidas pela razão entre a área enleirada e o tempo necessário para a operação de enleiramento (equações 3 e 4). A área enleirada em cada repetição foi calculada com o auxílio da equação 5.

$$
\text { CAPEEnl }=\left[\frac{A E}{(T E \times 3600)}\right]
$$

Sendo:

CAPEEnl = Capacidade efetiva de enleiramento $\left(\right.$ ha.$\left.h^{-1}\right)$;

$\mathrm{AE}=$ Área enleirada por repetição (ha.repetição ${ }^{-1}$ );

TE = Tempo efetivo da operação de enleiramento (s).

$$
\text { CAPOEnl }=\left[\frac{A E}{(T O \times 3600)}\right]
$$

Sendo:

CAPOEnl = Capacidade operacional de enleiramento $\left(\right.$ ha. $\mathrm{h}^{-1}$ );

$\mathrm{AE}=$ Área enleirada por repetição (ha.repetição ${ }^{-1}$ );

$\mathrm{TO}=$ Tempo operacional da operação de enleiramento (s). 
$A E=D E \times\left(\frac{P E}{10000}\right)$

Sendo:

$\mathrm{AE}=$ área enleirada por repetição $\left(\mathrm{m}^{2}\right)$;

DE = Distância entre eitos (m);

$\mathrm{PE}=$ Percurso efetivo da operação de enleiramento $(\mathrm{m})$;

\section{- Consumos efetivo e operacional de combustível (L. $\left.\mathrm{t}^{-1}\right)$}

Os consumos efetivo e operacional de combustível na operação de enleiramento foram obtidos através da razão entre o consumo em litros por hectare e a quantidade de palhiço enleirado por hectare. Para tanto, foram utilizadas as equações 8 e 9 .

CONEEnl $=\left(\frac{C E}{\text { Palhiço }}\right)$

Sendo:

CONEEnl = Consumo efetivo $\left(\right.$ L. $\left.\mathrm{t}^{-1}\right)$;

$\mathrm{CE}=$ Consumo efetivo $\left(\right.$ L.ha $\left.^{-1}\right)$;

Palhiço $=$ Quantidade de palhiço úmido enleirado $\left(\right.$ t.ha $\left.^{-1}\right)$.

CONOEnl $=\left(\frac{C O}{\text { Palhiço }}\right)$

Sendo:

CONOEnl $=$ Consumo operacional $\left(L . t^{-1}\right)$;

$\mathrm{CO}=$ Consumo operacional $\left(\right.$ L.ha $\left.^{-1}\right)$;

Palhiço = Quantidade de palhiço úmido enleirado (t.ha $\left.{ }^{-1}\right)$.

\section{- Eficiência de campo (\%)}

A eficiência ou rendimento de campo da operação de enleiramento do palhiço foi obtida pela razão entre suas capacidades de campo operacional e efetiva, conforme apresentado na equação 10. 


$$
\text { EFEnl }=\left(\frac{\text { CAPOEnl }}{\text { CAPEEnl }}\right)
$$

Sendo:

EFEnl = Eficiência de campo (\%);

CAPOEnl $=$ Capacidade operacional de enleiramento $\left(\right.$ ha. $\left.\mathrm{h}^{-1}\right)$;

CAPEEnl = Capacidade efetiva de enleiramento $\left(\right.$ ha $\left.\cdot h^{-1}\right)$.

\section{- Custo da operação de enleiramento $\left(R \mathbf{R} . \mathrm{EBP}^{-1}\right)^{1}$}

Para o cálculo do custo da operação de enleiramento de ambos os tratamentos em $\mathrm{R} \$ . E B P^{-1}$ para o palhiço enleirado foram consideradas as informações fornecidas pela Usina Costa Pinto - Grupo COSAN e o poder calorífico útil calculado para cada tratamento (Equação 11).

$$
C E n l=\left(\frac{\text { Custo }}{P C U}\right)
$$

Sendo:

CEnl = Custo da operação de enleiramento $\left(R \$ . E B P^{-1}\right)$;

Custo = Custo da operação de enleiramento $\left(R \$ . t^{-1}\right)$;

$\mathrm{PCU}=$ Poder calorífico útil do palhiço enleirado (EBP.t $\left.{ }^{-1}\right)$.

\section{- Análise estatística}

O delineamento experimental utilizado foi o inteiramente casualizado sendo que a unidade experimental ou parcela empregada foi a leira dupla de palhiço de cana-de-açúcar, representando uma repetição ou ciclo operacional.

Para a análise estatística dos dados obtidos na operação de enleiramento, foram realizados dois tratamentos, com 8 repetições cada, utilizando-se das informações fornecidas pela estatística descritiva dos dados e pela comparação da diferença entre as médias para as variáveis através do Teste F ANOVA com $5 \%$ de significância. Para tanto, foram utilizados os programas MICROSOF EXCEL ${ }^{\circledR}$ e SAS $^{\circledR}$.

\footnotetext{
${ }^{1}$ EBP - Equivalente barril de petróleo
} 


\subsection{Resultados e discussão}

\subsubsection{Caracterização das condições do solo}

As Tabelas 7 e 8 apresentam os resultados da granulometria e umidade do solo, respectivamente.

Tabela 7. Umidade do solo antes da operação de enleiramento

\begin{tabular}{lcccccc}
\hline Médias & $\begin{array}{c}\text { P.B.U. } \\
(\mathrm{g})\end{array}$ & $\begin{array}{c}\text { Tara Lata } \\
(\mathrm{g})\end{array}$ & $\begin{array}{c}\text { P.L.U. } \\
(\mathrm{g})\end{array}$ & $\begin{array}{c}\text { P.B.S. } \\
(\mathrm{g})\end{array}$ & $\begin{array}{c}\text { P.L.S. } \\
(\mathrm{g})\end{array}$ & $\begin{array}{c}\mathrm{U} \\
(\%)\end{array}$ \\
\hline T1 & 177,47 & 36,45 & 141,02 & 154,90 & 118,45 & 15,86 \\
T2 & 204,69 & 39,21 & 165,48 & 175,08 & 135,87 & 17,98 \\
\hline P.B.U.= peso bruto úmido; P.L.U.= peso líquido úmido; & P.B.S.= peso bruto \\
seco; P.L.S.= peso líquido seco; U= umidade \\
Tabela 8. Granulometria do solo \\
\hline \multicolumn{5}{c}{ Argila } \\
\hline \multicolumn{5}{c}{ Solo } \\
Latossolo Roxo & 28,34 & Silte & Areia \\
\hline
\end{tabular}

A Tabela 9 apresenta a análise da variância dos dados referentes à umidade do solo, demonstrando que o $\mathrm{F}$ calculado para estes dados, pelo Teste de $\mathrm{F}$ ANOVA foi de 11,64, sendo maior que o $\mathrm{F}$ tabelado, cujo valor foi 5,32. Assim, pode-se dizer que houve diferença estatística significativa entre as médias.

Tabela 9. Análise da variância para umidade do solo

Tratamentos

\begin{tabular}{ccccccc} 
Variável & F calc. & F tab. & T1 & cV & T2 & CV \\
\hline Umidade do solo & 11,378 & 5,317 & $15,86^{\mathrm{b}}$ & 6,04 & $17,98^{\mathrm{a}}$ & 4,54
\end{tabular}

\footnotetext{
$\overline{a, b}$ Médias seguidas de letras diferentes apresentam diferenças significativas. $F$ calc. $=\mathrm{F}$ calculado; $\mathrm{F}$ tab. $=\mathrm{F}$ tabelado; $\mathrm{T} 1=$ tratamento $1 ; \mathrm{T} 2=$ tratamento $2 ; \mathrm{cV}=$ coeficiente de variação
} 


\subsubsection{Enleiramento}

Na Tabela 10, encontram-se, resumidos, os valores obtidos pela análise estatística, para as variáveis consideradas nesta operação.

Tabela 10. Resumo estatístico da operação de enleiramento

\begin{tabular}{|c|c|c|c|c|}
\hline Variáveis & T1 & $\mathrm{CV}$ & T2 & cV \\
\hline UP (\%) & 32,79 & 20,86 & 42,09 & 16,41 \\
\hline VMEnl $\left(\mathrm{km} \cdot \mathrm{h}^{-1}\right)$ & $9,88^{\mathrm{a}}$ & 1,79 & $8,19^{b}$ & 5,27 \\
\hline CAPEEnl $\left(\right.$ ha. $^{-1}$ ) & $5,34^{b}$ & 1,88 & $5,84^{\mathrm{a}}$ & 5,47 \\
\hline CAPOEnl $\left(\right.$ ha. $\left.h^{-1}\right)$ & $4,70^{b}$ & 1,82 & $5,06^{a}$ & 4,53 \\
\hline CONEEnl $\left(\right.$ L.t $\left.\mathrm{t}^{-1}\right)$ & $0,030^{b}$ & 6,23 & $0,043^{a}$ & 7,70 \\
\hline CONOEnl (L.t $\left.{ }^{-1}\right)$ & $0,034^{b}$ & 11,70 & $0,050^{a}$ & 13,49 \\
\hline EFEnl (\%) & $88,06^{\mathrm{a}}$ & 1,86 & $86,62^{\mathrm{a}}$ & 1,78 \\
\hline PCUEnl (Mcal. $\left.\mathrm{t}^{-1}\right)$ & $2709,38^{a}$ & 10,31 & $2328,80^{b}$ & 12,12 \\
\hline PCUEnl (EBP. $\left.\mathrm{t}^{-1}\right)$ & $2,45^{\mathrm{a}}$ & 10,31 & $2,10^{b}$ & 12,12 \\
\hline CEnl (R\$.EBP $\left.{ }^{-1}\right)$ & $0,49^{\mathrm{a}}$ & 10,27 & $0,24^{b}$ & 12,46 \\
\hline
\end{tabular}

a,b Médias seguidas de letras diferentes apresentam diferenças estatísticas significativas. VMEnl= velocidade média; CAPEEnl= Capacidade Efetiva; CAPOEnl= Capacidade Operacional; CONEEnl= Consumo Efetivo; CONOEnl= Consumo Operacional; EFEnl= Eficiência de Campo; PCUEnl= poder calorífico útil; CEnl= custo; T1 e T2= tratamentos; $c v=$ coeficiente de variação

\section{- Velocidade de enleiramento}

A variável velocidade média de trabalho dos conjuntos mecanizados apresentou maior valor para o tratamento $T 1$, com $9,88 \mathrm{~km} \cdot \mathrm{h}^{-1}$, enquanto que para o tratamento T2, a média foi de $8,19 \mathrm{~km} \cdot \mathrm{h}^{-1}$, diferindo estatisticamente entre si. 


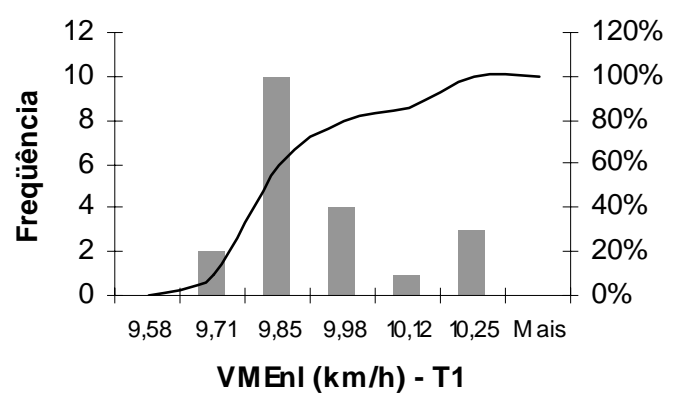

Freqüência $\%$ cumulativo

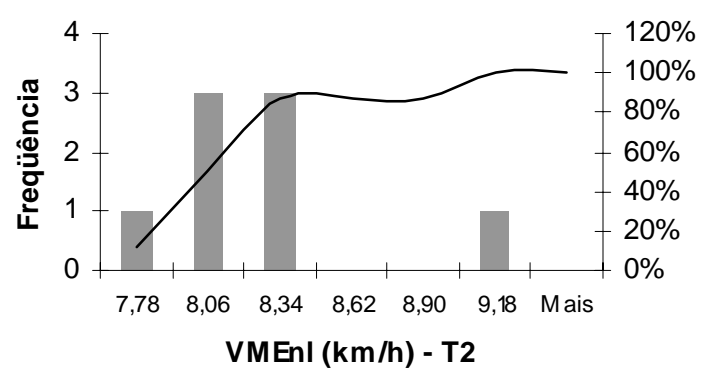

Freqüência — \% cumulativo (B)

Figura 6 - Histograma da velocidade média de enleiramento. (A) Tratamento T1. (B) Tratamento T2

É possível observar nos histogramas apresentados na Figura 6, que a amplitude de velocidade para o tratamento T1 foi menor $\left(0,67 \mathrm{~km} \cdot \mathrm{h}^{-1}\right)$ do que para o tratamento T2 $\left(1,40 \mathrm{~km} \cdot \mathrm{h}^{-1}\right)$, ou seja, para o tratamento T1 houve menor variação na velocidade de trabalho. Para o tratamento $\mathrm{T} 1$, a faixa de velocidade de maior ocorrência foi de $9,85 \mathrm{~km} \cdot \mathrm{h}^{-1}(50 \%)$, enquanto que para o T2, maior número de ocorrências foi nas faixas 8,06 e $8,34 \mathrm{~km} \cdot \mathrm{h}^{-1}$ totalizando $75 \%$. Essas variações na velocidade entre os enleiradores podem ser justificadas pelas diferenças estruturais das máquinas, uma vez que o enleirador do tratamento T1 tem constituição e princípio de funcionamento mais simples que o modelo utilizado no tratamento T2. Outro fator que deve ser considerado, é que cada conjunto mecanizado foi operado por um tratorista. Além disso, a desuniformidade de distribuição do palhiço sobre o solo, verificada através da constatação visual, também pode ter provocado a diferença entre as velocidades dos conjuntos.

\section{- Capacidade Operacional, Capacidade Efetiva e Eficiência de Campo}

Quanto à Capacidade Operacional e Efetiva dos conjuntos, o tratamento T2 apresentou médias de 5,06 e 5,84ha. $\mathrm{h}^{-1}$, respectivamente, enquanto que para o tratamento $T 1$, as médias foram de 4,70 e $5,34 h a \cdot h^{-1}$. $O$ 
Teste F para análise da variância comprovou que houve diferença estatística ao nível de $5 \%$ de probabilidade entre os mesmos, para ambas as variáveis.

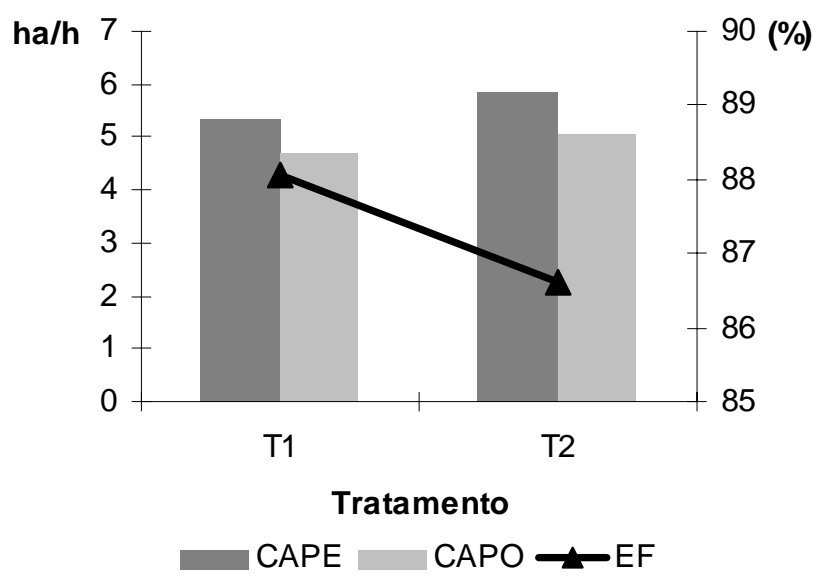

Figura 7 - Capacidade Efetiva, Operacional e Eficiência de Campo

Na Figura 7, pode-se observar as médias das Capacidades Efetiva e Operacional do enleiramento, bem como a Eficiência de Campo para esta operação. Nota-se que o tratamento T1 apresenta menor Capacidade Operacional e efetiva. Pelo Teste $\mathrm{F}$ de análise da variância, verificou-se que para a Eficiência de Campo não houve diferença estatística significativa a 5\% de probabilidade.

As Capacidades Operacional e efetiva foram maiores para o tratamento T2 devido a maior velocidade do conjunto mecanizado e maior largura efetiva de trabalho do enleirador. Já a Eficiência de Campo do tratamento T2 foi menor que no tratamento $\mathrm{T} 1$, devido à necessidade deste conjunto de maior tempo para realização das manobras na cabeceira do talhão. Assim, o conjunto T1 apresentou média de 37,85s para manobras de cabeceira, enquanto que o tratamento T2 apresentou média de 51,25s. 


\section{- Consumo Operacional e Efetivo}

Ao se analisar o Consumo Efetivo de combustível dos conjuntos mecanizados utilizados na operação de enleiramento, observa-se, na Figura 8 , que o tratamento T2 teve um consumo médio de $0,043 \mathrm{~L} \cdot \mathrm{t}^{-1}$, enquanto que o tratamento T1 apresentou um consumo médio de 0,030L.t. $\mathrm{t}^{-1}$.
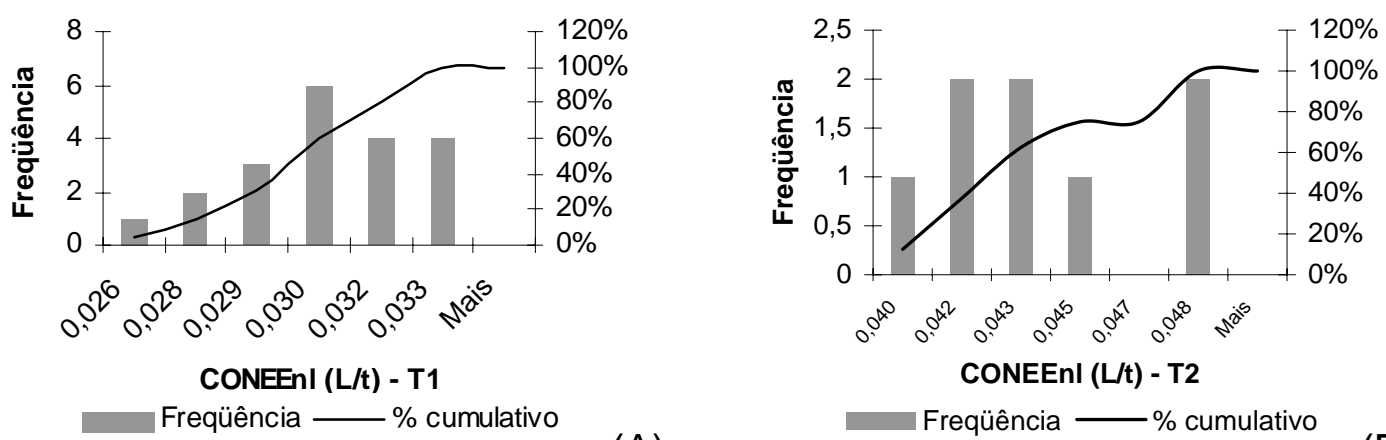

(A)

(B)

Figura 8 - Histograma do Consumo Efetivo de combustível no enleiramento. (A) Tratamento 1. (B) Tratamento 2. CONEEnl= Consumo Efetivo

É possível observar que o tratamento T1 possui uma distribuição mais uniforme dos dados relativos a esta variável, que apresenta assimetria negativa, ou seja, a média dos dados (0,030L.t $\left.\mathrm{t}^{-1}\right)$ está localizada à direita do centro da figura (mediana) e a cauda a esquerda é alongada. O histograma para o consumo de combustível do tratamento T2, quanto à simetria, pode ser classificado como de assimetria positiva, sendo um histograma de dois picos, onde estão concentradas $75 \%$ das ocorrências. Pela classificação de Spiegel (1974), a curva de freqüência do tratamento T1 é do tipo de assimetria negativa, desviada para a esquerda, enquanto que o tratamento T2 apresenta curva de freqüência do tipo bimodal.

$\mathrm{Na}$ Figura 9, são apresentados os histogramas de Consumo Operacional de combustível no enleiramento, para os dois tratamentos. 

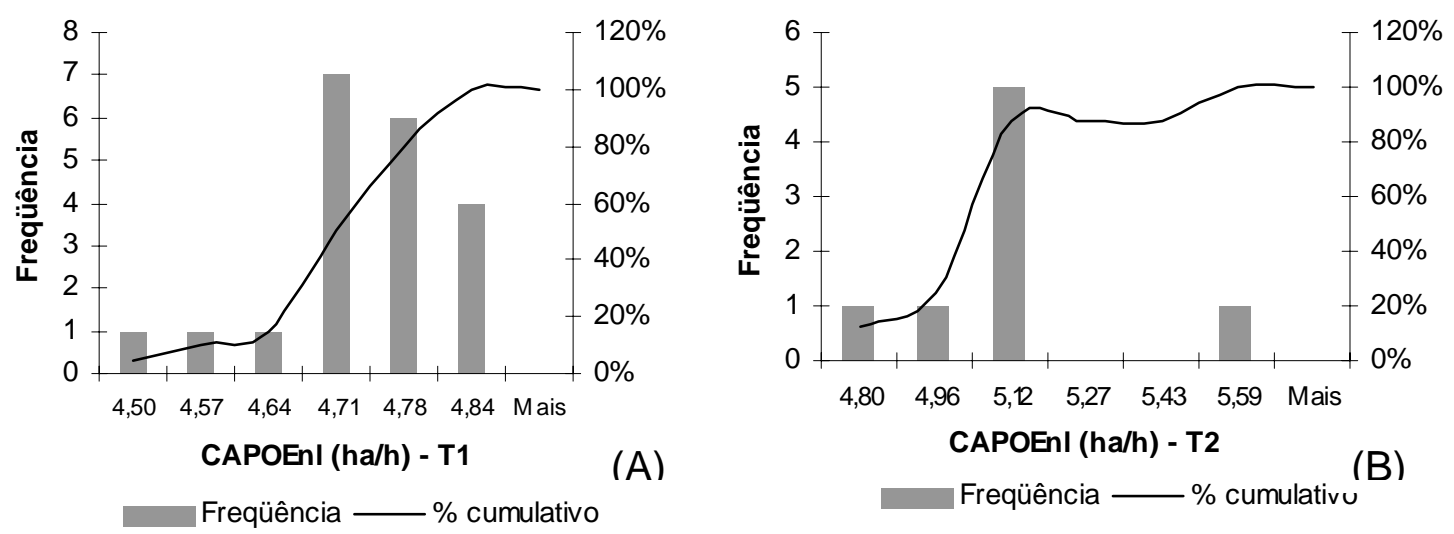

Figura 9 - Histograma do Consumo Operacional de combustível no enleiramento. (A) Tratamento 1. (B) Tratamento 2. CONOEnl= Consumo Operacional

Como é possível observar, as curvas de distribuição de freqüência para esta variável, são semelhantes aquelas apresentadas na Figura 8, retratando o Consumo Efetivo.

\section{- Umidade e poder calorífico útil do palhiço enleirado}

A umidade do palhiço enleirado apresentou diferenças estatísticas significativas no Teste $F$ para análise da variância ao nível de $5 \%$ de probabilidade, sendo que o tratamento T1 apresentou média de $32,79 \%$ e o tratamento T2 teve média de 42,09\%, como apresentado na Tabela 10 . O coeficiente de variação do tratamento $\mathrm{T} 1$, de $20,86 \%$ foi maior do que o do tratamento T2, com $16,41 \%$, demonstrando ter havido maior variação para os dados do primeiro. Isto fica mais claro ao adotar-se os critérios de Gomes (1990) para análise do coeficiente de variação (cv) para ensaios agrícolas. Segundo este critério, os tratamentos T1 e T2 apresentaram cv considerado médio. Essa diferença na umidade apresentada em cada repetição pode ser justificada pelo horário de realização das mesmas, tendo em vista que a coleta das amostras para umidade do palhiço enleirado foi realizada durante o transcorrer do experimento, e nas primeiras horas da manhã, o palhiço naturalmente encontra-se com maior umidade. 
Como neste estudo não foram realizadas análises laboratoriais sobre o poder calorífico do palhiço, optou-se por utilizar as informações encontradas na bibliografia, utilizado-se os dados obtidos por Ripoli (1991), apresentados na Tabela 11.

Tabela 11. Poder calorífico superior (PCS) segundo Ripoli (1991)

\begin{tabular}{|c|c|c|c|c|}
\hline \multirow{2}{*}{ Autor } & \multicolumn{4}{|c|}{ PCS (Mcal. $\left.\mathrm{t}^{-1}\right)$} \\
\hline & Ponteiros & Folhas verdes & Palhas & Palhiço \\
\hline $\begin{array}{l}\text { Ripoli (1991) } \\
\text { (1) }\end{array}$ & 4350,9 & 4412,1 & 4419,8 & $4426,8^{*}$ \\
\hline
\end{tabular}

Assim, na Tabela 12, é possível observar que as médias dos dois tratamentos apresentaram valores bastante distintos, com PCU igual a 2,45EBP. $\mathrm{t}^{-1}$ para o tratamento $\mathrm{T} 1$ e 2,10EBP. $\mathrm{t}^{-1}$ para o tratamento $\mathrm{T} 2$. A análise estatística dessas médias comprovou que estas diferem entre si, ao nível de 5\% de probabilidade. Esta diferença de PCU para os dois tratamentos se deve basicamente a diferença de umidade do material enleirado, e uma vez que o tratamento T1 apresentou menor umidade no palhiço $(32,79 \%)$ do que o tratamento T2 (42,10\%), esse maior poder calorífico é justificado.

Tabela 12. Poder calorífico útil (PCU) em Mcal. $\mathrm{t}^{-1}$ e EBP. $\mathrm{t}^{-1}$ para o palhiço enleirado, considerando-se a umidade do material

\begin{tabular}{lccc}
\hline \multicolumn{1}{c}{ Tratamento } & Umidade (\%) & PCU (Mcal. $\left.\mathrm{t}^{-1}\right)$ & PCU (EBP. ${ }^{-1}$ ) \\
\hline T1 & 32,79 & 2709,38 & 2,45 \\
T2 & 42,09 & 2328,80 & 2,10 \\
\hline
\end{tabular}

\section{- Custo do enleiramento}

$\mathrm{Na}$ Tabela 13 estão apresentados os valores fornecidos pelo Grupo COSAN referentes ao custo da operação de enleiramento em $\mathrm{R} \$ \mathrm{t}^{-1}$. 
Tabela 13. Custo em $\mathrm{R} \$ \cdot \mathrm{t}^{-1}$ do enleiramento, a partir do custo horário e por unidade de área fornecido pelo Grupo COSAN

\begin{tabular}{ccc}
\hline Tratamentos & T1 & T2 \\
\hline Custos $\left(\mathrm{R} \$ . \mathrm{t}^{-1}\right)$ & 1,20 & 0,49 \\
\hline
\end{tabular}

Após a conversão dos valores de $\mathrm{R} \$ . \mathrm{t}^{-1}$ para $\mathrm{R} \$ . E B P^{-1}$, o Teste $\mathrm{F}$ para análise da variância, comprovou haver diferença estatística significativa entre as médias dos tratamentos. Os coeficientes de variação para os tratamentos foram de 10,27 e 12,46\% para os tratamentos T1 e T2, respectivamente, demonstrando que a variação nos dados foi considerada média.

$\mathrm{Na}$ Tabela 14, estão apresentados os custos para operação de enleiramento em R\$.EBP ${ }^{-1}$. 
Tabela 14. Custo em R $\$ . E \mathrm{BP}^{-1}$ do enleiramento

\begin{tabular}{lcc}
\hline Tratamentos & $\mathrm{T} 1$ & $\mathrm{~T} 2$ \\
\hline Custos $\left(\mathrm{R} \$ . \mathrm{EBP}^{-1}\right)$ & 0,49 & 0,24 \\
\hline & & \\
Observa-se que o custo do tratamento $\mathrm{T} 1$ em reais por EBP foi \\
praticamente duas vezes maior do que o custo apresentado pelo tratamento T2. \\
Quando se utiliza a comparação entre $\mathrm{R}^{-1} \mathrm{t}^{-1}$ e $\mathrm{R} \$ . \mathrm{EBP}^{-1}$ encontra-se uma \\
diferença menor entre os custos dos tratamentos para a segunda observação. \\
Isto se deve a diluição dos custos quando se adota a energia como padrão de \\
comparação. Neste caso, o tratamento $\mathrm{T} 1$, por apresentar menor umidade \\
possuiu maior poder calorífico útil, e conseqüentemente o custo foi diluído ao \\
ser transformado em equivalente barril de petróleo (EBP).
\end{tabular}




\subsection{Conclusões}

- A hipótese inicial de trabalho foi comprovada, ou seja, não existe diferença significativa em termos do efeito dos enleiradores nas variáveis consideradas neste estudo. 


\section{COLHEDORA AUTOPROPELIDA DE FORRAGEM OPERANDO SOBRE PALHIÇO DE CANA-DE-AÇÚCAR SEM QUEIMA PRÉVIA: RESULTADOS DE ALGUNS PARÂMETROS DE DESEMPENHO OPERACIONAL}

\subsection{Introdução}

Várias têm sido as discussões tentando-se solucionar o problema do palhiço remanescente da colheita de cana-de-açúcar sem queima prévia, envolvendo diferentes formas de retirada deste material do campo com o intuito de utilizá-lo na co-geração de energia. Estes estudos abrangem desde o enfardamento do palhiço até a colheita integral da cana-de-açúcar.

O recolhimento à granel desse material vem sendo considerado como uma possibilidade de aproveitamento desta fonte de biomassa, disponibilizandoa para as usinas de maneira prática e economicamente viável. Entretanto, alguns fatores devem ser considerados quando do estudo do recolhimento à granel, tais como a baixa densidade do palhiço, a influência do ancinho enleirador sobre 0 desempenho operacional da recolhedora, e a quantidade de terra agregada ao material recolhido levada até as caldeiras das usinas/destilarias (Ripoli, 2001).

O presente estudo determinou alguns parâmetros de desempenho operacional de uma colhedora auto-propelida de forragem operando sobre leiras de palhiço formadas por dois diferentes tipos de enleiradores. A hipótese de trabalho é a de que o tipo de enleirador utilizado não interfere nos resultados de desempenho efetivo da recolhedora. 


\subsection{Materiais e métodos}

\subsubsection{Material}

Os estudos e determinações de campo contidos neste estudo foram realizados no final da safra de 2001, em área pertencente ao grupo COSAN Usina Costa Pinto, localizada no município de Piracicaba, Estado de São Paulo. As coordenadas geográficas do centro da área de estudo são: Latitude $22^{\circ} 40^{\prime} 30^{\prime \prime}$ Sul, Longitude $47^{\circ} 36^{\prime} 38^{\prime \prime}$ Oeste e Altitude de 605 metros. O talhão possui área de 9,63ha com $6 \%$ de declividade e face de exposição Noroeste, com solo caracterizado como Latossolo Roxo. A variedade plantada foi a RB85 5113, em $2^{\circ}$ corte, no espaçamento de $1,40 \mathrm{~m}$, e com produtividade média de colmos de 108 t.ha $^{-1}$

\section{- Instrumentos para mensurações dimensionais e volumétricas}

Para determinações dos tempos dos ciclos operacionais da máquina estudada, foram utilizados dois cronômetros das marcas CASIO $^{{ }^{*}}$ e SPALDING ${ }^{\circledR}$ com capacidade de leitura 0,1s.

Célula de carga marca KIOWA ${ }^{\circledR}$, de capacidade máxima $1.000 \mathrm{~kg}$ e com capacidade de leitura de $10^{-1} \mathrm{~kg}$, acoplada a display com capacidade de leitura de $10^{-2} \mathrm{~kg}$.

Balança para pesagem da carga dos caminhões, com capacidade máxima de leitura de $30.000 \mathrm{~kg}$, e capacidade de leitura de $5 \mathrm{~kg}$, localizada no pátio da usina.

Dois caminhões (6X4) para transporte do palhiço recolhido, com capacidade volumétrica teórica de $55 \mathrm{~m}^{3}$.

Para as determinações do consumo de combustível foram utilizadas buretas graduadas, com capacidade volumétrica máxima de $1.000 \mathrm{~mL}$ e capacidade de leitura de 10mL.

\footnotetext{
* A citação de marcas neste trabalho não significa preferência do autor.
} 
As estimativas da quantidade de palhiço remanescente no solo após o recolhimento das leiras foram efetuadas utilizando-se um gabarito quadrado de metal com $1 \mathrm{~m}$ de lado.

Foram utilizados também outros utensílios, a saber: sacaria plástica, estacas, trenas, fita crepe, etiquetas, cordas, tripé metálico para suportar a célula de carga, latas de alumínio e fichas de campo.

\section{- Material para obtenção de dados laboratoriais}

Estufa marca FANEM ${ }^{\circledR}$, modelo 315SE, com regulagem de temperatura de $37^{\circ} \mathrm{C}$ a $220^{\circ} \mathrm{C}$.

Balança semi-analítica, marca METTLER ${ }^{\circledR}$, modelo P11, com capacidade de carga de $5 \mathrm{~kg}$ e capacidade de leitura de $10^{-4} \mathrm{~kg}$.

Foram utilizados também os seguintes equipamentos e materiais: sacos de papel kraft, fita, fichas de laboratório, canetas, peneiras, baldes, computadores.

\section{- Equipamentos objetos de estudo}

\section{A) Conjunto 1: enleirador + trator}

- Características do enleirador:

Marca e modelo: DMB, com 4 discos verticais (Apêndice 2A).

- Características do trator:

Marca e modelo: Ford 6610

Potência nominal: 65,4kW com rotação nominal de 2200rpm.

\section{B) Conjunto 2: enleirador + trator}

- Características enleirador: 
Marca e modelo: John Deere, Modelo 64 (Apêndice 2B).

- Características do trator:

Marca e modelo: MF 299

Potência nominal: 95,6kw, com rotação nominal de 2200 r.p.m.

\section{C) Recolhedora de forragem}

Marca e Modelo: John Deere, 6850 (Apêndice 4)

Motor: 6 cilindros, turbo, modelo JD 6125HZ001.

Potência máxima: 353kW a 2200rpm.

\subsubsection{Métodos}

Foram adotados dois tratamentos, T1 e T2, sendo que cada um utilizou um tipo de enleirador e mesma recolhedora de forragens, anteriormente caracterizados.

\section{- Caracterização das condições de campo}

\section{- Granulometria e umidade do solo}

Foram tomadas dez amostras de solo na profundidade de 0 a $5 \mathrm{~cm}$, casualizadamente, na área experimental. As amostras foram acondicionadas em recipientes metálicos, hermeticamente fechados, e levadas ao laboratório de máquinas agrícolas do Departamento de Engenharia Rural da ESALQ/USP, onde se utilizou do método gravimétrico padrão, com base na massa de solo seco em estufa à temperatura de $105-110^{\circ} \mathrm{C}$, para determinação de sua umidade.

Para determinação da granulometria do solo, utilizou-se o método Steel \& Bradfield (1934), que visa a obtenção da fração argila. A fração areia foi obtida a partir do peneiramento úmido (peneira 270, diâmetro de 0,053mm), seguido de fracionamento por peneiramento a seco. 


\section{- Tratamentos e repetições}

O recolhimento foi realizado considerando-se como tratamentos, as leiras feitas pelos dois conjuntos mecanizados responsáveis pelo enleiramento. Assim, as leiras formadas pelo conjunto 1 representaram o tratamento T1, e as leiras formadas pelo conjunto 2 representaram o tratamento T2.

Para efeito de entendimento, as operações de enleiramento e recolhimento apresentam diferentes ciclos operacionais. Para a operação de recolhimento, objeto deste estudo, considerou-se com um ciclo operacional o percurso da recolhedora necessário para completar a carga de um caminhão, sendo, portanto, de extensão variável, e dependente da quantidade de palhiço existente nas leiras. A extensão média do talhão no tratamento T1 foi de $374,5 \mathrm{~m}$, enquanto que no tratamento T2 a extensão média foi de $377,5 \mathrm{~m}$.

\section{- Tempos}

Durante a realização das repetições, cronometrou-se os tempos de cada ciclo operacional, ou seja, de cada repetição, considerando-se: tempos de percursos (efetivos); tempos de manobras; tempos de paradas eventuais (embuchamentos, detecção de metal, dentre outras) e tempos operacionais (efetivos + manobras + paradas eventuais). Desta forma, durante a operação de recolhimento do palhiço, todos os tempos foram considerados e anotados em planilha especifica.

\section{- Pesagem das cargas}

Cada unidade de transporte correspondente a um ciclo operacional (repetição) da recolhedora teve seu peso bruto e peso líquido da carga obtidos em balança nas instalações da Usina Costa Pinto, Grupo COSAN. Desta forma, os caminhões após o carregamento, ou seja, após o término de cada ciclo operacional, foram encaminhados até a Usina, distante cerca de $17 \mathrm{~km}$ da área experimental. 


\section{- Coleta de amostras de perdas}

Após a passagem da recolhedora de forragens sobre a área referente a cada ciclo operacional, foram coletadas 5 sub-amostras ao acaso, de perdas de palhiço, ou seja, em cada repetição, foram coletadas amostras do palhiço que permaneceu sobre o solo, ou seja, não recolhido pela recolhedora. Para isso, foi utilizado um quadrado de metal de $1 \mathrm{~m}^{2}$ lançado aleatoriamente sobre a área recolhida na repetição, e onde se encontrava cada leira. Todo o palhiço existente dentro deste quadrado foi recolhido (Apêndice 5), e pesado com o auxílio de um tripé e da célula de carga. Esse material foi identificado e vedado em sacos plásticos. Devido às condições de umidade do solo, o palhiço mais úmido, aderido ao solo, foi desconsiderado.

\section{- Determinações laboratoriais}

\section{- Palhiço}

Todas as amostras de palhiço coletadas no campo foram pesadas em célula de carga, ensacadas e vedadas, com a finalidade de obter-se o peso úmido do material colhido, ou seja, o peso do material em condições de campo.

As determinações de umidade (UPRem - \%), peso seco (PRemSS t.ha ${ }^{-1}$ ) e terra (TL - \%) seguiram o fluxograma apresentado na Figura 1. 


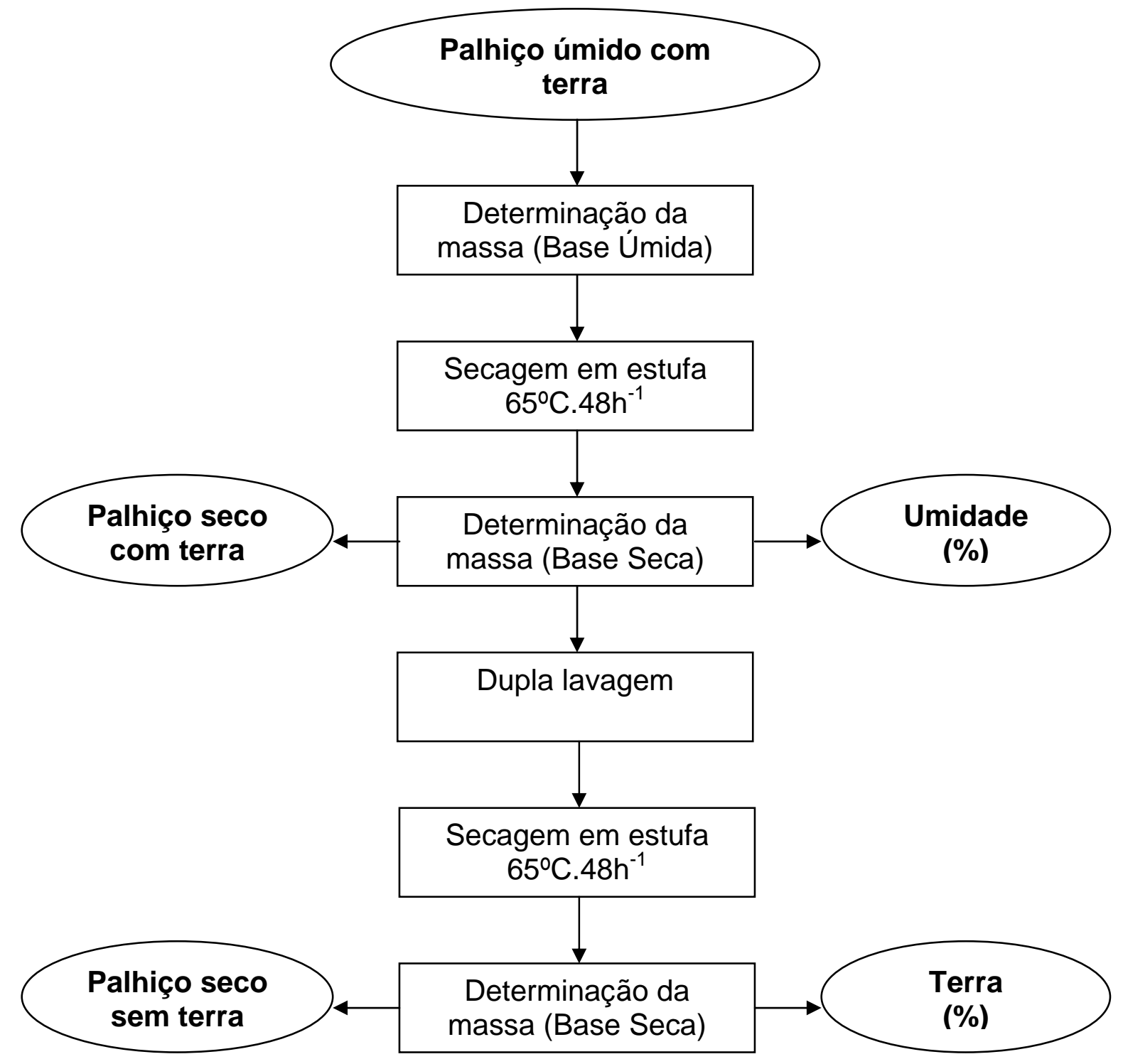

Figura 10 - Fluxograma das determinações de palhiço seco sem terra, umidade e terra

As amostras de perdas recolhidas no solo foram transferidas para sacos de papel kraft e colocadas em estufa durante 48 horas a temperatura de $65^{\circ} \mathrm{C}$, com a finalidade de se obter o peso seco do palhiço + terra.

Desta forma, após retiradas da estufa as amostras foram pesadas novamente, determinando-se assim a sua umidade em função da massa em base úmida do material, de acordo com a Equação 12. 
$U P \operatorname{Re} m(\%)=\left(\frac{M U-M S}{M U}\right) \times 100$

Sendo:

MU = Massa úmida;

MS = Massa seca;

UPRem (\%) = Umidade do palhiço.

Em seguida, com a finalidade de se determinar a percentagem de terra presente nas amostras de palhiço remanescente, procedeu-se a lavagem das amostras. Para tanto, efetuou-se uma dupla lavagem do palhiço em baldes com água limpa. Para quantificar, com maior exatidão, a quantidade de terra presente nas amostras, a água utilizada em ambas as lavagens do material e que continha partículas de palhiço era peneirada, e o palhiço remanescente nas peneiras, adicionado à amostra.

Após a lavagem, as amostras foram novamente ensacadas em sacos de papel kraft identificados e levadas à estufa por mais 48 horas com temperatura de $65^{\circ} \mathrm{C}$.

As amostras foram retiradas da estufa e novamente pesadas, para a determinação do peso seco do palhiço limpo, sem terra.

\section{- Variáveis consideradas}

\section{A) Produtividade do palhiço}

Corresponde a quantidade de palhiço total existente sobre o solo na área experimental, calculada pela somatória do palhiço remanescente sobre o solo e o palhiço recolhido pela recolhedora de forragens (Equação 13).

$$
P P=(P \operatorname{Re} m U T+P \operatorname{Re} c U T)
$$

Sendo:

$\mathrm{PP}=$ Produtividade do palhiço $\left(\right.$ t.ha $\left.^{-1}\right)$;

PremUT = Palhiço remanescente úmido com terra (t.ha $\left.{ }^{-1}\right)$; 
PrecUT = Palhiço recolhido úmido com terra $\left(\right.$ t.ha $\left.{ }^{-1}\right)$.

\section{B) Palhiço recolhido úmido com terra}

É a quantidade de palhiço por hectare recolhida pela recolhedora de forragens, obtida através da razão entre a carga líquida de palhiço em cada caminhão (repetição) e a área correspondente a cada repetição (Equação 14).

$$
P \operatorname{Re} c U T=\left[\left(\frac{C L C a m}{1000}\right) \div A \operatorname{Re} p\right]
$$

Sendo:

PRecUT = Palhiço recolhido úmido com terra $\left(\mathrm{t}^{\mathrm{h}} \mathrm{h}^{-1}\right)$;

CLCam = Carga líquida caminhão (t.repetição ${ }^{-1}$ );

Arep = Área repetição $\left(\right.$ ha.repetição $\left.{ }^{-1}\right)$.

\section{C) Palhiço remanescente úmido com terra}

É a quantidade de palhiço que permaneceu sobre o solo após a passagem da recolhedora. Para a obtenção desta variável, realizou-se a extrapolação para 1ha, dos valores de palhiço encontrados nas amostras recolhidas em $1 \mathrm{~m}^{2}$.

\section{D) Palhiço remanescente seco sem terra}

As amostras de palhiço recolhidas em $1 \mathrm{~m}^{2}$ após as determinações laboratoriais, foram extrapoladas para 1ha, obtendo-se, assim, o palhiço remanescente seco e sem terra.

\section{E) Velocidades efetiva e operacional da recolhedora}

A velocidade efetiva da recolhedora considerou a razão entre 0 percurso e o tempo efetivo da operação de recolhimento, conforme a Equação 15.

$$
V E \operatorname{Re} c=\left(\frac{P E}{T E}\right) \times 3,6
$$


Sendo:

VERec $=$ Velocidade efetiva média do recolhimento $\left(\mathrm{km} \cdot \mathrm{h}^{-1}\right)$;

$\mathrm{PE}=$ Percurso efetivo por repetição $(\mathrm{m})$;

$\mathrm{TE}=$ Tempo efetivo por repetição (s).

Quanto à velocidade operacional do recolhimento, foi utilizada a Equação 16.

$$
V O \operatorname{Re} c=(P O / T O) \times 3,6
$$

Sendo:

VORec $=$ Velocidade operacional do recolhimento $\left(\mathrm{km} \cdot \mathrm{h}^{-1}\right)$;

$\mathrm{PO}=$ Percurso operacional por repetição $(\mathrm{m})$;

TO = Tempo operacional por repetição (s).

\section{F) Capacidade efetiva da operação de recolhimento}

A capacidade efetiva da operação de recolhimento foi obtida considerando-se o palhiço recolhido em cada repetição (carga líquida do caminhão correspondente a cada repetição) e o tempo efetivo necessário para o recolhimento deste material. Como é possível observar na Equação 17, é necessário considerar a eficácia de manipulação da recolhedora.

CAPE Re $c=\left[\left(\frac{C L i q}{T E}\right) \times 3,6\right] \times E F M$

Sendo:

CAPERec $=$ Capacidade efetiva de recolhimento $\left(\right.$ t. $\left.^{-1}\right)$;

CLiq = Carga líquida em cada caminhão, correspondente a o palhiço recolhido em uma repetição $\left(\mathrm{t}^{-1}\right)$;

$\mathrm{TE}=$ Tempo efetivo necessário para o recolhimento do palhiço necessário para completar uma carga ou repetição (s).

EFM = Eficácia de manipulação (\%). 


$$
E F M=\left[\frac{P \operatorname{Re} c}{(P \operatorname{Re} c+P \operatorname{Re} m)}\right] \times 100
$$

Sendo:

EFM = Eficácia de manipulação (\%);

PRec $=$ Palhiço recolhido $\left(\right.$ t.ha $\left.{ }^{-1}\right)$;

PRem = Palhiço remanescente sobre o solo $\left(\right.$ t.ha $\left.^{-1}\right)$.

\section{G) Capacidade operacional da operação de recolhimento}

Para calcular a capacidade operacional da operação de recolhimento, utilizou-se o mesmo princípio da capacidade de campo efetiva, considerando-se, entretanto, na Equação 19, todos os tempos envolvidos na operação de recolhimento. Também para esta variável, foi utilizada a eficácia de manipulação.

$$
\text { CAPORe } c=\left\{\left[\left(\frac{C L i q}{T O}\right) \times 3,6\right] \times E F M\right\}
$$

(19)

\section{H) Consumo efetivo e operacional do recolhimento}

Os consumo efetivo e operacional foram calculados tendo por base 0 consumo de combustível em cada repetição, e as capacidades efetiva e operacional da operação de recolhimento, segundo as Equações 20 e 21.

$$
C E \operatorname{Re} c=\frac{\left\{C \operatorname{Re} p \times\left[\left[\left(\frac{P E}{P O}\right) \div T E\right] \times 3,6\right]\right\}}{C A P E \operatorname{Re} c}
$$

Sendo:

CERec $=$ Consumo efetivo recolhimento $\left(L . t^{-1}\right)$;

CRep = Consumo na repetição $\left(\right.$ L.repetição $\left.0^{-1}\right)$;

$\mathrm{PE}=$ Percurso efetivo (m.repetição $\left.{ }^{-1}\right)$;

$\mathrm{PO}=$ Percurso operacional $\left(\mathrm{m} \cdot\right.$ repetição $\left.^{-1}\right) ;$

$\mathrm{TE}=$ Tempo efetivo $\left(\right.$ s.repetição $\left.{ }^{-1}\right)$;

CAPERec $=$ Capacidade efetiva de recolhimento $\left(\right.$ t. $\left.^{-1}\right)$. 
CORe $c=\left[\frac{C \operatorname{Re} p \times(1 / A \operatorname{Re} p)}{C A P O \operatorname{Re} c}\right]$

Sendo:

CORec = Consumo operacional recolhimento $\left(\right.$ L. $\left.\mathrm{t}^{-1}\right)$;

CRep = Consumo na repetição $\left(\right.$ L.repetição $\left.{ }^{-1}\right)$;

ARep = Área da repetição $\left(\mathrm{m}^{2}\right)$;

CAPORec $=$ Capacidade operacional do recolhimento $\left(\mathrm{t} \cdot \mathrm{h}^{-1}\right)$.

\section{I) Eficiência de campo}

A variável eficiência de campo da operação de recolhimento foi obtida pela da razão entre as capacidades de campo operacional e efetiva, conforme apresentado na Equação 22.

$$
E F \operatorname{Re} c=\left[\left(\frac{C A P E \operatorname{Re} c}{C A P O \operatorname{Re} C}\right) \times 100\right]
$$

Sendo:

EFRec = Eficciência de campo (\%);

CAPERec $=$ Capacidade efetiva do recolhimento $\left(\mathrm{t} . \mathrm{h}^{-1}\right)$;

CAPORec $=$ Capacidade operacional do recolhimento $\left(\mathrm{t} . \mathrm{h}^{-1}\right)$.

\section{J) Terra no palhiço remanescente}

A percentagem de terra presente no palhiço remanescente foi calculada a partir da extrapolação para um hectare, da quantidade de terra, em gramas, presente nas amostras de $1 \mathrm{~m}^{2}$. 


\subsection{Resultados e discussão}

$\mathrm{Na}$ análise granulométrica do solo, foram encontrados teores de $28,34 \%$ de argila, $23,33 \%$ de silte e $47,83 \%$ de areia e, com relação a umidade, o tratamento T1 apresentou valor médio de $15,85 \%$ enquanto que o tratamento T2 apresentou média de 17,98\%, com diferença significativa entre as médias.

Tabela 15. Resumo estatístico da operação de recolhimento de palhiço de canade-açúcar à granel

\begin{tabular}{|c|c|c|c|c|}
\hline \multirow{2}{*}{ Variáveis } & \multicolumn{4}{|c|}{ Tratamentos } \\
\hline & $\mathrm{T} 1$ & $\mathrm{Cv}$ & $\mathrm{T} 2$ & $\mathrm{cv}$ \\
\hline PP (t.ha $\left.{ }^{-1}\right)$ & $23,09^{a}$ & 6,56 & $25,18^{a}$ & 8,58 \\
\hline PRecUT (t.ha ${ }^{-1}$ ) & $13,96^{\mathrm{a}}$ & 12,45 & $15,24^{\mathrm{a}}$ & 10,87 \\
\hline PRemUT (t.ha ${ }^{-1}$ ) & $9,13^{\mathrm{a}}$ & 15,46 & $9,93^{a}$ & 29,25 \\
\hline PRemSS (t.ha ${ }^{-1}$ ) & $4,22^{\mathrm{a}}$ & 11,71 & $4,20^{a}$ & 38,57 \\
\hline $\operatorname{VERec}\left(\mathrm{km} \cdot \mathrm{h}^{-1}\right)$ & $2,92^{\mathrm{a}}$ & 19,69 & $1,70^{b}$ & 18,41 \\
\hline $\operatorname{VORec}\left(\mathrm{km} \cdot \mathrm{h}^{-1}\right)$ & $2,44^{\mathrm{a}}$ & 16,84 & $1,66^{b}$ & 17,93 \\
\hline CAPERec $\left(\mathrm{t} . \mathrm{h}^{-1}\right)$ & $11,41^{\mathrm{a}}$ & 40,13 & $11,13^{\mathrm{a}}$ & 16,95 \\
\hline CAPORec $\left(\right.$ t. $\left.h^{-1}\right)$ & $8,77^{\mathrm{a}}$ & 16,48 & $10,22^{\mathrm{a}}$ & 16,24 \\
\hline CERec $\left(\right.$ L.t. $\left.{ }^{-1}\right)$ & $2,59^{\mathrm{a}}$ & 24,61 & $2,87^{\mathrm{a}}$ & 14,16 \\
\hline $\operatorname{CORec}\left(\right.$ L.t $\left.^{-1}\right)$ & $3,34^{\mathrm{a}}$ & 14,39 & $3,29^{a}$ & 12,94 \\
\hline EFRec (\%) & $81,00^{a}$ & 15,97 & $91,97^{\mathrm{a}}$ & 1,37 \\
\hline TRem (\%) & $7,74^{\mathrm{a}}$ & 32,48 & $7,56^{a}$ & 25,83 \\
\hline
\end{tabular}


Tabela 15. Resumo estatístico da operação de recolhimento de palhiço de canade-açúcar à granel

\begin{tabular}{lcccc}
\hline \multirow{2}{*}{ Variáveis } & \multicolumn{4}{c}{ Tratamentos } \\
& $\mathrm{T} 1$ & $\mathrm{cv}$ & $\mathrm{T} 2$ & $\mathrm{cv}$ \\
\hline UPRem (\%) & $32,79^{\mathrm{b}}$ & 6,04 & $42,10^{\mathrm{a}}$ & 4,54 \\
CRec $\left(\mathrm{R} \$ . \mathrm{EBP}^{-1}\right)$ & 3,79 & - & 3,97 & - \\
\hline
\end{tabular}

${ }^{a, b}$ Médias seguidas de letras diferentes apresentam diferenças significativas. PP= produtividade do palhiço ; PRemUT= palhiço remanescente úmido com terra; PRemSS= palhiço remanescente seco sem terra; VMRec= velocidade média do recolhimento; CAPERec $=$ Capacidade Efetiva; CAPORec $=$ Capacidade Operacional; $\mathrm{CERec}=$ Consumo Efetivo; $\mathrm{CORec}=$ Consumo Operacional; EFRec= Eficiência de Campo; TRem= terra no palhiço remanescente; UPRem= umidade do palhiço remanescente; $\mathrm{CRec}=$ custo

\subsubsection{Produtividade do palhiço}

Utilizando-se as médias de produtividade do palhiço em cada tratamento, apresentadas na Tabela 15 obtém-se a média estimada de palhiço úmido na área experimental, de 24,13 t.ha ${ }^{-1}$. A comparação entre o valor da produtividade média do palhiço com informações obtidas por outros autores confirma a existência de variabilidade elevada com relação a esta variável, como é possível observar na Figura 11. 


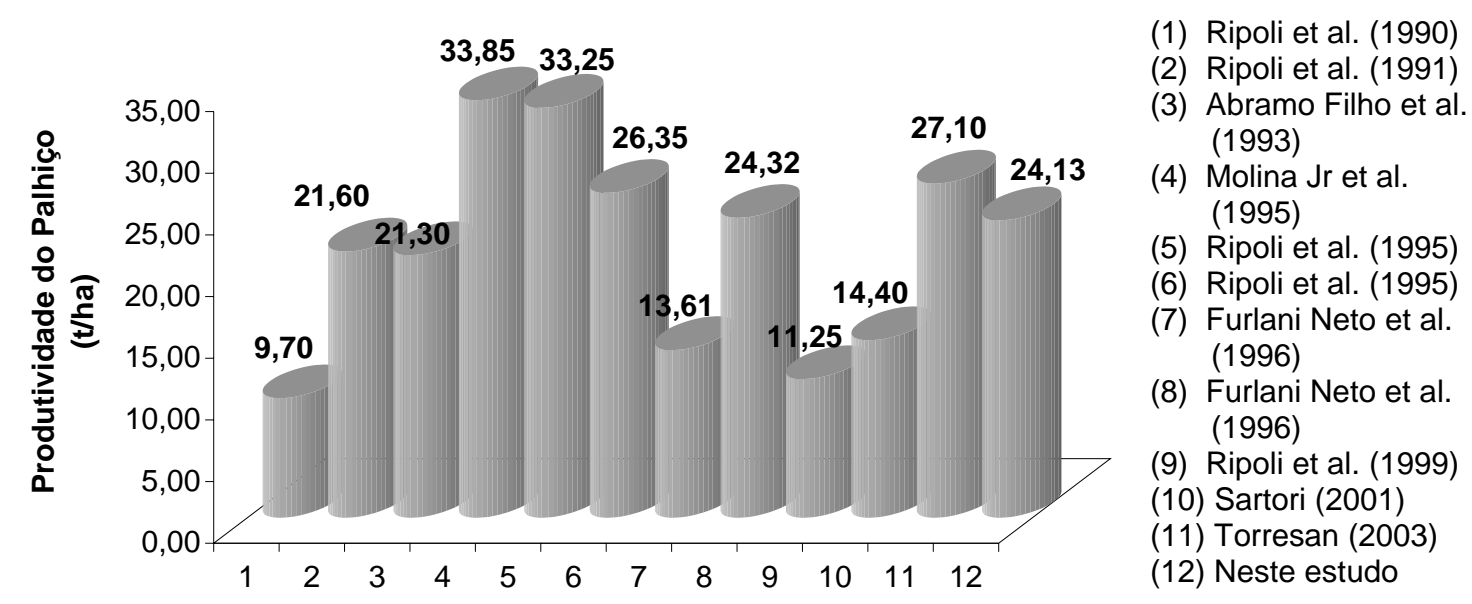

Figura 11 - Produtividade do palhiço - comparação relativa entre diversos estudos

Desta forma, observam-se valores compreendidos entre 9,7t.ha ${ }^{-1}$ a 33,85 t.ha ${ }^{-1}$, com coeficiente de variação de $36,76 \%$. Com base na Figura 11 , é possível perceber que devido a esta grande variabilidade na produtividade de palhiço, os valores encontrados neste estudo podem ser considerados coerentes, uma vez que se encontram próximos a média obtida de 21,52 t.ha ${ }^{-1}$.

Na Figura 12, estão apresentados os histogramas de produtividade do palhiço na área experimental.

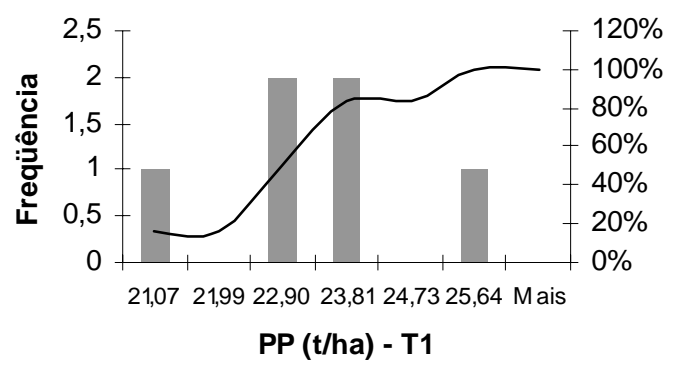

Frequência $\%$ cumulativo

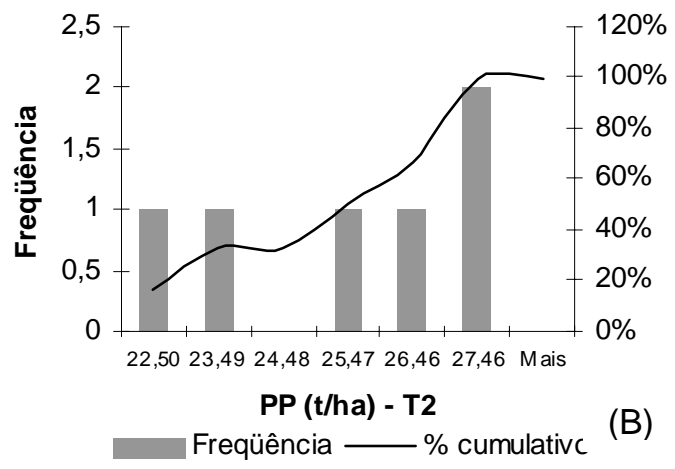

Figura 12 - Histograma da produtividade do palhiço na área experimental. (A) Tratamento 1. (B) Tratamento 2. PP= produtividade do palhiço 
Observa-se nos histogramas que o tratamento $\mathrm{T} 1$ apresentou assimetria positiva, o que significa que a média $\left(23,09\right.$ t.ha $\left.^{-1}\right)$ dos dados está localizada à esquerda do centro da figura, e $83,33 \%$ das observações encontram-se entre 21,07 e 23,81 t.ha ${ }^{-1}$. O tratamento T2, por sua vez apresenta assimetria negativa, uma vez que sua média $\left(25,17 \mathrm{t}^{-h a^{-1}}\right)$ é inferior a sua mediana. A assimetria permite verificar a existência de valores extremos dentro de um conjunto de dados, e sua posição em relação à média. Em termos de distribuição dos dados, $66,67 \%$ das observações encontram-se situadas nos intervalos 25,47 a 27,46 t.ha ${ }^{-1}$. Com base nessas informações, é possível verificar a irregularidade de distribuição do palhiço sobre o solo, uma vez que em uma mesma área, sob as mesmas condições de declividade e variedade, cada repetição apresentou produtividade variável dentro de um mesmo tratamento. Entretanto, não houve diferença estatística significativa entre as médias para esta variável.

\subsubsection{Palhiço remanescente}

Quando se discute a retirada do palhiço das áreas de produção de cana-de-açúcar para sua utilização na co-geração de energia, é importante considerar as vantagens agronômicas da manutenção de uma camada de cobertura vegetal sobre o solo. Isto justifica a não retirada da totalidade de palhiço produzido no campo, e sua quantificação em base úmida e base seca com e sem terra agregada.

$\mathrm{Na}$ Tabela 15, pode-se observar o resumo estatístico para as variáveis palhiço remanescente úmido com terra (PRemUT) e palhiço remanescente seco sem terra (PRemSS). Para ambas as variáveis não houve diferença estatística significativa, confirmando assim que tipo de enleirador não influenciou o total de palhiço remanescente no campo, ou seja, a recolhedora deixou sobre o solo quantidades semelhantes de material em ambos os tratamentos. 
$\mathrm{Na}$ Figura 13, apresenta-se o gráfico referente às quantidades de palhiço remanescente úmido com terra e palhiço remanescente seco sem terra para os dois tratamentos.

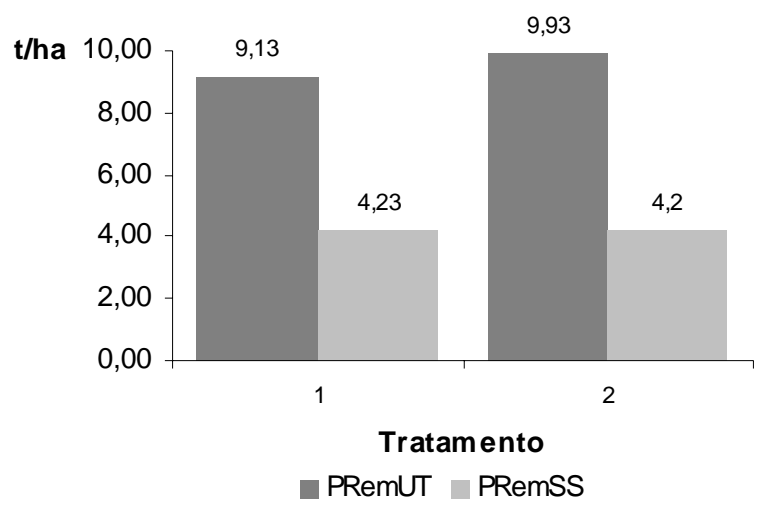

Figura 13 - Comparação entre palhiço remanescente úmido com terra e palhiço remanescente seco sem terra para tratamento T1 e T2. PRemUT= palhiço remanescente úmido com terra; $\mathrm{PRemSS}=$ palhiço remanescente seco sem terra

$\mathrm{Na}$ Figura 13, pode-se observar que, apesar dos valores diferentes apresentados dentro de cada tratamento, para ambas as variáveis, o comportamento foi semelhante, ou seja, a umidade e percentagem de terra presente corresponderam a mais de $50 \%$ da massa total considerada em quase todas as amostras dos dois tratamentos. Cabe ressaltar que a idéia defendida por alguns autores, dos benefícios trazidos pela permanência de parte do palhiço sobre o solo foi mantida, com 4,22 t.ha ${ }^{-1}$ de palhiço seco no tratamento T1 e 2,20t.ha ${ }^{-1}$ no tratamento $\mathrm{T} 2$.

\subsubsection{Velocidade de deslocamento da recolhedora}

Na Figura 15 estão apresentados os dados obtidos na determinação da velocidade de trabalho da recolhedora de forragens operando sobre as leiras previamente formadas. 

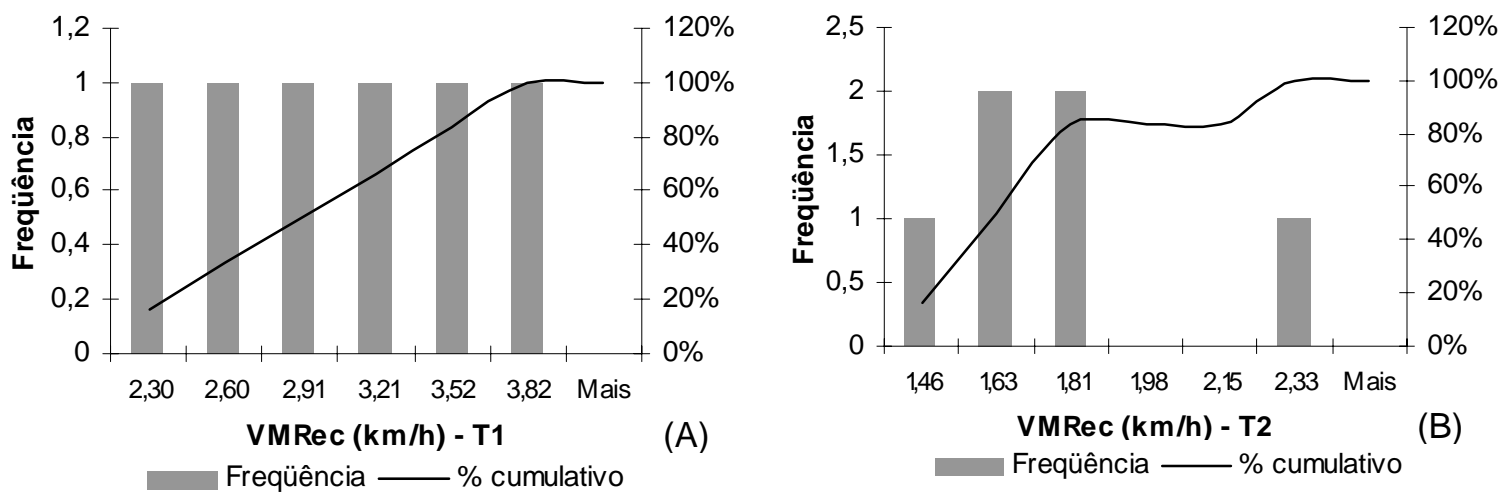

Figura 14 - Histogramas da velocidade média de recolhimento. (A) Tratamento 1.

(B) Tratamento 2. VMRec= velocidade média

O tratamento T1 apresentou velocidade média de 2,92 km. ${ }^{-1}$, enquanto que o tratamento T2 teve velocidade média de $1,70 \mathrm{~km} . \mathrm{h}^{-1}$, sendo que estes valores apresentaram diferenças estatísticas significativas ao nível de 5\% de probabilidade. No tratamento T1, houve uma maior variação da velocidade, uma vez que cada repetição apresentou velocidades distintas, variando de 2,30 a $3,82 \mathrm{~km} \cdot \mathrm{h}^{-1}$. No tratamento T2, esta variação foi menor, com 83,33\% das observações concentradas entre 1,46 e 1,81 km. $\mathrm{h}^{-1}$, ou seja, dentro de uma faixa com variação de apenas $0,35 \mathrm{~km} \cdot \mathrm{h}^{-1}$, bem inferior a faixa de $1,52 \mathrm{~km} \cdot \mathrm{h}^{-1}$ apresentado pelo tratamento T1.

\subsubsection{Capacidade Efetiva e Operacional da recolhedora e Eficiência de Campo}

Como é possível verificar na Tabela 14, as Capacidades Efetivas de ambos os tratamentos foram semelhantes, não apresentando diferenças significativas entre si. Já para a Capacidade Operacional, o tratamento T2 apresentou valor maior $\left(10,22 \mathrm{ha} \cdot \mathrm{h}^{-1}\right)$ do que o tratamento T1 $\left(8,77 \mathrm{ha} \cdot \mathrm{h}^{-1}\right)$. Entretanto, também para esta variável o Teste $\mathrm{F}$ para análise da variância não 
indicou diferença estatística significativa. A Eficiência de Campo, dada pela razão entre a Capacidade Operacional e Efetiva foi de 80,99\% para o tratamento T1, devido a Capacidade Operacional deste tratamento ter sido relativamente baixa quando comparada a Capacidade Operacional do tratamento T2. Esta baixa Capacidade Operacional do tratamento T1 foi ocasionada por problemas de embuchamento durante a operação de recolhimento. Em três repetições desse tratamento, ocorreram paradas provocadas pelo embuchamento, devidas à maior velocidade do tratamento $\mathrm{T} 1$, ocasionando uma taxa de alimentação inadequada na plataforma de recolhimento.

\subsubsection{Consumo Operacional e Efetivo da recolhedora}

$\mathrm{Na}$ Figura 15 estão apresentados os histogramas de Consumo Operacional da recolhedora de forragens.
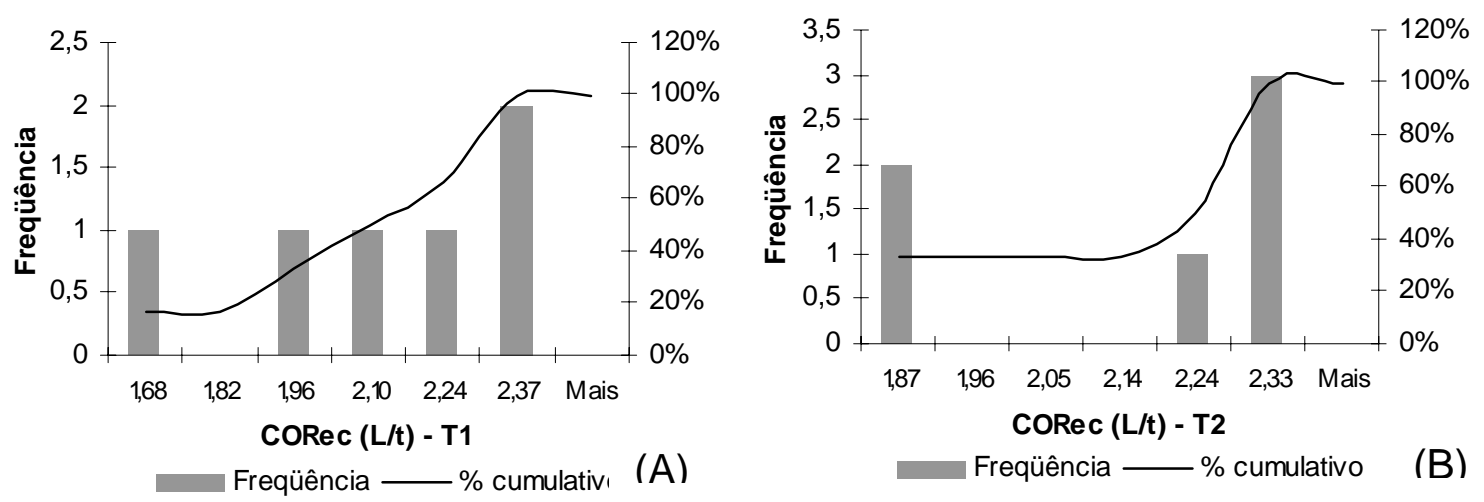

Figura 15 - Histogramas do Consumo Operacional de combustível na operação de recolhimento. (A) Tratamento 1. (B) Tratamento 2. CORec= Consumo Operacional

O histograma apresentado na Figura 15 (A) possui curva de freqüência com assimetria negativa, e tipo de curva em forma de $\mathrm{J}$, com ponto de ordenada máxima ocorrendo na extremidade direita. O histograma do tratamento T2 também possui assimetria negativa e curva em forma de J. A variação do Consumo Operacional dentro de cada tratamento é originada pela maior ou 
menor exigência, pelo motor, de combustível para que o recolhimento das quantidades variáveis de palhiço ao longo da leira correspondente a cada ciclo operacional.

No tratamento T2, 66,67\% das observações encontram-se entre as classes de 2,24 e 2,33L.t ${ }^{-1}$, enquanto que no tratamento T1 50\% das observações situam-se nesta faixa. O Consumo Operacional de combustível na operação de recolhimento do palhiço apresentou médias de 2,08 L. $t^{-1}$ para o tratamento $\mathrm{T} 1$ e 2,14L.t $\mathrm{t}^{-1}$ para o tratamento $\mathrm{T} 2$, valores esses que não apresentaram diferença estatística significativa quando analisados pelo Teste $\mathrm{F}$ de análise da variância. Desta forma, pode-se dizer que para ambos os tratamentos, o consumo de combustível foi semelhante.

Na Figura 16, estão apresentados os histogramas com os dados referentes ao Consumo Efetivo da recolhedora de forragem.
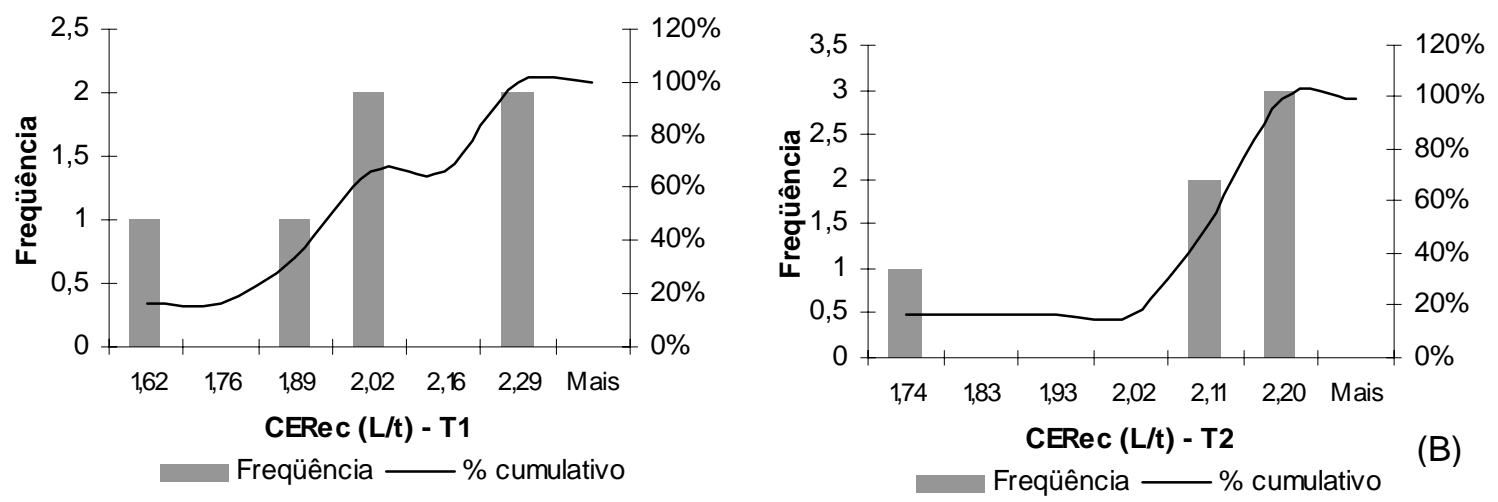

Figura 16 - Histogramas de Consumo Efetivo de combustível no recolhimento. (A) Tratamento 1. (B) Tratamento 2. CERec= Consumo Efetivo

O tratamento T1 apresentou assimetria negativa, e sua curva de freqüência encontrou-se sob a forma bimodal, pois apresentou dois máximos ou picos. Já no tratamento T2 o histograma apresentou assimetria negativa, porém com curva de freqüência em forma de $J$, pois o ponto máximo ocorreu na sua 
extremidade direita. Pode-se observar que para o tratamento T1, 66,67\% das observações encontraram-se acima da média (1,98L.t $\left.{ }^{-1}\right)$. Para o tratamento T2, 83,33\% das observações encontram-se acima da média (2,07L. $\left.\mathrm{t}^{-1}\right)$, ficando evidente neste caso, que apenas uma observação foi responsável pela diminuição da média desta variável neste tratamento. Mais uma vez, a causa provável dessa variação de consumo de combustível dentro dos tratamentos, foi ocasionada pelas leiras formadas pelos conjuntos mecanizados anteriormente estudados.

\subsubsection{Percentagem de terra no palhiço remanescente}

A percentagem de terra presente no palhiço remanescente (TL \%) é apresentada na Figura 17, com seus valores distribuídos em classes nos respectivos histogramas.
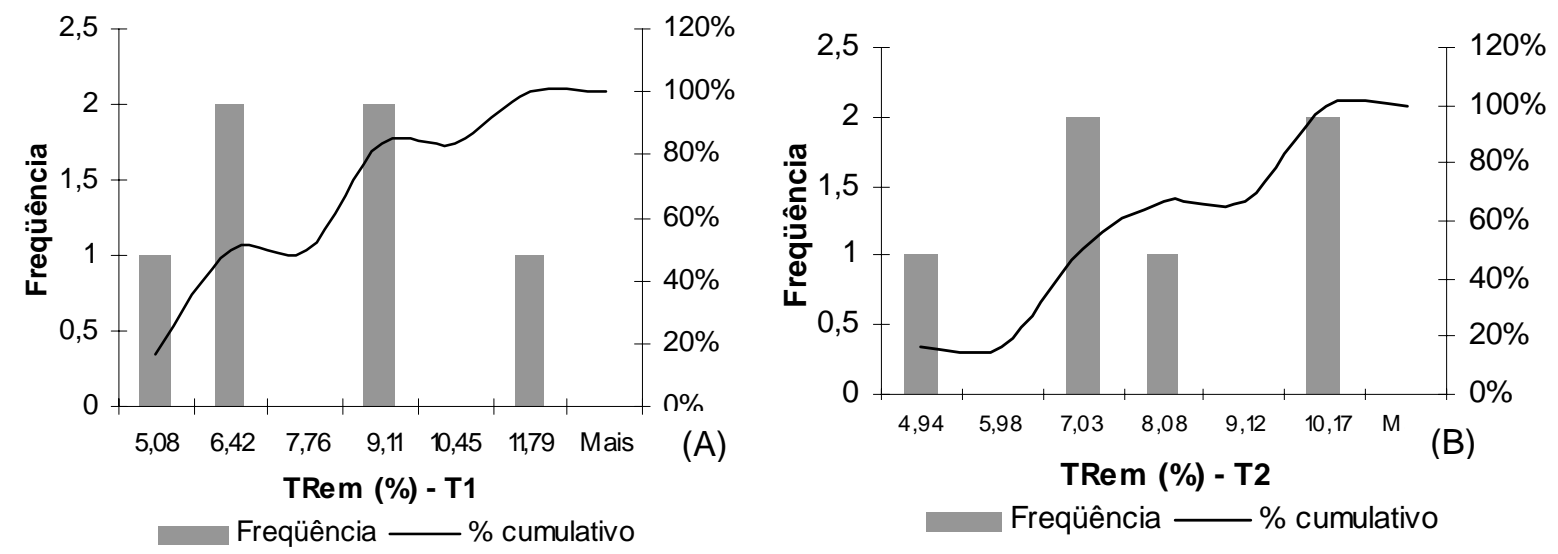

Figura 17 - Percentagem de terra presente no palhiço remanescente. (A) Tratamento 1. (B) Tratamento 2. TRem= terra no palhiço remanescente

A estatística descritiva dos dados referentes a percentagem de terra presente no palhiço remanescente mostra que as curvas de distribuição de freqüência nos tratamentos é classificada como bimodal, por apresentar dois 
máximos, e apresentam assimetria positiva. Esses picos, no tratamento T1 correspondem às classes de $6,42 \%$ e $9,11 \%$, que concentram $66,67 \%$ dos valores encontrados. Para o tratamento $\mathrm{T} 2$, nos picos, encontrados nas classes de 7,03 e $10,17 \%$, estão $66,67 \%$ dos dados. As médias dos dois tratamentos para esta variável foram $7,74 \%$ e $7,55 \%$, ou seja, não apresentaram diferença estatística significativa no Teste $\mathrm{F}$ para análise da variância. As percentagens variáveis de terra presentes no palhiço remanescente dentro de cada tratamento têm origem na variação da umidade e também são função do maior ou menor arraste de impurezas minerais pelo ancinho enleirador.

\subsubsection{Custo do recolhimento}

O custo da operação de recolhimento do palhiço enleirado foi fornecido pela Usina Costa Pinto - Grupo COSAN, com o valor de R\$9,17. $\mathrm{t}^{-1}$, sendo possível calcular o custo em $\mathrm{R} \$ . \mathrm{EBP}^{-1}$. 
Tabela 16. Custo em $\mathrm{R} \$ . E B P^{-1}$ da operação de recolhimento para cada tratamento

\begin{tabular}{lcc}
\hline Tratamentos & T1 & T2 \\
\hline Custos $\left(\mathrm{R} \$ . \mathrm{EBP}^{-1}\right)$ & 3,79 & 3,98 \\
\hline
\end{tabular}

A diferença apresentada pelos tratamentos ao utilizar-se $R \$$.EBP ${ }^{-1}$ se deve a diluição dos custos quando se adota a energia como padrão de comparação, e assim, o tratamento T2 por ter apresentado maior umidade do palhiço, possui menor poder calorífico útil do que o tratamento T1. 


\subsection{Conclusões}

A análise dos dados obtidos permite concluir que:

- A quantidade total de palhiço existente no canavial teve valores semelhantes em ambos os tratamento;

- Não houve diferença significativa no desempenho operacional da recolhedora, quando considerados os parâmetros estudados neste trabalho. Assim, aceita-se a hipótese de trabalho, ou seja, o tipo de enleirador não influenciou o desempenho da recolhedora. 


\section{CARACTERIZAÇÃO DO PALHIÇO DE CANA-DE-AÇÚCAR COLHIDO E POSTO NA USINA}

\subsection{Introdução}

Os estudos referentes à sistemas de recolhimento de palhiço de cana-deaçúcar requerem a caracterização física dessa biomassa, deve-se quantificar o palhiço recolhido bem como determinar aa quantidade de terra agregada ao material recolhido e o custo total do sistema de recolhimento, seja desde o enleiramento até o descarregamento na usina.

Esta caracterização se torna necessária por fornecer parâmetros que possibilitem a análise detalhada do sistema de recolhimento, verificando assim sua viabilidade econômica.

Este estudo teve por objetivo caracterizar o palhiço previamente enleirado por dois tipos de enleiradores e recolhido por uma recolhedora de forragens, e determinar seu custo total, posto na usina, tendo como hipótese de trabalho a não influência do tipo de enleirador utilizado, nas características do palhiço recolhido, considerando-se a definição apresentada por Ripoli et al. (2003) para essa biomassa. 


\subsection{Material e métodos}

\subsubsection{Material}

\section{- Condições de campo}

Os estudos e determinações de campo contidos neste estudo foram realizados no final da safra de 2001, em área pertencente ao grupo COSAN Costa Pinto, localizada no município de Piracicaba, Estado de São Paulo. As coordenadas geográficas do centro da área de estudo são: Latitude $22^{\circ} 40^{\prime} 30^{\prime \prime}$ Sul, Longitude $47^{\circ} 36$ '38' Oeste e Altitude de 605 metros. O talhão possui área de 9,63ha com $6 \%$ de declividade e face de exposição Noroeste, com solo caracterizado como Latossolo Roxo. A variedade plantada foi a RB85 5113, em $2^{\circ}$ corte, no espaçamento de $1,40 \mathrm{~m}$, e com produtividade média de colmos de 108 t.ha $^{-1}$

\section{- Instrumentos para mensurações dimensionais, ponderais e volumétricas}

Para determinações dos tempos de percursos das máquinas, foram utilizados dois cronômetros das marcas CASIO $^{{ }^{*}}$ e SPALDING ${ }^{\circledR}$ com capacidade de leitura $0,1 \mathrm{~s}$.

Célula de carga marca KIOWA ${ }^{\circledR}$, de capacidade máxima $1.000 \mathrm{~kg}$ e com capacidade de leitura de $10^{-1} \mathrm{~kg}$, acoplada a display para leituras dos valores fornecidos, com capacidade de leitura de $10^{-2} \mathrm{~kg}$.

Balança para pesagem da carga dos caminhões, com capacidade máxima de leitura de $30.000 \mathrm{~kg}$ e capacidade de leitura de $5 \mathrm{~kg}$, localizada no pátio da usina.

Dois caminhões (6X4) para transporte do palhiço recolhido, com capacidade volumétrica teórica média de $52 \mathrm{~m}^{3}$.

Para as determinações do consumo de combustível foram utilizadas buretas graduadas, com capacidade volumétrica máxima de $1.000 \mathrm{~mL}$ e capacidade de leitura de $10 \mathrm{~mL}$.

\footnotetext{
${ }^{*}$ A citação de marcas neste trabalho não significa preferência do autor.
} 
Além de outros utensílios, a saber: sacaria plástica, estacas, trenas, fita crepe, etiquetas, canetas, cordas, tripé metálico para suportar a célula de carga, latas de alumínio e fichas de campo.

- Material para obtenção de dados laboratoriais

Estufa marca FANEM ${ }^{\circledR}$, modelo $315 \mathrm{SE}$, com regulagem de temperatura de $37^{\circ} \mathrm{C}$ a $220^{\circ} \mathrm{C}$.

Balança semi-analítica, marca METTLER ${ }^{\circledR}$, modelo P11, com capacidade de carga de $5 \mathrm{~kg}$ e capacidade de leitura de $10^{-4} \mathrm{~kg}$.

Foram utilizados também os seguintes equipamentos e materiais: sacos de papel kraft, fita, fichas de laboratório, peneiras, baldes, computadores.

- Equipamentos objetos de estudo

A) Conjunto 1: enleirador + trator

- Características do enleirador:

Marca e modelo: DMB, com 4 discos verticais (Apêndice 2A).

- Características do trator:

Marca e modelo: Ford 6610

Potência nominal: 65,4kW com rotação nominal de 2200rpm.

B) Conjunto 2: enleirador + trator

- Características enleirador:

Marca e modelo: John Deere, Modelo 64 (Apêndice 2B).

- Características do trator: 
Marca e modelo: MF 299

Potência nominal: 95,6kw, com rotação nominal de 2200 rpm.

\section{C) Recolhedora de forragem}

Marca e Modelo: John Deere, 6850 (Apêndice 4).

Motor: 6 cilindros, turbo, modelo JD 6125HZOO1.

Potência máxima: 353kW com rotação nominal de 2200rpm.

\subsubsection{Métodos}

- Caracterizações e determinações de campo

\section{- Umidade e granulometria do solo}

Foram tomadas cinco amostras de solo, casualizadamente, na área de cada tipo de enleiramento, na profundidade 0 a $5 \mathrm{~cm}$, com a finalidade de obterse o tipo de solo e seu grau de umidade no momento das operações de enleiramento. As amostras foram acondicionadas em recipientes metálicos hermeticamente fechados e levados ao laboratório de máquinas agrícolas do Departamento de Engenharia Rural ESALQ/USP, onde utilizou-se o método gravimétrico padrão, com base na massa de solo seco em estufa à temperatura de 105-110 graus centígrados.

Para a determinação da granulometria do solo, utilizou-se o método Steel \& Bradfield (1934), que visa a obtenção da fração argila. A fração areia foi obtida a partir do peneiramento úmido (peneira 270, diâmetro de 0,053mm), seguido de fracionamento por peneiramento a seco.

\section{- Tratamentos e repetições}

Foram realizados ensaios utilizando-se dois conjuntos de trator mais enleirador. O enleiramento, em ambos os tratamentos, foi o "enleiramento duplo", que consiste na formação de uma leira composta por meio de duas passadas do 
ancinho (ida e volta). O recolhimento foi efetuado com seis repetições para cada tratamento, considerando-se cada repetição o percurso da recolhedora necessário para que se completasse a carga de uma unidade de transporte.

\section{- Tempos}

Durante a realização das repetições, cronometrou-se o tempo de cada ciclo operacional, considerando-se: tempo de percurso (efetivo); tempo de manobra; tempo operacional (efetivo + manobra) e outros tempos (embuchamento, parada devida ao detector de metal, componente este, existente na colhedora).

\section{- Massa específica do palhiço no transporte}

Cada caminhão correspondente a um ciclo operacional (repetição) da recolhedora teve seu peso bruto e peso líquido da carga obtidos em balança localizada no pátio da Usina Costa Pinto - Grupo COSAN.

\section{- Coleta de amostras de palhiço}

Com a finalidade de obtenção umidade e terra presentes no material recolhido, após o término de cada ciclo operacional da recolhedora, foram retiradas cinco amostras de palhiço da carga de cada unidade de transporte, aleatoriamente. Essas amostras foram acondicionadas em sacos plásticos, identificadas de acordo com o tratamento e repetição a que pertenciam e imediatamente vedadas, para evitar perda umidade.

\section{- Eficácia de manipulação}

Eficácia de Manipulação (Ripoli, 1996), é a relação entre a quantidade de matéria-prima existente e recolhida pela máquina, sendo o parâmetro que qualifica a operação de retirada da matéria-prima do campo. Quanto este indicador, melhor o desempenho da máquina, refletindo, em termos práticos, a quantidade de palhiço que deixou de ser levado para a usina. 


\section{- Determinações laboratoriais}

As amostras coletadas nos caminhões foram ensacadas, vedadas e, posteriormente, pesadas no laboratório de Máquinas Agrícolas do Departamento de Engenharia Rural - ESALQ/USP, com a finalidade de obter-se o peso do material em condições de campo (úmido).

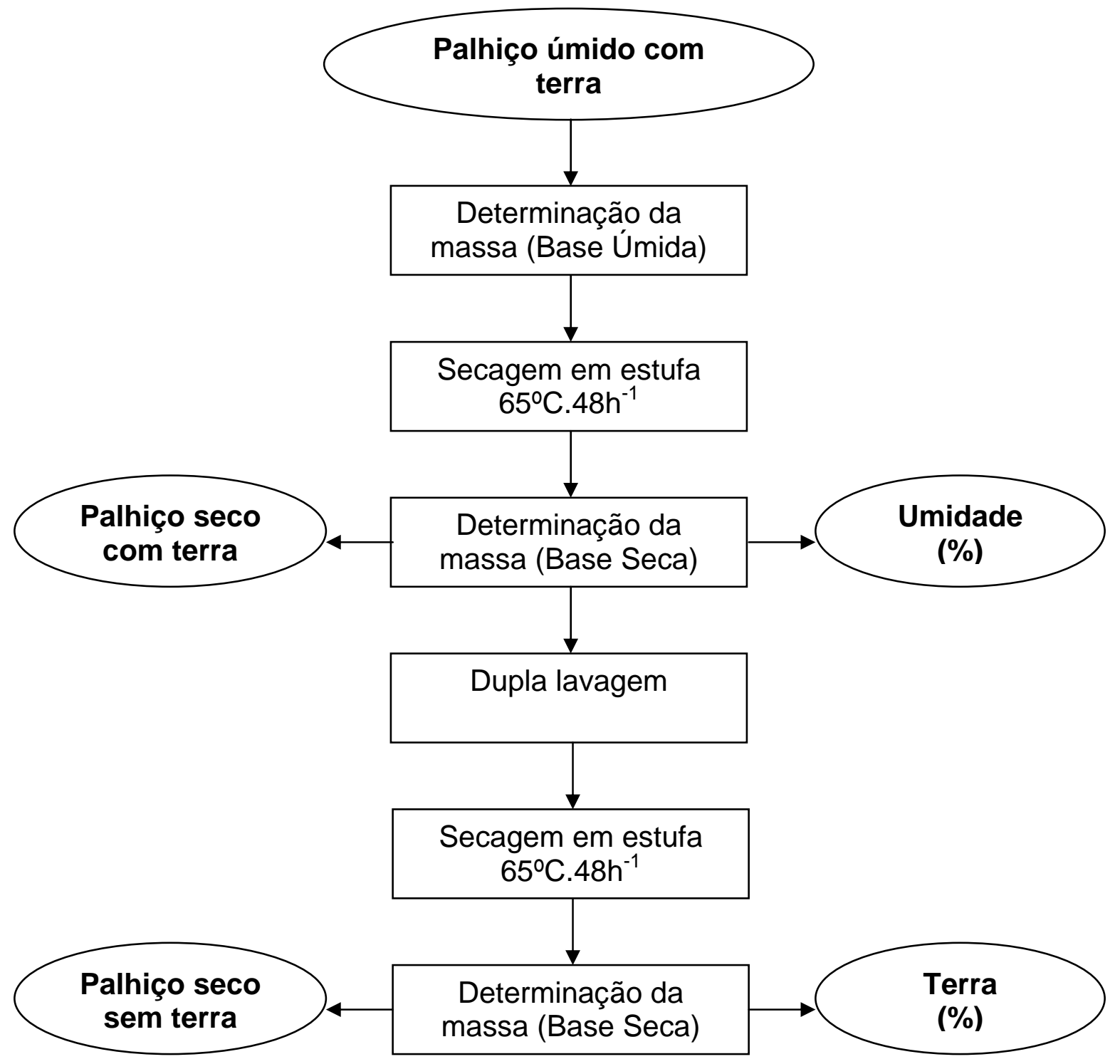

Figura 18 - Fluxograma: determinações de palhiço seco sem terra, umidade e terra 
As amostras foram transferidas para sacos de papel kraft e colocadas em estufa durante 48 horas a temperatura de $65^{\circ} \mathrm{C}$, com a finalidade de se obter o peso seco do palhiço + terra.

Desta forma, depois de retiradas da estufa as amostras foram pesadas novamente, determinando-se assim, a sua umidade em função da massa em base úmida do material, de acordo com a Equação 23.

$$
U P \operatorname{Rec}(\%)=\left[\left(\frac{M U-M S}{M U}\right) \times 100\right]
$$

Sendo:

MU = Massa úmida;

MS = Massa seca;

UPRec (\%) = Umidade do palhiço.

Em seguida, com a finalidade de se determinar a percentagem de terra presente tanto nas cargas enviadas à usina, quanto quantificar a percentagem presente nas amostras de perdas, procedeu-se a lavagem das amostras para retirar a terra. Para tanto, efetuou-se uma dupla lavagem do palhiço em baldes com água limpa. Para quantificar, com maior exatidão, a quantidade de terra presente nas amostras, a água com material particulado, utilizada em ambas as lavagens do material foi peneirada, e o palhiço remanescente nas peneiras, adicionado à amostra.

Após a lavagem, as amostras foram novamente ensacadas em sacos de papel kraft identificados e levadas à estufa por mais 48 horas com temperatura de $65^{\circ} \mathrm{C}$.

As amostras foram retiradas da estufa e, novamente pesadas, para a determinação do peso seco do palhiço limpo, sem terra. 


\section{- Variáveis consideradas}

\section{A) Palhiço recolhido úmido com terra}

A quantidade de palhiço úmido com terra recolhido durante a coleta dos dados de campo foi determinada por meio da pesagem dos caminhões correspondentes a cada repetição, e a extrapolação deste valor para um hectare, conform a Equação 24.

$$
P \operatorname{Re} c U T=[(C \text { Liq } / \text { AR }) \div 1000]
$$

Sendo:

PRecTU = Palhiço recolhido úmido com terra $\left(\mathrm{t}^{\mathrm{h}} \mathrm{h}^{-1}\right)$;

CLiq = Carga líquida do caminhão (t.repetição $\left.{ }^{-1}\right)$;

$\mathrm{AR}=$ Área da repetição (ha.repetição ${ }^{-1}$ ).

\section{B) Palhiço recolhido seco sem terra}

Para a obtenção dos valores correspondentes a esta variável, após os procedimentos laboratoriais de lavagem e secagem das amostras, a massa seca e sem terra de palhiço correspondente a cada amostra era extrapolada considerando-se a massa total recolhida por hectare (palhiço + água + terra).

\section{C) Terra no palhiço recolhido}

Para a determinação da quantidade de terra existente no palhiço recolhido em cada hectare, a quantidade obtida em laboratório, correspondente a cada amostra era extrapolada considerando-se a massa total de palhiço recolhida em cada hectare. 


\section{D) Massa específica do palhiço}

Para se determinar a massa específica do palhiço recolhido a granel foi necessário considerar a capacidade volumétrica da carroceria do caminhão utilizado no transporte deste material, conforme a Equação 25.

$$
C p v=A \times L \times P
$$

Sendo:

Cpv = Capacidade volumétrica $\left(\mathrm{kg} \cdot \mathrm{m}^{-3}\right)$;

A = Altura da carroceria $(m)$;

$\mathrm{L}=$ Largura da carroceria $(\mathrm{m})$;

$\mathrm{P}=$ comprimento da carroceria $(\mathrm{m})$.

A massa específica foi calculada considerando-se a massa de palhiço transportada em cada caminhão, ou seja, em cada repetição, conforme a Equação 26.

$$
M E=(C L i q / C p v)
$$

Onde:

ME = Massa específica $\left(\mathrm{kg} \cdot \mathrm{m}^{-3}\right)$;

CLiq = Carga líquida do caminhão $(\mathrm{kg})$;

Cpv = Capacidade volumétrica $\left(\mathrm{m}^{3}\right)$.

\section{E) Energia por hectare}

Esta variável é função da quantidade de palhiço seco e sem terra recolhido por hectare, e de seu poder calorífico útil, conforme a Equação 27.

$$
E n=(P \operatorname{Re} c S S \times P C U)
$$


Sendo:

En = Energia $\left(\right.$ EBP $\cdot$ ha $\left.^{-1}\right)$;

PrecSS $=$ Palhiço recolhido seco sem terra $\left(\right.$ t.ha $\left.{ }^{-1}\right)$;

PCU $=$ Poder calorífico útil do palhiço recolhido (EBP.t $\left.\mathrm{t}^{-1}\right)$.

\section{F) Eficácia de manipulação}

A eficácia de manipulação da recolhedora foi determinada pela Equação 28.

$$
E F M=\left[\frac{P \operatorname{Re} c U T}{(P \operatorname{Re} c U T+P \operatorname{Re} m U T)}\right] \times 100
$$

Sendo:

EFM = Eficácia de manipulação (\%);

PRecUT = Palhiço recolhido úmido com terra (t.ha $\left.{ }^{-1}\right)$;

PRemUT = Palhiço remanescente úmido com terra (t.ha $\left.{ }^{-1}\right)$.

\section{G) Custo transporte}

Os valores referentes ao custo do transporte foram obtidos junto ao Grupo COSAN.

\section{H) Custo Total}

O custo total foi determinado pela somatória de todos os custos envolvidos no sistema e fornecidos pelo Grupo COSAN. 


\subsection{Resultados e discussão}

$\mathrm{Na}$ análise granulométrica do solo, foram encontrados teores de $28,34 \%$ de argila, $23,33 \%$ de silte e $47,83 \%$ de areia, e com relação a umidade, o tratamento T1 apresentou valor médio de 15,85\% enquanto que o tratamento T2 apresentou umidade média de 17,98\%. A análise estatística das médias de umidade do solo confirmou a existência de diferença significativa entre as médias, ao nível de 5\% de probabilidade.

As variáveis analisadas neste estudo estão apresentadas, com suas respectivas médias e coeficientes de variação (cv), na Tabela 17. 
Tabela 17. Resumo estatístico das variáveis estudas

\begin{tabular}{|c|c|c|c|c|}
\hline \multirow{2}{*}{ Variáveis } & \multicolumn{4}{|c|}{ Tratamentos } \\
\hline & $\mathrm{T} 1$ & $\mathrm{cV}$ & T2 & $\mathrm{cV}$ \\
\hline PRecUT (t.ha ${ }^{-1}$ ) & $13,96^{\mathrm{a}}$ & 12,45 & $15,24^{\mathrm{a}}$ & 10,87 \\
\hline PRecSS (t.ha $\left.{ }^{-1}\right)$ & $8,37^{\mathrm{a}}$ & 10,72 & $8,40^{\mathrm{a}}$ & 10,75 \\
\hline TRec (\%) & $6,46^{\mathrm{a}}$ & 23,22 & $8,38^{a}$ & 47,58 \\
\hline UPRec (\%) & $33,40^{\mathrm{a}}$ & 11,57 & $36,37^{\mathrm{a}}$ & 13,30 \\
\hline$P \cup C(t)$ & $4,64^{\mathrm{a}}$ & 10,50 & $4,81^{\mathrm{a}}$ & 8,94 \\
\hline $\mathrm{PSC}(\mathrm{t})$ & $2,79^{\mathrm{a}}$ & 9,31 & $2,66^{\mathrm{a}}$ & 11,58 \\
\hline $\operatorname{ME}\left(\mathrm{kg} \cdot \mathrm{m}^{-3}\right)$ & $278,46^{a}$ & 12,45 & $304,04^{a}$ & 10,87 \\
\hline En (EBP.ha $\left.{ }^{-1}\right)$ & $20,49^{\mathrm{a}}$ & 15,78 & $17,55^{\mathrm{a}}$ & 10,39 \\
\hline EFM (\%) & $60,40^{\mathrm{a}}$ & 9,60 & $61,00^{\mathrm{a}}$ & 14,58 \\
\hline Ctransp (R\$.EBP $\left.{ }^{-1}\right)$ & 3,68 & - & 3,85 & - \\
\hline Cdesc $\left(\mathrm{R} \$ . \mathrm{EBP}^{-1}\right)$ & 0,87 & - & 0,91 & - \\
\hline CTotal $\left(\mathrm{R} \$ . \mathrm{t}^{-1}\right)$ & 21,38 & - & 20,67 & - \\
\hline CTotal $\left(\mathrm{R} \$ . \mathrm{EBP}^{-1}\right)$ & 8,83 & - & 8,97 & - \\
\hline
\end{tabular}

a,b Médias seguidas de letras diferentes apresentam diferenças significativas. PRecUT = palhiço recolhido úmido com terra; $\mathrm{PRecSS}=$ palhiço recolhido seco sem terra; TRec= terra no palhiço recolhido; UPRec= umidade do palhiço recolhido; $\mathrm{PUC}=$ palhiço úmido na unidade de transporte; $\mathrm{PSC}=$ palhiço seco na unidade de transporte; $\mathrm{ME}=$ massa específica do palhiço na unidade de transporte; $E n=$ energia no palhiço; EFM= eficácia de manipulação; CTransp= custo do transporte; $\mathrm{CDesc}=$ custo do descarregamento; CTotal= custo total 


\subsubsection{Palhiço recolhido}

Na Figura 19, estão apresentados os histogramas com a distribuição dos dados referentes ao palhiço recolhido úmido com terra, em toneladas por hectare.
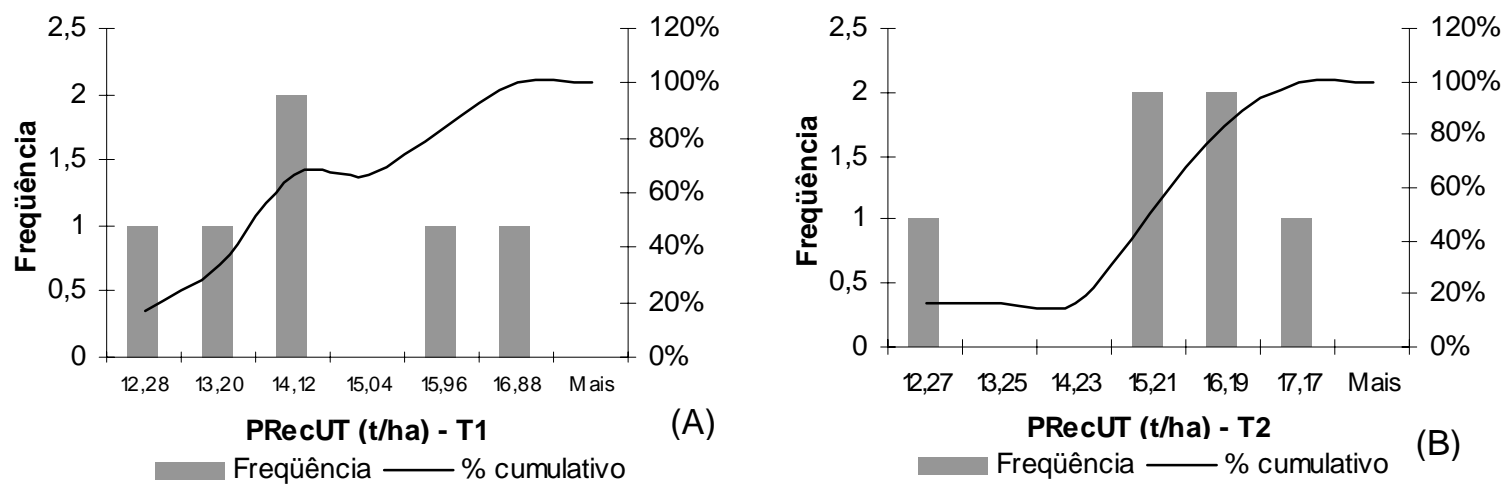

Figura 19. Palhiço recolhido úmido com terra $\left(\right.$ t.ha $\left.{ }^{-1}\right)$. (A) Tratamento 1. (B) Tratamento 2. PRecUT= palhiço recolhido úmido com terra.

No tratamento T1, a média de palhiço úmido com terra recolhido foi de 13,96 t.ha ${ }^{-1}$, e no tratamento T2 foi 15,24 t.ha $^{-1}$, valores esses que no Teste $F$ para análise da variância não indicaram diferenças significativas. Os histogramas apresentados na Figura 3 permitem observar que o tratamento T1 apresentou assimetria positiva, enquanto que o tratamento T2, apresentou assimetria negativa. Observa-se que o tratamento T1 apresentou distribuição mais uniforme de seus dados, quando comparado ao tratamento $\mathrm{T} 2$, onde uma única observação, concentrada na classe mais inferior do histograma (B), diminuiu o valor da média.

Neste estudo, os enleiradores utilizados não provocaram diferenças significativas nas quantidades de palhiço recolhido, apesar de terem ocorrido embuchamentos no tratamento T1 que podem ter prejudicado esta operação. 
Devido a ausência de trabalhos baseados em recolhimento de palhiço de cana-de-açúcar à granel, para que fosse possível a realização de uma comparação entre a quantidade de material recolhido neste estudo e por outros autores, foram utilizadas pesquisas realizadas com recolhimento deste material através do uso de enfardadoras.

O gráfico apresentado na Figura 20 compara os resultados obtidos por diversos autores trabalhando com palhiço enfardado e a média obtida neste estudo.

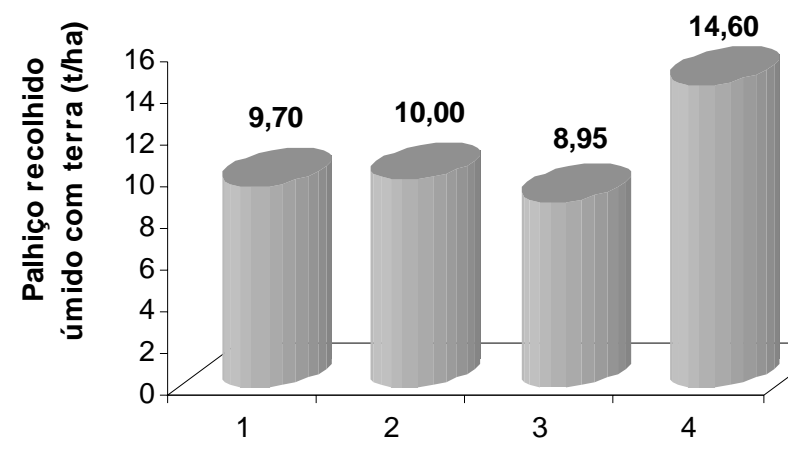

(1) Ripoli et al. (1990)

(2) Ripoli (2001)

(3) Ripoli (2002)

(4) Neste estudo (2003)

Figura 20 - Quantidade de palhiço úmido com terra recolhido - comparação entre diversos autores

Quando se estuda sistemas de recolhimento de palhiço de cana-deaçúcar, uma das variáveis de maior importância é a quantidade de palhiço recolhido, descontando-se a umidade e a percentagem de terra presentes nesta biomassa. Este valor é a base para cálculos que envolvem a determinação da viabilidade econômica do sistema.

$\mathrm{Na}$ Figura 21, estão apresentados os histogramas referentes a distribuição dos valores obtidos em laboratório da variável palhiço recolhido seco sem terra em toneladas por hectare. 

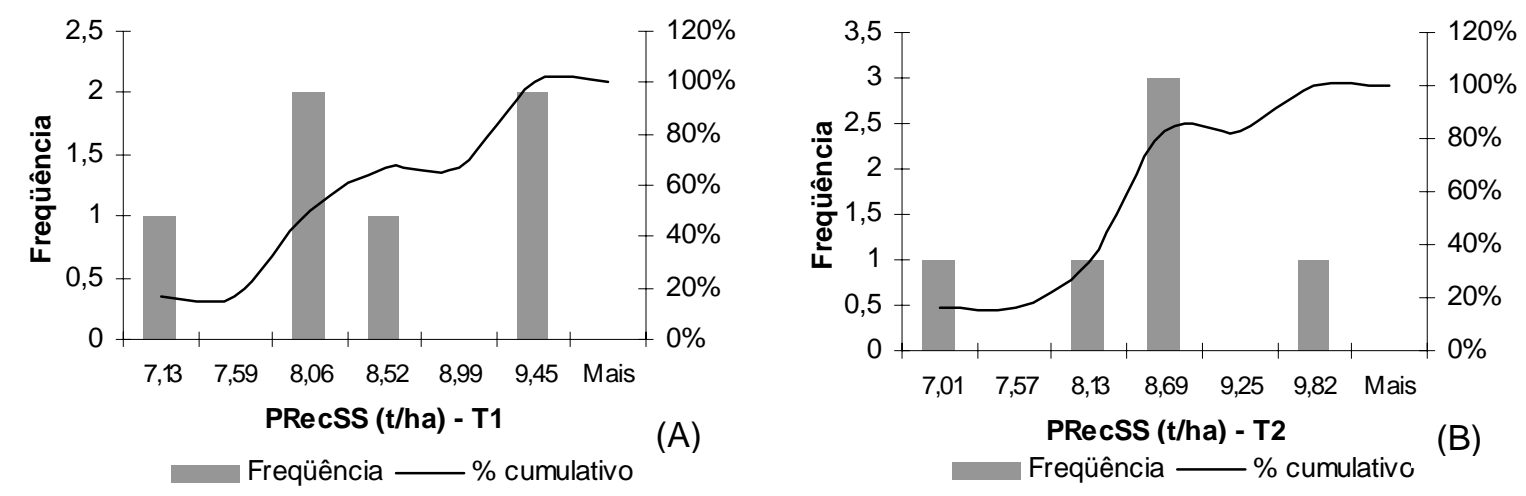

Figura 21 - Palhiço recolhido seco sem terra $\left(\right.$ t.ha $\left.{ }^{-1}\right)$. (A) Tratamento 1. (B) Tratamento 2. PRecSS= palhiço recolhido seco sem terra

As médias obtidas para esta variável foram de 8,37 e 8,40 t.ha ${ }^{-1}$, para os tratamentos T1 e T2 respectivamente, não havendo diferenças estatísticas significativas entre ambas. Na verdade, as curvas de distribuição dos dados em ambos os histogramas apresentam comportamento relativamente semelhante, com assimetria positiva para os dois tratamentos. As diferenças apresentadas dentro de cada tratamento quando se compara o palhiço úmido (Figura 20) e palhiço seco (Figura 21), demonstram claramente a existência de repetições com maior umidade do palhiço.

\subsubsection{Percentagem de terra no palhiço recolhido}

$\mathrm{Na}$ Figura 22, estão apresentados os histogramas referentes aos dados da variável percentagem de terra no palhiço recolhido. 

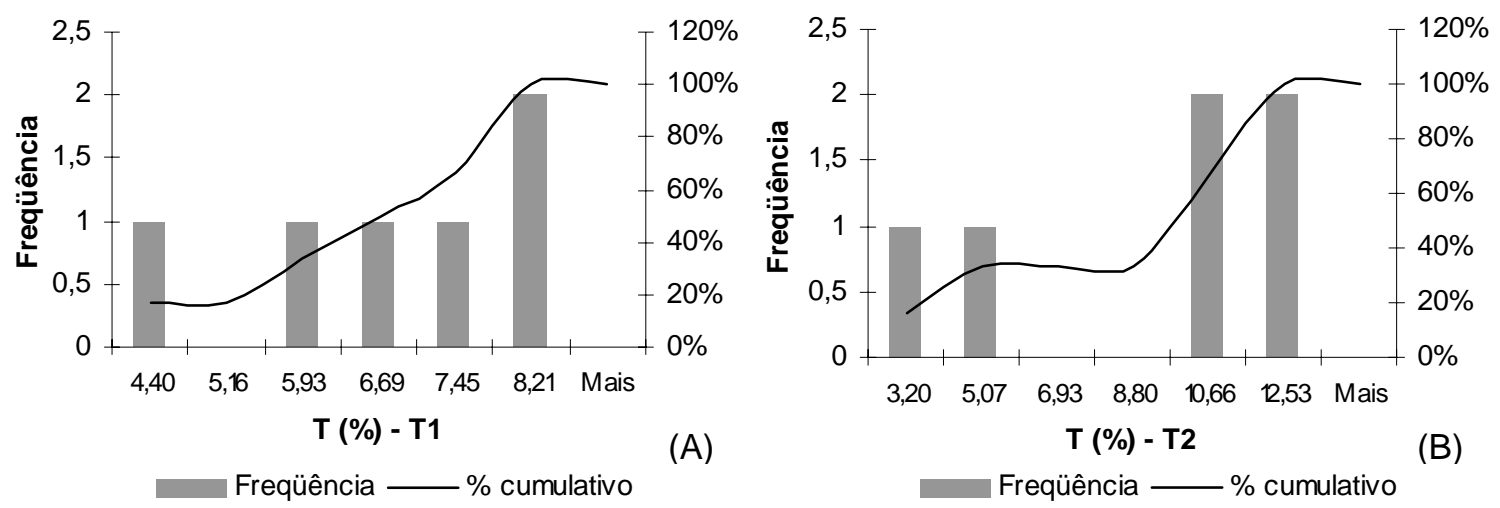

Figura 22 - Percentagem de terra no palhiço recolhido (\%). (A) Tratamento 1. (B) Tratamento 2. TRec= terra no palhiço recolhido

As médias encontradas neste estudo para a variável percentagem de terra presente no palhiço recolhido foram de 6,46\% para o tratamento T1 e 8,38\% para o tratamento T2, e apesar dos valores distintos, não houve, pelo Teste $\mathrm{F}$ para análise da variância, diferença estatística entre eles. O coeficiente de variação (cv) para esses tratamentos pode ser considerado segundo Gomes (1990), como alto para o tratamento T1 $(23,22 \%)$ e muito alto para o tratamento T2 (47,58\%). Esses elevados coeficientes de variação se devem a amplitude apresentada entre os valores obtidos para cada repetição dos tratamentos. Assim, no tratamento T1 as classes de freqüência vão de 4,40 a 8,21\% e no tratamento T2, de 3,20 a 12,53\%. Em termos de caracterização dos histogramas, ambos os tratamentos apresentam assimetria negativa.

Mais uma vez, essas variações dentro dos tratamentos foram provocadas pelas diferenças nas características de cada conjunto mecanizado responsável pelo enleiramento do palhiço, uma vez que a maior quantidade de terra está relacionada ao maior arraste deste constituinte pelo enleirador e a maior retenção dessas impurezas quando o palhiço apresenta umidade mais elevada. 
$\mathrm{Na}$ Figura 23, apresenta-se os dados obtidos na bibliográfica consultada com relação a percentagem de terra presente no palhiço, traçando-se um comparativo com a média encontrada neste estudo. Cabe ressaltar que mais uma vez devido a ausência de trabalhos com palhiço a granel, os dados apresentados dizem respeito a estudos de enfardamento de palhiço.

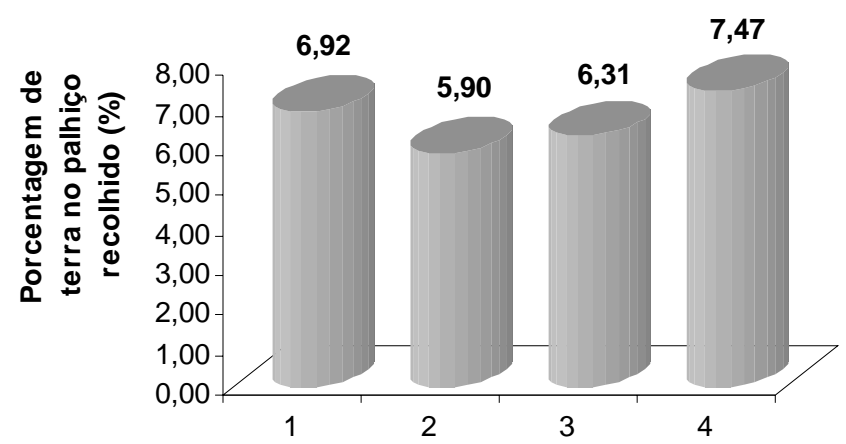

(1) Abramo Filho at al. (1993)

(2) COPERSUCAR (1998)

(3) Torrezan (2003)

(4) Neste estudo (2003)

Figura 23 - Percentagem de terra no palhiço recolhido - comparação entre diversos autores

Como é possível observar na Figura 23, os valores encontrados para a percentagem de terra no palhiço recolhido são variáveis, sendo que a média encontrada no presente trabalho está acima daquelas obtidas tanto por Abramo Filho et al. (1993), COPERSUCAR (1998) e Torrezan (2003). Estes autores utilizaram o enfardamento de palhiço enleirado em seus estudos.

\subsubsection{Umidade do palhiço recolhido}

Após os procedimentos laboratoriais de lavagem e secagem do palhiço, calculou-se a umidade (\%) presente no palhiço recolhido e posto na usina. Assim, para o tratamento T1, a média para esta variável foi 33,40\% com coeficiente de variação médio (11,57\%), enquanto que o tratamento T2 apresentou média de $36,37 \%$ com coeficiente de variação também médio $(13,30 \%)$. Não houve diferença estatística significativa entre as médias, ou seja, 
junto do palhiço recolhido os tratamentos estão levando para as usinas mais de $30 \%$ de água.

\subsubsection{Eficácia de Manipulação}

Na Figura 24, estão apresentados os histogramas referentes a eficácia de manipulação da operação de recolhimento do palhiço enleirado.
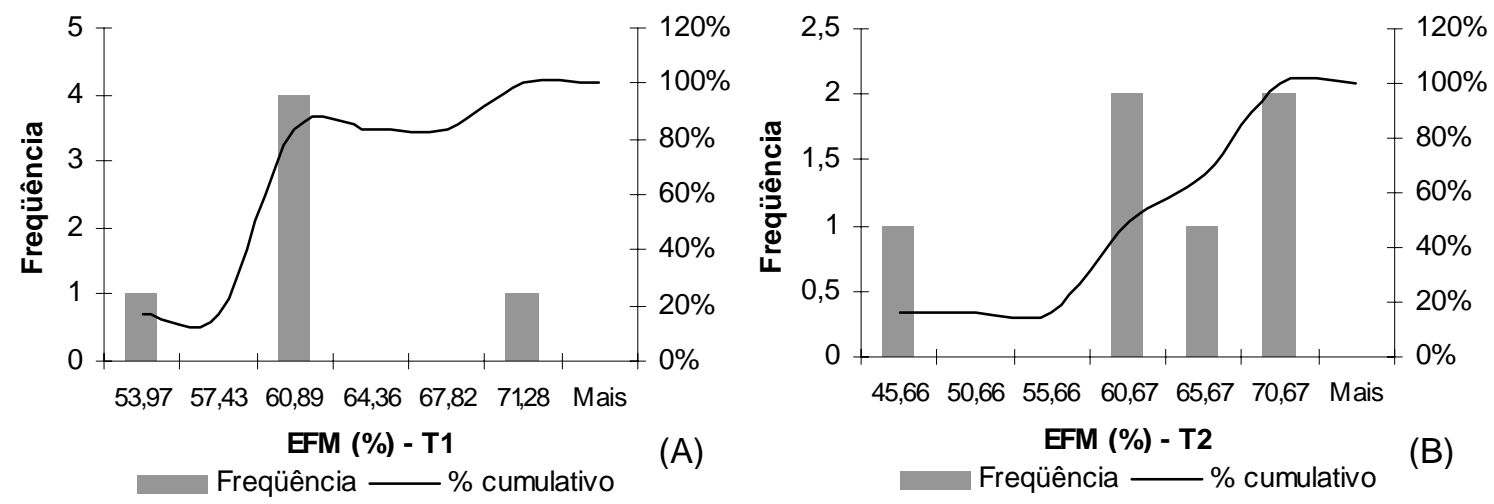

Figura 24 - Eficácia de manipulação (\%). (A) Tratamento 1. (B) Tratamento 2. EFM= Eficácia de Manipulação

O Teste $F$ para análise da variância não apresentou diferenças significativas para esta variável, sendo que T1 apresentou média de 60,40\% e T2 61,05\%.. Em termos de coeficiente de variação (cv), o tratamento T1 apresenta valor considerado baixo $(9,60 \%)$, enquanto que o tratamento T2 teve seu cv classificado como médio (14,58\%).

Na Figura 25, o gráfico apresenta uma comparação entre a quantidade de palhiço total presente na área, o palhiço úmido recolhido e o remanescente sobre o solo, bem como a Eficácia de Manipulação oriunda da relação entre elas. 


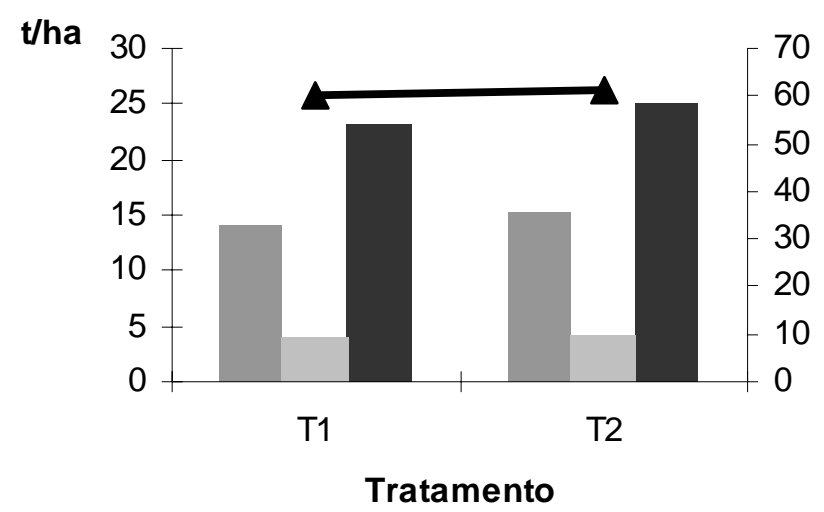

(\%)

PRecUT

PRemUT $\rightarrow$ EFM

Figura 25 - Comparação entre palhiço total, palhiço recolhido, palhiço remanescente e eficácia de manipulação para os tratamentos T1 e T2. $\mathrm{PRecUT}=$ palhiço recolhido úmido com terra; $\mathrm{PP}=$ produtividade do palhiço; PRemUT= palhiço remanescente úmido com terra; EFM= Eficácia de Manipulação

Na Figura 25 observa-se a similaridade entre a quantidade de palhiço total, a quantidade de palhiço recolhido, a quantidade de palhiço remanescente $\mathrm{e}$ a conseqüente eficácia de manipulação entre os dois tratamentos. Assim, as quantidades de palhiço total sobre o solo foram de 23,09 t.ha $^{-1}$ para o tratamento T1 e 25,18t.ha ${ }^{-1}$ para o tratamento T2. A Eficácia de Manipulação foi obtida pela razão entre o palhiço recolhido $\left(13,96\right.$ t.ha ${ }^{-1}$ no tratamento T1 e 15,24 t.ha ${ }^{-1}$ no tratamento T2) e o palhiço remanescente sobre o solo $\left(9,13\right.$ t.ha ${ }^{-1}$ no T1 e 9,93t.ha ${ }^{-1}$ no T2), apresentando valores bastante semelhantes entre si, diferindo apenas $0,60 \%$.

\subsubsection{Palhiço transportado por carga (úmido e seco)}

Um problema apresentado no recolhimento do palhiço para sua utilização na co-geração de energia é a baixa densidade deste material, que onera o processo, principalmente no transporte do campo até a usina. Assim, a 
quantidade de palhiço transportada em cada unidade de transporte (carga) tornase uma variável de interesse quando do cálculo dos custos da operação.

Na Figura 26 estão apresentados as médias de palhiço recolhido úmido com terra por carga e palhiço recolhido seco sem terra por carga de ambos os tratamentos.

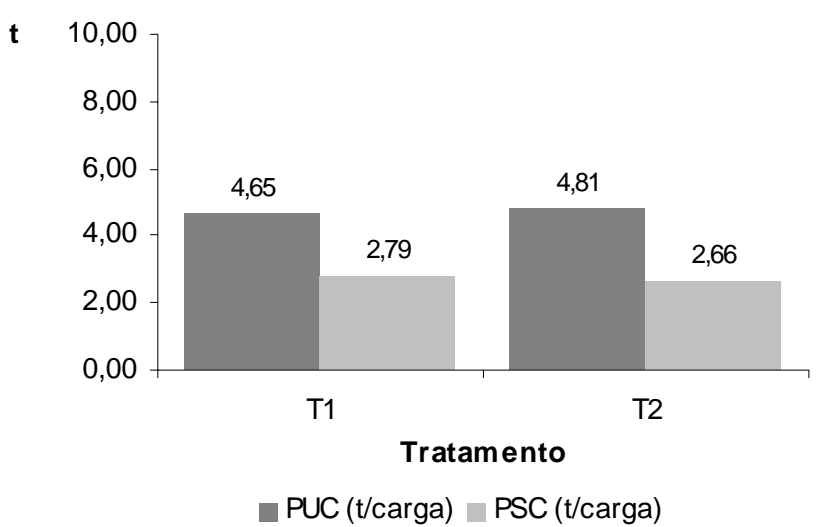

Figura 26 - Comparação entre palhiço recolhido úmido com terra por carga e palhiço recolhido seco sem terra por carga para tratamento T1 e T2. PUC= palhiço úmido na unidade de transporte; $\mathrm{PSC}=$ palhiço seco na unidade de transporte

Como é possível observar na Figura 26, as quantidades de palhiço recolhido em cada tratamento foram bastante próximas, tanto quando se fala em palhiço úmido com terra quanto palhiço seco sem terra. As médias encontradas para as duas variáveis para ambos os tratamentos não apresentaram diferenças significativas. Isto se deve ao fato da capacidade volumétrica dos dois caminhões utilizados no transporte do palhiço até a usina também ser semelhante $\left(50,14 \mathrm{~m}^{3}\right.$ e $54,57 \mathrm{~m}^{3}$ ), e as unidades de transporte foram utilizados nas repetições dos dois tratamentos de forma aleatória. A baixa densidade do palhiço leva a uma relativa pequena quantidade transportada até a usina em cada viagem, ou seja, a sub utilização dos veículos de transporte, o que acaba por encarecer o sistema de recolhimento de palhiço como um todo. Isto ficou ainda mais evidente quando, 
após o trajeto da área experimental até a usina, todas as cargas, apresentaram, nitidamente, a acomodação das partículas de palhiço durante a viagem (percurso de aproximadamente $17 \mathrm{~km}$ ), demonstrando haver espaço para mais palhiço (Apêndice 7). Tratando-se de palhiço seco, isto se torna ainda mais evidente, uma vez que em ambos os casos, cada carga possibilitou o transporte de menos de três toneladas de palhiço seco sem terra.

\subsubsection{Massa específica}

Para avaliar-se o transporte do palhiço recolhido até a usina, foram determinados também os valores obtidos de massa específica deste material. $\mathrm{Na}$ Figura 27, estão apresentados os histogramas onde a distribuição dos dados de massa específica de cada tratamento são separados em faixas.
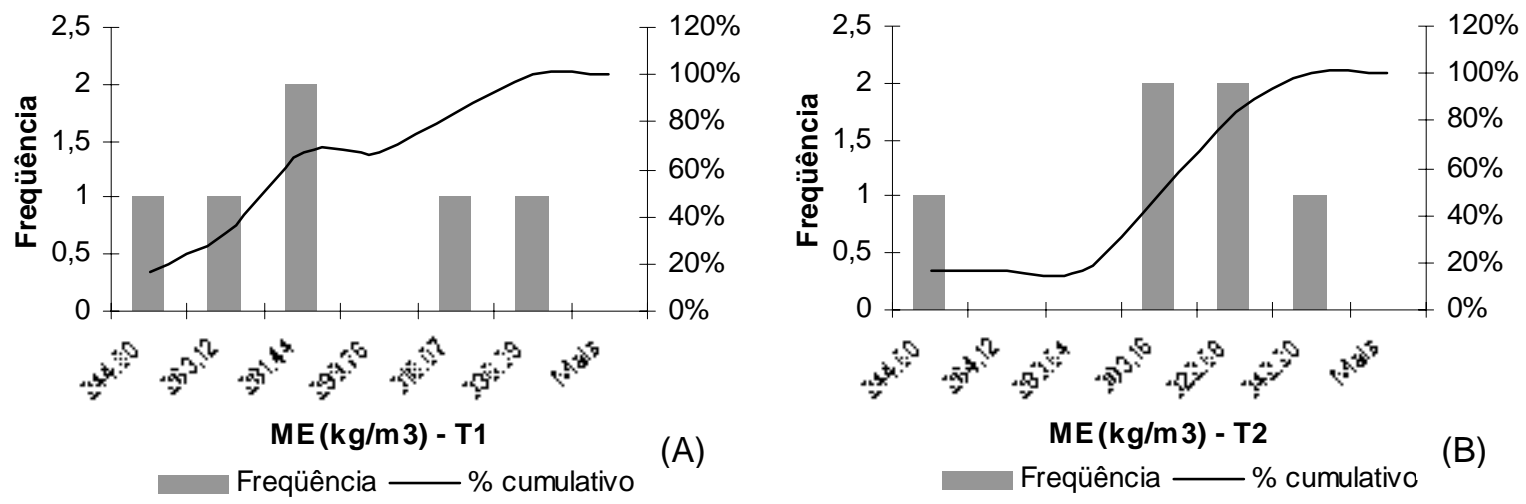

Figura 27 - Massa específica do palhiço $\left(\mathrm{kg} \cdot \mathrm{m}^{3}\right)$. (A) Tratamento T1. (B) Tratamento T2. ME= massa específica

O palhiço apresentou valores distintos para a variável massa específica do palhiço, com médias de $278,46 \mathrm{~kg} \cdot \mathrm{m}^{-3}$ e $304,04 \mathrm{~kg} \cdot \mathrm{m}^{-3}$, não ocorrendo, entretanto, diferenças significativas entre as médias. Os coeficientes de variação para ambos os tratamentos foram considerados médios, por se encontrarem na faixa de 10 a $20 \%$ (12,45\% para T1 e $10,47 \%$ para T2). O 
tratamento T1 apresentou assimetria positiva, enquanto que o tratamento T2 apresentou assimetria negativa.

Para ambos os tratamentos foi possível observar a existência de repetições com valores mais extremos, tanto para mais como para menos, o que demonstra irregularidade nesta variável. No tratamento T2, uma observação presente na faixa de menor valor tornou a média para este tratamento menor, enquanto que no tratamento $\mathrm{T} 1$, duas observações fizeram com que o valor da média fosse maior.

A importância desta variável reside na necessidade de avaliar-se o comportamento do palhiço transportado à granel dentro de cada carga. Assim, a baixa massa específica a existência de baixas quantidades de palhiço transportado em cada carga, devido aos chamados bolsões que se formam durante o carregamento. Com a agitação ocorrida durante o trajeto até a usina, o material tende a se acomodar, deixando espaços livres que poderia ter sido utilizados para carregar mais palhiço, como pode ser visualizado no Apêndice 7 .

\subsubsection{Energia}

A Figura 28 apresenta o gráfico referente a quantidade média de energia, em equivalente barril de petróleo (EBP) por hectare, disponível no palhiço recolhido em cada tratamento. 


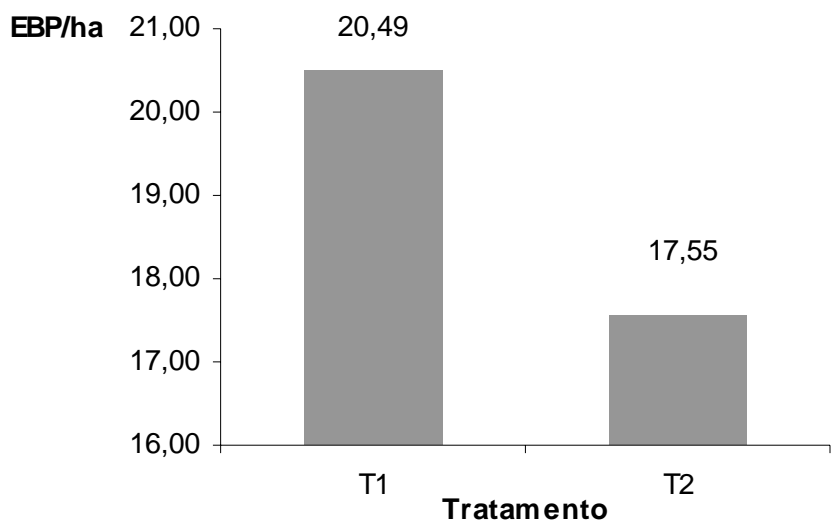

Figura 28 - Energia disponível no palhiço recolhido (EBP. $\left.\mathrm{t}^{-1}\right)$

\subsubsection{Custo de transporte $\left(\mathrm{R} \$ . \mathrm{t}^{-1}, \mathrm{R} \$ . E B P^{-1}\right)$}

Para o cálculo do custo do transporte do palhiço da área experimental até a usina, num percurso de, aproximadamente, $17 \mathrm{~km}$, foi utilizada a informação fornecida pela Usina Costa Pinto - Grupo COSAN, de que o custo por tonelada de palhiço descarregado foi de $R \$ 8,90$. Com base nesta informação, foram obtidos os valores apresentados na Tabela 18.

Tabela 18. Custo em R $\$ . \mathrm{EBP}^{-1}$, do transporte do palhiço

\begin{tabular}{rcc}
\hline Tratamentos & T1 & T2 \\
\hline Custos $\left(\mathrm{R} \$ . \mathrm{EBP}^{-1}\right)$ & 3,68 & 3,85 \\
\hline
\end{tabular}

Como é possível constatar, para ambos os tratamentos os valores foram próximos. Tendo em vista que ambos os tratamentos apresentaram o mesmo valor de custo em $\mathrm{R} \$ . \mathrm{t}^{-1}$, fornecido pelo Grupo COSAN - Costa Pinto, esta diferença existente entre os tratamentos foi originada pela maior umidade do palhiço no tratamento T2, afetando o poder calorífico útil do palhiço neste tratamento. 


\subsubsection{Custo de descarregamento}

O custo da operação de descarregamento do palhiço também foi fornecido pelo Grupo COSAN - Costa Pinto, com base em suas planilhas internas, calculados em 2,11R $\$ . \mathrm{t}^{-1}$. Após a transformação de $\mathrm{R} \$ . \mathrm{t}^{-1}$ em $\mathrm{R} \$ . E B P^{-1}$ foram obtidos os valores apresentados na Tabela 19.

Tabela 19. Custo em R\$.EBP ${ }^{-1}$, do descarregamento do palhiço

\begin{tabular}{lcc}
\hline Tratamentos & T1 & T2 \\
\hline Custos $\left(\mathrm{R} \$ . \mathrm{EBP}^{-1}\right)$ & 0,87 & 0,91 \\
\hline \multicolumn{2}{c}{ Pode-se notar que o tratamento T2 apresentou custo mais elevado do } \\
que o tratamento $\mathrm{T} 1$, provavelmente devido também a umidade presente no \\
palhiço modificando o poder calorífico útil, e a quantidade de palhiço transportado \\
por carga.
\end{tabular}

\subsubsection{Custo total do palhiço posto na usina}

Para o cálculo do custo total do palhiço posto na usina, foram considerados os custos da operação de enleiramento, recolhimento, transporte e descarregamento. Os dados utilizados neste cálculo estão apresentados na Tabela 20.

Tabela 20. Custo total do palhiço posto na usina, em três diferentes unidades

\begin{tabular}{lcccccc}
\hline \multicolumn{1}{c}{ Operações } & \multicolumn{3}{c}{$\mathrm{T} 1$} & & \multicolumn{3}{c}{$\mathrm{T} 2$} \\
& $\mathrm{R} \$ . \mathrm{t}^{-1}$ & $\mathrm{R} \$ . \mathrm{EBP}^{-1}$ & $\mathrm{R} \$ . \mathrm{ha}^{-1}$ & $\mathrm{R} \$ . \mathrm{t}^{-1}$ & $\mathrm{R} \$ . \mathrm{EBP}^{-1}$ & $\mathrm{R} \$ . \mathrm{ha}^{-1}$ \\
\hline Enleiramento & 1,20 & 0,49 & 27,71 & 0,49 & 0,23 & 12,34 \\
Recolhimento & 9,17 & 3,79 & 128,01 & 9,17 & 3,97 & 139,75 \\
Transporte & 8,90 & 3,68 & 41,34 & 8,90 & 3,85 & 42,77 \\
Descarregamento & 2,11 & 0,87 & 9,80 & 2,11 & 0,91 & 10,14 \\
Total & 21,38 & 8,83 & 206,87 & 20,67 & 8,97 & 205,00 \\
\hline
\end{tabular}


Como é possível observar, os custos totais para retirada do palhiço à granel nos dois tratamentos foram muito semelhantes, nas três unidades adotadas. O custo da operação de enleiramento foi muito maior no tratamento T1, mas nas outras etapas do processo esse custo foi diluído. Assim, em termos de custo, não houve diferença entre os tratamentos adotados, ou seja, para retirada do palhiço a granel do campo, pode-se adotar qualquer um dos dois enleiradores estudados.

Na Figura 29, estão confrontados os valores obtidos na bibliografia, em $\mathrm{R} \$ \mathrm{.}^{-1}$, para sistemas de enfardamento e recolhimento à granel do palhiço. Para que fosse possível a realização desta comparação, os valores obtidos nos trabalhos, apresentados em US\$ foram convertidos para reais, utilizando-se a cotação do dia 10 de setembro de 2003. 


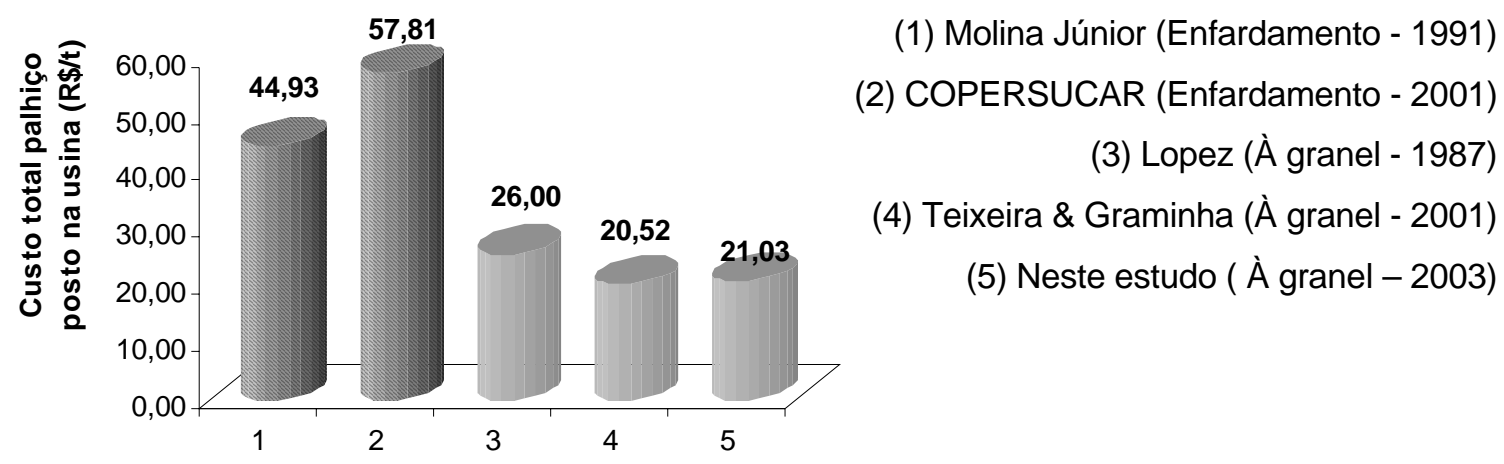

Figura 29 - Custo total do palhiço - comparação relativa entre diversos estudos

A confrontação dos dados obtidos em bibliografia mostra que o recolhimento à granel de palhiço de cana-de-açúcar, quando comparado ao sistema de enfardamento deste material, apresenta custos com médias variando entre $R \$ 20,52 \cdot t^{-1}$ e $R \$ 26,00 \cdot t^{-1}$. 


\subsection{Conclusões}

Com base nas informações extraídas da análise dos dados considerados neste capítulo, foi possível concluir que:

- Aceita-se a hipótese de trabalho, ou seja, o palhiço recolhido não sofreu influência significativa dos tipos de enleiradores utilizados. 


\section{CONCLUSÕES GERAIS}

Para a elaboração das conclusões gerais, foram consideradas as informações obtidas nos três capítulos deste estudo. Desta forma, foi possível concluir que:

- A utilização dos diferentes enleiradores não influenciou de maneira significativa as características do palhiço recolhido;

- A condição das leiras, em função de diferentes enleiradores não influenciou significativamente no desempenho operacional da recolhedora de forragens;

- O sistema de recolhimento à granel, sob o ponto de vista operacional, pode ser considerado como uma opção viável no manejo do palhiço de cana-de-açúcar, visando seu recolhimento e utilização na geração de energia. 


\section{REFERÊNCIAS BIBLIOGRÁFICAS}

ABRAMO FILHO, J.; MATSUOKA, S.; SPERANDIO,M.L. RODRIGUES,R.C.D.; MARCHETTI, L.L. Resíduo da colheita mecanizada de cana crua. Álcool \& Açúcar, v.67, n.2, p.23-5, 1993.

AGROPECUÁRIA AGORA. http://www.cna.org.br/agropecuariaagora (20 nov. 2002).

ANDRADE, L.A.B. de; CORREA, J.B.D; ANJOS, I.A. dos; FIGUEIREDO, P.A.M.; CARVALHO, G.J. Efeitos dos restos culturais da colheita de canade-açúcar com e sem queima prévia, na incidência de plantas infestantes e na produtividade da soqueira. STAB, Açúcar, Álcool e Subprodutos, v.18, n.1, p.34, set./out, 1999.

AREVALO, R.A.; BERTONCINI, E.I. Manejo químico de plantas daninhas nos resíduos de colheita de cana crua. STAB, Açúcar, Álcool e Subprodutos, v.17, n.4, p.36-38, mar./abr, 1999.

BANCO DE DADOS DE BIOMASSA NO BRASIL: Cana-de-açúcar no Brasil. http://www.infoener.iee.usp.br/cenbio/biomassa.htm, (12 out. 2002). 
BARTHOLOMEU, D.B.; SALVI, J.V.; ATALA JUNIOR, A.; ROCHA, M.T. Cogeração de energia a partir de bagaço de cana, 2001. http://www.cepea.esalq.usp.br/energ/zip/cogera\%e7ao\%20sober.pdf, out. 2002).

BRAUNBECK, O.A.; BANCHI, A.D. Carregamento mecânico - redução de impurezas minerais. Boletim Técnico COPERSUCAR, n.43, p.35-42, jul.1988.

BRITO, S.S. Energia de biomassa : uma alternativa para os trópicos. In: CONGRESSO PANAMERICANO DE ENERGIA , 3., Guatemala, 1986. Anais. São Paulo: CONFEA - CREA, 1986. p. 1-20.

BRITO, J.O.; BARRICHELLO, L.E.G. Aspectos técnicos na utilização de madeira e carvão vegetal como combustíveis. In: SEMINÁRIO DE ABASTECIMENTO ENERGÉTICO INDUSTRIAL COM RECURSOS FLORESTAIS, 2., São Paulo, 1982. Anais. São Paulo: Secretaria de Ciência e Tecnologia, 1982. p. 101-108.

BUZOLIN, P.R.S. Efeitos do palhiço residual da colheita mecanizada, associada a fontes de potássio e doses de nitrogênio no solo e nas socas de cana-deaçúcar. Jaboticabal, 1997. 98p. Dissertação (Mestrado) - Universidade Estadual Paulista "Júlio de Mesquita Filho".

CALDEIRA, D.S.A. Palhiço residual de cana-de-açúcar (Saccharum spp) colhida mecanicamente (sem queima prévia): manejo, fertilização, influência no perfilhamento e produtividade da cultura. Botucatu, 2002. 94p. Tese (Doutorado) Faculdade de Ciências Agronômicas, Universidade Estadual Paulista "Júlio de Mesquita Filho". 
CAMPOS, M.S.; MARCONATO, A. Sistema cana crua x cana queimada CLASS 2000. STAB, Açúcar, Álcool e Subprodutos, v.12, n.3, p.10-16, jan./fev,1994.

CARVALHO, G.J. de. Análise da potencialidade autoalelopática de restos culturais da colheita de cana-de-açúcar. Lavras, 1996. 72p. Tese (Doutorado) - Universidade Federal de Lavras.

CARVALHO FILHO, S. M. Colheita mecanizada: desempenho operacional e econômico em cana sem queima prévia. Piracicaba, 2000. 108p. Dissertação (Mestrado) - Escola Superior de Agricultura "Luiz de Queiroz", Universidade de São Paulo.

CHRISTOFFOLETI, P. J. Controle de plantas daninhas na cultura da cana-deaçúcar através de herbicida. In: CONGRESSO BRASILEIRO DA CIÊNCIA DAS PLANTAS DANINHAS, 21, Viçosa, 1997. Resumos. Viçosa: Sbpcd, 1997, p.253.

COELHO, S. T. Co-geração de eletricidade a partir de biomassa no setor industrial. http://www.ambienta.com.br/cenbio/biomassa/cogera.htm, (15 jul. 2002).

COPERSUCAR - PROJETO BRA/96/G31. Efeito agronômico do palhiço remanescente de canaviais colhidos mecanicamente sem a utilização da queimada. Cenbio Notícias, v.4, n.12, 2001. http://www.cenbio.org.br/index1.htm (15 jul. 2002).

COPERSUCAR - PROJETO BRA/96/G31. Disponibilidade de palha de cana. Cenbio Notícias, v. 3, n. 9. http://www.cenbio.org.br (15 jul. 2002). 
COPERSUCAR - Resumo dos testes de enfardamento. http://www.mct.gov.Br/clima/comunic old/bagaco07.htm (15 jul. 2002).

COSTA, M.C.G. Eficiência agronômica de fontes nitrogenadas na cultura da cana-de-açúcar sem despalha a fogo. Piracicaba, 2001. 79p. Dissertação (Mestrado em Solos e Nutrição de Plantas) - Escola Superior de Agricultura "Luiz de Queiroz", Universidade de São Paulo.

DEGASPARI, N. et al. A queima de cana-de-açúcar, os efeitos sobre a população da broca Diatraea Saccharalis (Fabr. 1794), seus predadores e parasitos. . STAB, Açúcar, Álcool e Subprodutos, v.1, n.5, p.35-40, mai/jun, 1983.

DE LEON, M.J. Avaliação de desempenho operacional de duas colhedoras em cana (Saccharum spp) crua. Piracicaba, 2000. 111p. Dissertação (Mestrado) - Escola Superior de Agricultura "Luiz de Queiroz", Universidade de São Paulo.

DE LUCA, E.F. Matéria orgânica e atributos do solo em sistemas de colheita com e sem queima da cana-de-açúcar. Piracicaba, 2002. 100p. Tese (Doutorado) - Escola Superior de Agricultura "Luiz de Queiroz", Universidade de São Paulo.

DOAT, J. Le pouvoir calorifique dês bois tropical. Bois et Forets dês Tropiques, v.172, p.33-55, Mar/Avr, 1977.

DUARTE, L.P.; MATTOS, Z.P.; NORONHA, J.F.; BALASTREIRE, L.A. Custo dos serviços de máquinas e implementos agrícolas. Piracicaba, ESALQ, Depto. Economia e Sociologia Rural, 1988. 32p. (Manual, 14). 
FACCENDA, O.; SOUZA. L.G. Desempenho em cogeração em uma indústria de processamento de cana. Engenharia Rural, v.9, n.1, p. 1-70. Julho/1998.

FNP CONSULTORIA \& COMÉRCIO. AGRIANUAL 2002: Anuário da agricultura brasileira, São Paulo, 2002. 536p.

FURLANI NETO, V.L.; RIPOLI, T.C.C.; VILLA NOVA, N.A. Avaliação de desempenho operacional em canaviais com e sem queima prévia. STAB, Açúcar, Álcool e Subprodutos, v.15, n.2, p.18-23, nov./dez, 1996.

GUEDES, S.N.R.; RÉ, R.M. Os determinantes da decisão microeconômica de mecanizar o corte da cana: um estudo de caso. http://www.unimep.br/fgn/economia/ecosober.html (07 jan. 2003).

GOMES, F.P. Curso de estatística experimental. Piracicaba: Nobel, 1990. $468 p$.

GOMIDE, M.B. Potencialidades alelopaticas dos restos culturais de dois cultivares de cana-de-açúcar (Saccharum $s p$ ), no controle de algumas plantas daninhas. Piracicaba, 1993. 96p. Tese (Doutorado) - Escola Superior de Agricultura "Luiz de Queiroz", Universidade de São Paulo.

IDEA NEWS. Ribeirão Preto, n.18, p. 4-9, março/2002.

KIEHL, E.J. Manual de edafologia. São Paulo: Agronômica Ceres, 1979, 264p.

LANÇAS, K.P. A evolução das alternativas energéticas com a crise do petróleo e a projeção da biomassa. Botucatu: UNESP, 1984. 34p. 
LEÃO, R.M. Álcool, energia verde. São Paulo: IQUAL - Instituto de Qualificação Editora Ltda. 2002. 255p.

LIMA, L.O.T.C. Com maior densidade. Idea News, n.19, p.28-31. abril/2002.

LOPEZ, P.A. Recolecion de barbojo como fuente energética en el Central Romana. In: Uso alternativo de la caña de azúcar para energia y alimento. México: GRUPO DE PAÍSES LATINOAMERICANOS Y DEL CARIBE EXPORTADORES DE AZÚCAR. 1987. p.57-62 (Colección GEPLACEA).

LORENZI, H. Considerações sobre plantas daninhas no plantio direto. In: TORRADO, P.V.; RAPHAEL, A.R. Plantio direto no Brasil. Campinas: Fundação Cargill, 1984. cap.2, p.13-46.

LORENZI, H. Tiririca. Uma séria ameaça aos canaviais. Boletim técnico COPERSUCAR, v.35, p.3-10, 1986.

LUCCHESI, A.A. Processos fisiológicos da cultura da cana-de-açúcar (Saccharum spp.). Boletim técnico ESALQ/CENA, n.7, 1995. p.1-50.

MEDEIROS, DANIEL; CHRISTOFFOLETI, Mecanização da colheita da cana traz benefício ambiental; máquinas dispensam queimadas e aumentam rendimento, mas têm desvantagens. Ciência Hoje. http://www.uol.com.br/cienciahoje/chdia/n593.htm (10 jan. 2003).

MIALHE, L.G. Manual de mecanização agrícola. São Paulo: Agronômica Ceres, 1974. 301p. 
MIRANDA, L.L.D. Informativo Copercana - Canaoeste - Cocred. Edição n.1 maio/2000. http://www.florestasite.com.br/cana.htm (15 jul. 2002).

MOLINA JUNIOR, W.F.; RIPOLI, T.C.; COELHO, J.L.D.; AMARAL, J.R.; SACOMANO, J.B. Estudo preliminar sobre enfardamento de resíduos de colheita de cana-de-açúcar (Saccharum spp.). In: CONGRESSO BRASILEIRO DE ENGENHARIA AGRÍCOLA, 20., Londrina, 1991, Resumos. Londrina: SBEA, 1991. p.26.

MOLINA JUNIOR., W.F.; RIPOTI, T.C.C.; GERALDI, R.N.; AMARAL, J.R. Aspectos econômicos e operacionais do enfardamento de resíduos de colheita de cana-de-açúcar para aproveitamento energético. STAB, Açúcar, Álcool e Subprodutos, v.13, n.5, p.28-31, mai./jun, 1995.

NASCIMENTO, A.F. do. Efeitos da pré-fertilização potássica na produção de mudas de duas variedades de cana-de-açúcar. Viçosa, 1999. 37p. Dissertação (Mestrado) - Universidade Federal de Viçosa.

NERY, M.S. Desempenhos operacional e econômico de uma colhedora em cana crua. Piracicaba, 2000. 108p. Dissertação (Mestrado) - Escola Superior de Agricultura "Luiz de Queiroz", Universidade de São Paulo.

ORLANDO FILHO, J.; ZAMBELLO JUNIOR, E.; AGUJARO, R.; ROSSETO, A.J. Efeito do sistema de despalha (cana crua $x$ cana queimada) sobre algumas propriedades do solo. STAB, Açúcar, Álcool e Subprodutos, v.16, n.6, p.30-33, jul./ago, 1998.

PAGNANO, N.B. Despalhador inercial de facas oscilantes para cana-de-açúcar (Saccharum spp.). Campinas, 1997. 78p. Dissertação (Mestrado) Universidade Estadual de Campinas. 
PATUSCO, J.A.M. Biomassa e geração elétrica. Coordenadoria-Geral de Estudos Integrados MME/Brasil. 2002. http://ecen.com/content/eee5/biomas.htm (04 out. 2002).

QUINTELA, A.C.R. Controle de plantas daninhas e rendimentos de cana crua, no sistema integrado palhiço, herbicida e vinhaça. Lavras, 2001. 75p. Tese (Doutorado) - Universidade Federal de Lavras.

REVISTA GLEBA - INFORMATIVO TÉCNICO. Cana-de-açúcar: proteger o ambiente e continuar gerando empregos. Edição Setembro 2001. http://www.cna.org.br/gleba99n/set01/cana01.htm (05 out. 2002).

RIPOLI, T.C.C. Utilização do material remanescente de colheita de cana-deaçúcar (Saccharum spp) - Equacionamento dos balanços energético e econômico. Piracicaba, 1991. 150p. Tese (Livre-Docência) - Escola Superior de Agricultura "Luiz de Queiroz", Universidade de São Paulo.

RIPOLI, T.C.C. Ensaios e certificação de máquinas para colheita de cana-deaçúcar. IN: MIALHE, L.G. Máquinas Agrícolas: ensaios e certificação. Piracicaba: Fundação de Estudos Agrários Luiz de Queiroz, 1996, cap. 13, p. 635-674: Ensaios e certificação de máquinas para colheita de cana-deaçúcar.

RIPOLI, T.C.C. Viabilidade técnico-econômica da coleta e transporte do palhiço para produção de energia elétrica (um projeto para recolhimento do palhiço). Compact disc. In: SEMINÁRIO DE MECANIZAÇÃO E PRODUÇÃO DE CANA-DE-AÇÚCAR, 4. Ribeirão Preto, 2002. Resumos. Ribeirão Preto: IDEA, Ribeirão Preto, $2002^{\mathrm{a}}$. 
RIPOLI, M.L.C. Mapeamento do palhiço enfardado de cana-de-açúcar (Saccharum spp) e do seu potencial energético. Piracicaba, 2002. 91p. Dissertação (Mestrado) - Escola Superior de Agricultura "Luiz de Queiroz", Universidade de São Paulo.

RIPOLI, T.C.C.; MIALHE, L.G. Colheita manual vs. colheita mecanizada de cana-de-açúcar. STAB, Açúcar, Álcool e Subprodutos, v.5, n.3, p.27-37, jan./fev, 1987.

RIPOLI, T.C.C.; VILLA NOVA, N.A. Colheita mecanizada da cana-de-açúcar: novos desafios. STAB, Açúcar, Álcool e Subprodutos, v.11, n.1, p.28-31, set./out, 1992.

RIPOLI, M.L.C.; RIPOLI, T.C.C. Caracterização dos principais constituintes da biomassa de cana-de-açúcar (Saccharum spp). In: SIMPÓSIO DE INICIAÇÃO CIENTÍFICA DA UNIVERSIDADE DE SÃO PAULO, 4., São Paulo, 1995. Resumos. Piracicaba: Ed.EDUSP, 1996. v.1, p.463.

RIPOLI, T.C.C.; MIALHE, L.G.; BRITO, J.O. Queima de canavial: o desperdício não mais admissível! Álcool \& Açúcar, v.10, n.54, p.18-23, jul./ago. 1990.

RIPOLI, T.C.C; TILLMAN, C.A. de C.; MILAN, M.O. O corte manual da cana verde. Álcool e Açúcar, v.77, p.28-30, 1995.

RIPOLI, T.C.C.; BALASTREIRE, L.A.; MOLIN, J.P.; MOLINA JUNIOR, W.F. Sugar cana biomass energy in Brazil. In: INTERNATIONAL CONGRESS ON AGRICULTURAL ENGINEERING, 13, Morocco, 1998. Anais. Morocco: ICAE, 1998. v.4, p.51-57. 
RIPOLI, M.L.C.; RIPOLI, T.C.C.; GAMERO, C.A. Colheita integral: retrocesso ou barateamento do sistema? IDEA NEWS, V. 4, n. 28, p.66-67, jan./2003.

RIPOLI, T.C.C.; RIPOLI, M.L.C.; CASAGRANDI, D.V. In: Encontros FERMENTEC: Reunião Agrícola, 8, São Pedro, 2003. Anais. Piracicaba: FERMENTEC. $1 \mathrm{~cd}$.

SANTAELLA, M. Um modelo de avaliação de novas tecnologia: o caso do sistema de cana crua. Piracicaba: 1995. 89p. Dissertação (Mestrado) Escola Superior de Agricultura "Luiz de Queiroz", Universidade de São Paulo.

SARRIÉS, G.A. Controle estatístico da qualidade para impurezas minerais em carregamentos de cana-de-açúcar. Piracicaba: 1997. 88p. Tese (Doutorado) Centro de Energia Nuclear na Agricultura, Universidade de São Paulo.

SARTORI, M.M.P. Otimização da produção de energia e biomassa do resíduo de colheita em variedades de cana-de-açúcar. Botucatu, 2001. Tese (Doutorado) Faculdade de Ciências Agronômicas, Universidade Estadual Paulista "Julio de Mesquita Filho".

SPIEGEL, M.R. Estatística. São Paulo: McGraw-Hill, 1974. 580p.

STOUT, B.A. Another alternative: energy from agriculture. In: STOUT, B.A. Energy use and management in agriculture. New York: Breton, 1984. p.169-244. 
SUGUITANI, C.; GHELLER, A.C.A.; MENEGHIN, S.P. Efeitos do sistema de colheita da cana-de-açúcar na biomassa microbiana do solo. Compact Disc . Congresso de Iniciação Científica da UFSCAR, 7. Resumos. São Carlos: Universidade Federal de São Carlos. 2001.

TIMM, L.C. Efeito do manejo da palhiço da cana-de-açúcar nas propriedades físico-hídricas de um solo. Piracicaba, 2002. 115p. Tese (Doutorado) Escola Superior de Agricultura "Luiz de Queiroz", Universidade de São Paulo.

TORRESAN, H.F. Enleiramento e enfardamento prismático de palhiço de canade-açúcar: alguns parâmetros de desempenho operacional e eficiência energética. Piracicaba, 2003. 88p. Dissertação (Mestrado), Escola Superior de Agricultura Luiz de Queiroz, Universidade de São Paulo.

UNIÃO DA AGROINDÚSTRIA CANAVIEIRA DE SÃO PAULO - UNICA. 2002. http.://www.unica.com.br/pages/estatísticas.asp (14 jan. 2003).

URQUIAGA, S.; RESENDE, A.S.; ALVES, B.J.R.; OLIVEIRA, O.C.; BODDEY, R.M. Queima de cana. Revista Agrobiologia - EMBRAPA, n.5, p.2, abril/1997. p. 17-28.

VEIGA FILHO, A.de A.; SANTOS, Z.A.P.; VEIGA, J.E.R.; OTANI, M.N.; YOSHI, R.J. Estimativa de desempenho na colheita de cana decorrente de mecanização. STAB, Açúcar, Álcool e Subprodutos, v.13, n.4, p.19-21, mar./abr, 1995. 


\section{APÊNDICES}


APÊNDICE 1. Palhiço existente na área experimental.
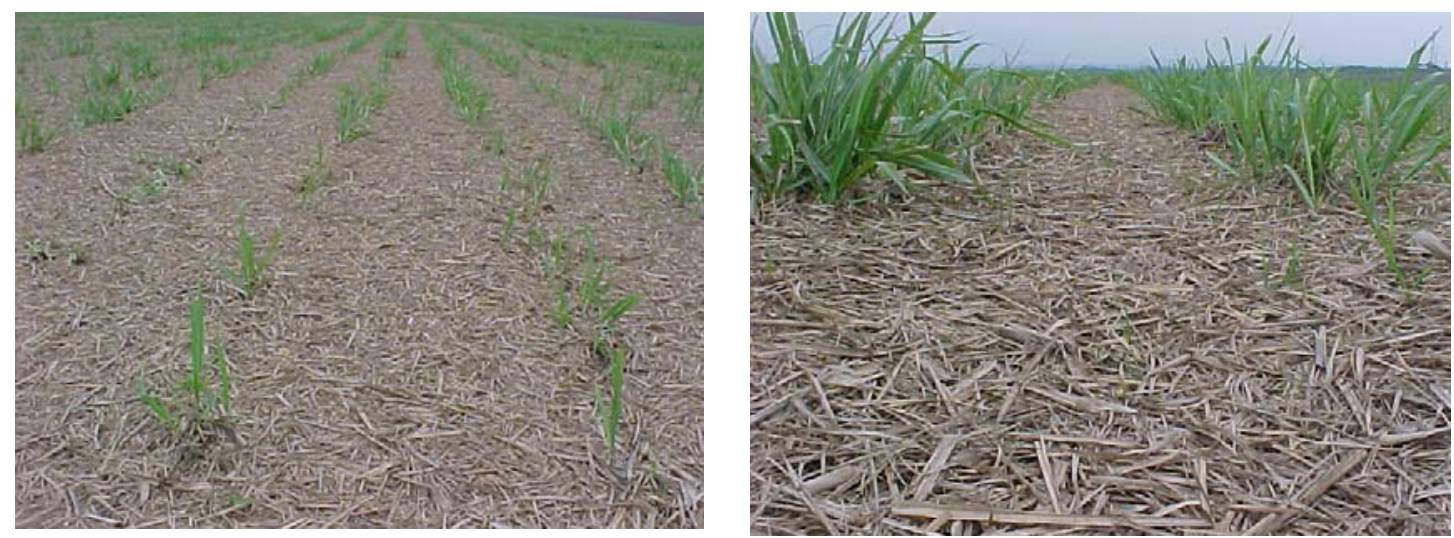

APÊNDICE 2. Enleiradores utilizados. (A) Enleirador DMB. (B) Enleirador John Deere.
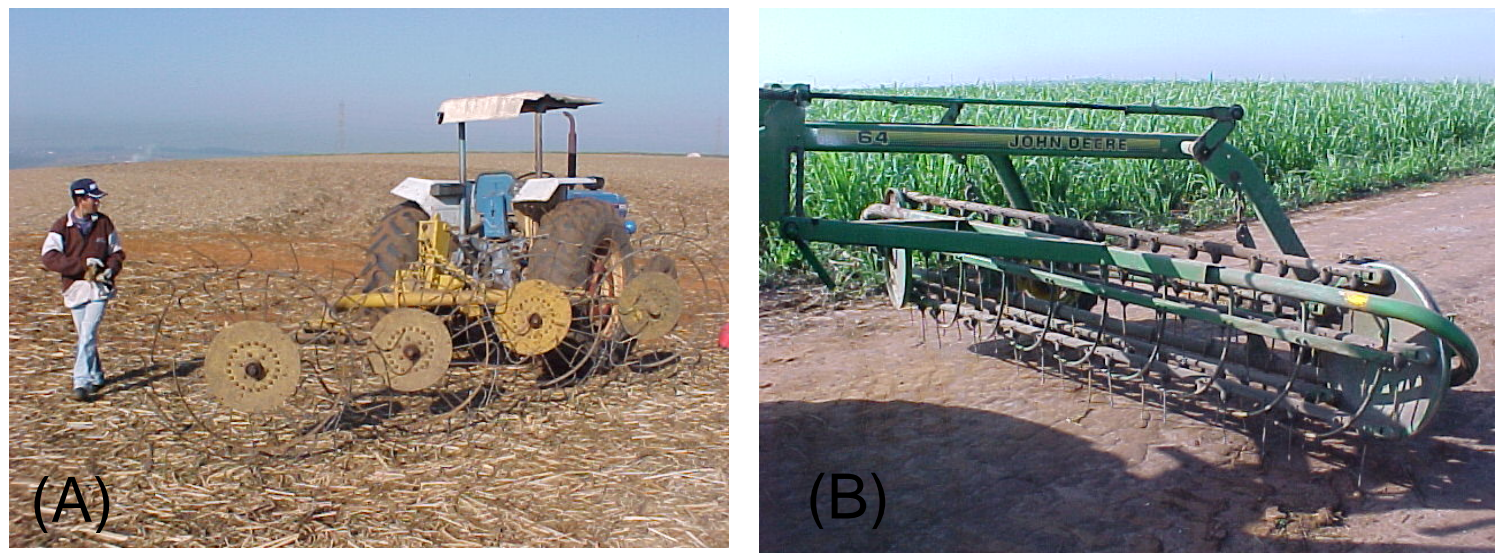
APÊNDICE 3. Operação de enleiramento. (A) Enleirador DMB. (B) Enleirador John Deere.
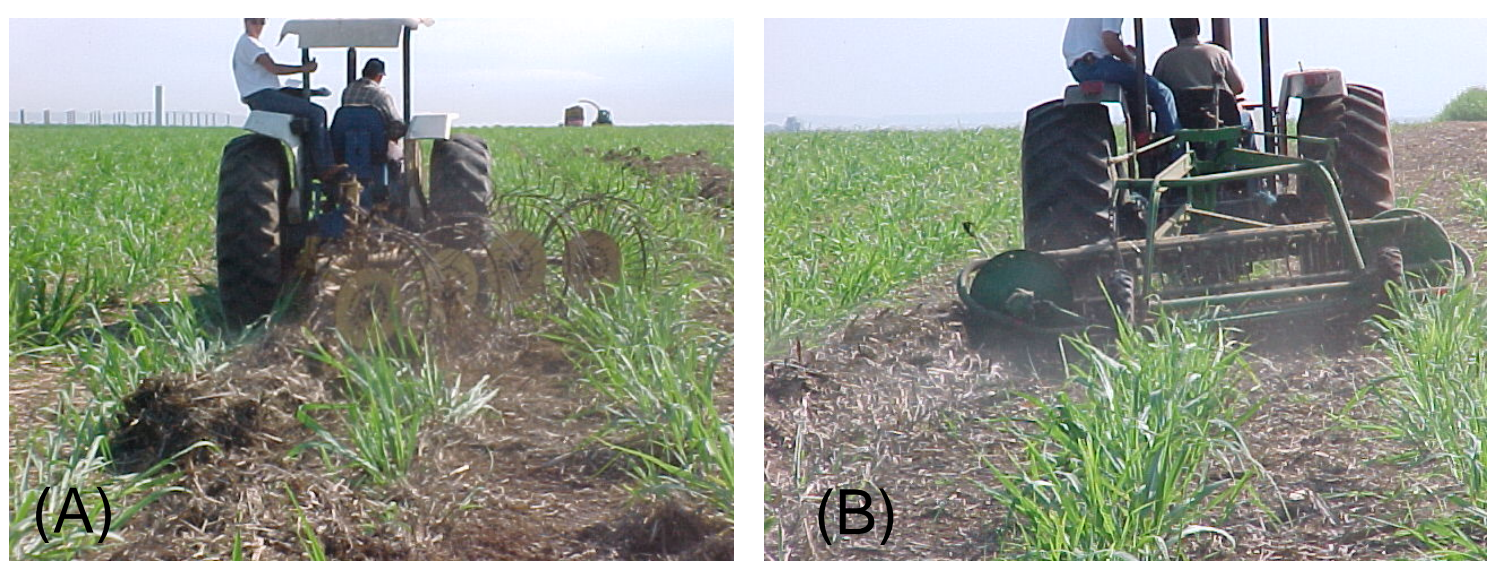

Apêndice 4. Recolhedora de forragens John Deere. (A) Operação de recolhimento; (B) Vista frontal da plataforma de recolhimento.
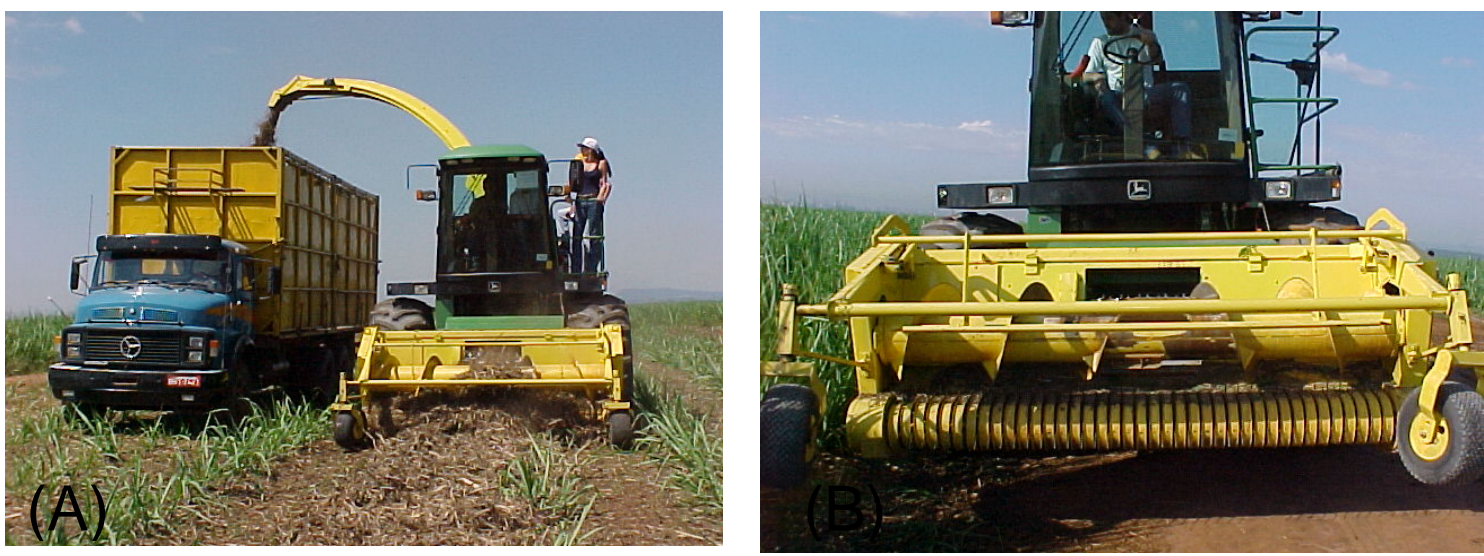
APÊNDICE 5. (A) Coleta de amostras de perdas; (B) Gabarito para coleta de amostras.
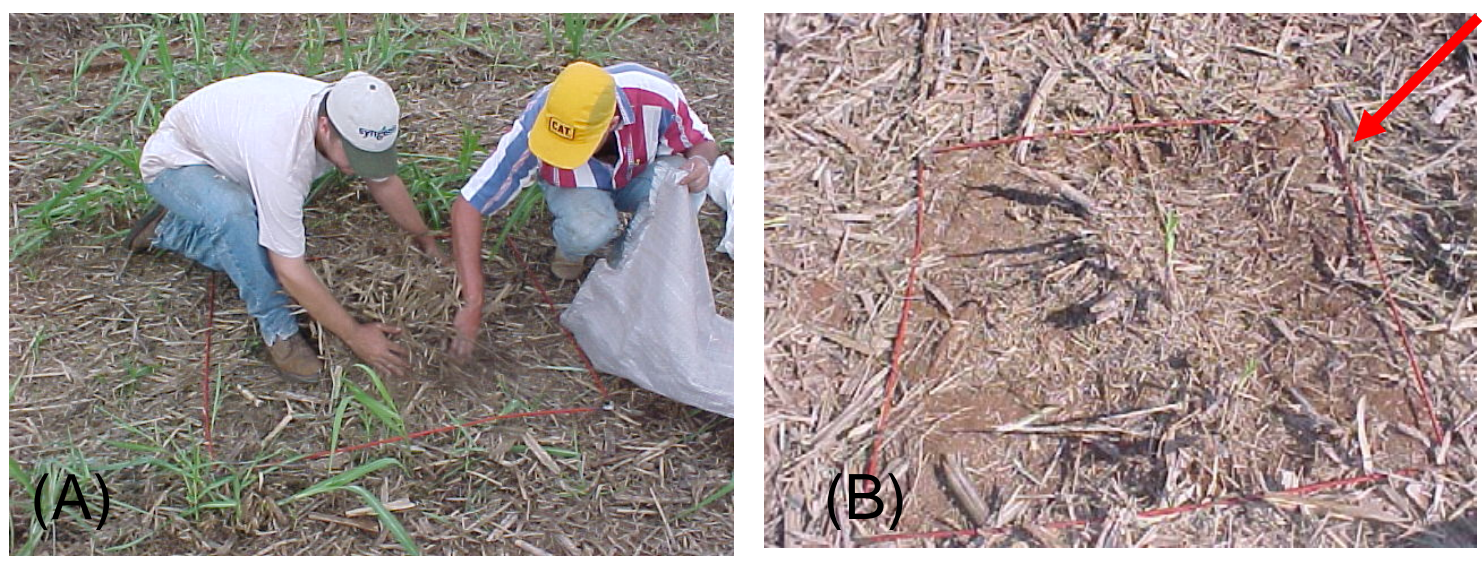

APÊNDICE 6. (A) Carga de palhiço; (B) Coleta das amostras de palhiço nas cargas.
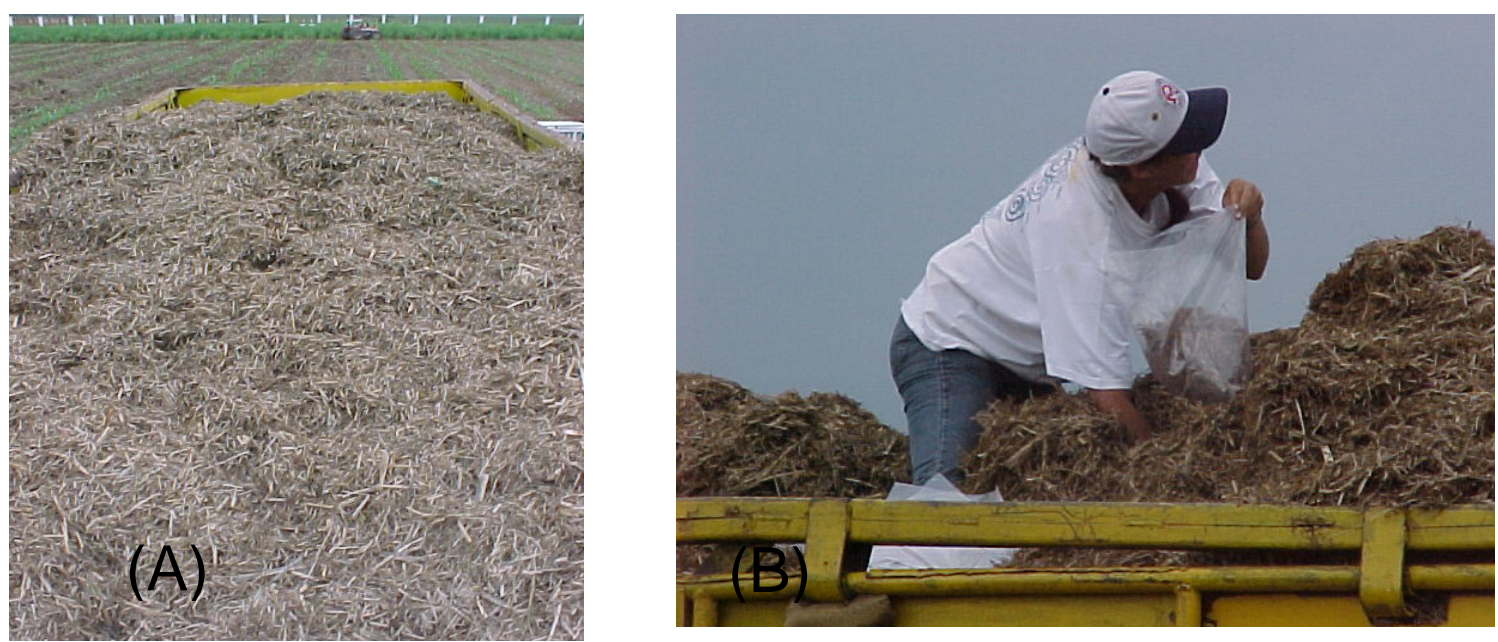
APÊNDICE 7. Carga de palhiço na área experimental e vista lateral da carga de palhiço antes do descarregamento, no pátio da usina.
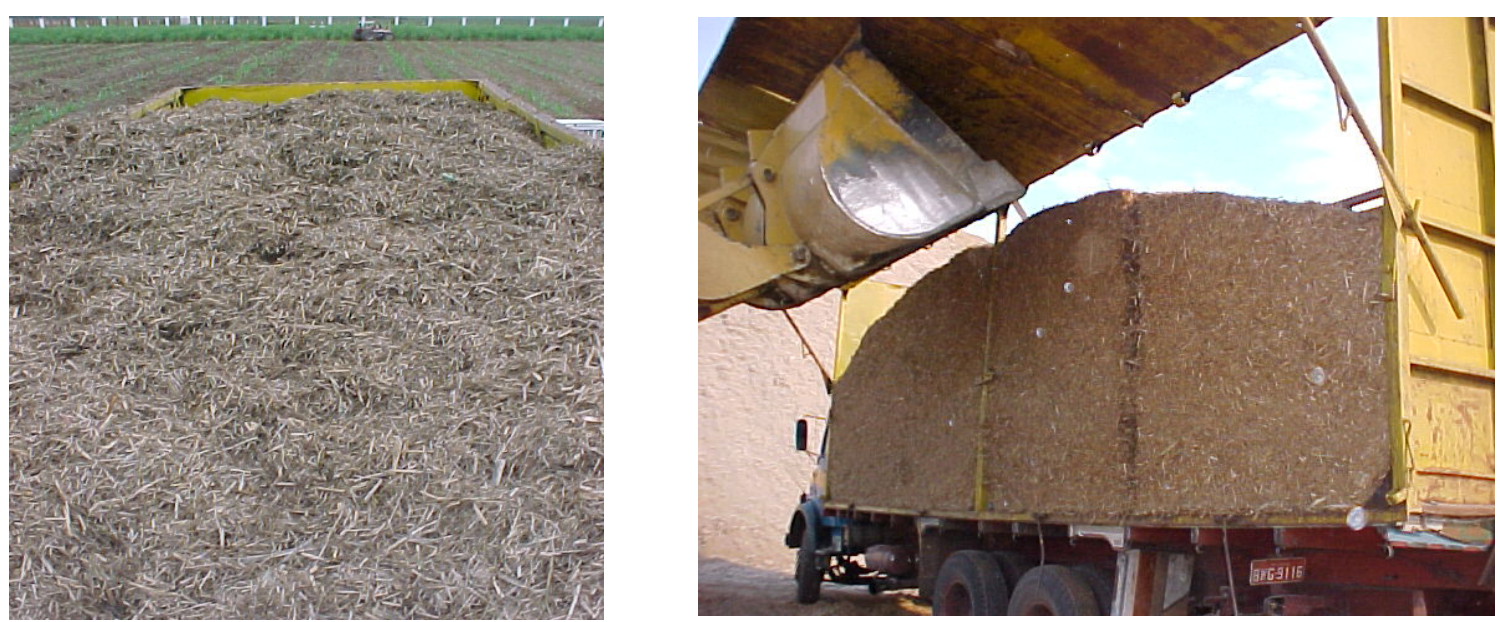